\title{
ARCHEOLOGIE STŘEDOVĚKU V PRAZE MEZI DVĚMA SVĚTOVÝMI VÁLKAMI - ZAPOMENUTÉ KAPITOLY Z HISTORIE OBORU
}

\author{
IVANA BOHÁČOVÁ - JAROSLAV PODLISKA
}

\begin{abstract}
Abstrakt: Studie je věnována počátečnímu obdobi rozvoje archeologie středověku v hlavním městě Praze, pro niž se vytvoŕlly z řady př́čin optimálni podmínky po vzniku Československa v roce 1918. Text rekapituluje základní principy koncepce a organizace archeologického výzkumu v rámci šíreji pojaté péče o kulturní památky města. Zaměruje se na dosud zcela neznámé kapitoly z historie tohoto oboru a jejich kličové aktéry, jejichž role byla patrně vzhledem k následnému společenskému vývoji v podstatě zapomenuta. Text se zabývá i tématy, z nichž mnohá se stala východiskem dnešního studia minulosti Prahy. Pozornost je rovněž věnována kompetencím jednotlivých institucí, zejména ale otázkám metod terénního výzkumu a jeho dokumentace.
\end{abstract}

Klíčová slova: Praha - archeologie středověku-památková péče - 20. století - historie oboru.

Archaeology of the Middle Ages in Prague between the wars: forgotten chapters from the history of the discipline

\begin{abstract}
This study is devoted to the beginnings of the development of archaeology of the Middle Ages in the capital city of Prague. For numerous reasons, the ideal conditions for this field emerged after the establishment of Czechoslovakia in 1918. The text sums up the basic principles of the concept and organisation of archaeological research within the more broadly approached care for cultural monuments in the city. It focuses on completely unknown chapters from the history of the discipline and its key protagonists whose role was basically forgotten, possibly owing to the subsequent social development. The article discusses subjects many of which have become points of departure for today's study of Prague's history. Attention is also devoted to the competences of the individual institutions and, in particular, to the methods of field survey and its documentation.
\end{abstract}

Key words: Prague - archaeology of the Middle Ages - heritage care-20th century-history of the discipline.

\section{1 Úvod}

Tématu pražské archeologie středověku mezi dvěma světovými válkami nebyla zatím věnována patřičná pozornost, ačkoliv jde o období, v němž proběhla v historickém jádru města řada klíčových výzkumů (obr. 1). Část poznatků se sice dočkala dřive nebo později více či častěji méně podrobného zveřejnění, podstatná část výzkumů nebyla ale dosud vyhodnocena. Odborné veřejnosti nejsou v řadě př́ipadů známy podrobněji okolnosti, za kterých akce probíhaly, dostupná mnohdy není jejich základní dokumentace, která zůstala roztroušená po různých institucích, stejně tak jako vlastní movité nálezy. Jen minimum informací máme nejen o koncepci tehdejší pražské archeologie, ale i o používaných metodách. Př́íspěvek se zaměřuje na některé z významných aspektů této etapy, kterou vnímáme jako počátek moderní archeologie středověku v Čechách obecně, a na některé $\mathrm{z}$ aktérů, jejichž role a prínos $\mathrm{v}$ této oblasti zůstaly takřka zapomenuty a nejsou v dostatečném rozsahu v povědomí odborné veřejnosti.

Postavení pražské archeologie $\mathrm{v}$ meziválečném období v rámci nově budované státní koncepce péče o památky a její charakteristice se nedávno poprvé věnovala I. Boháčová, která současně představila i existující archivní zdroje vztahující se k této problematice (2019). Základní přehled jednotlivých aktérů i míst děje pak zpracovali I. Boháčová a J. Podliska (2020). 


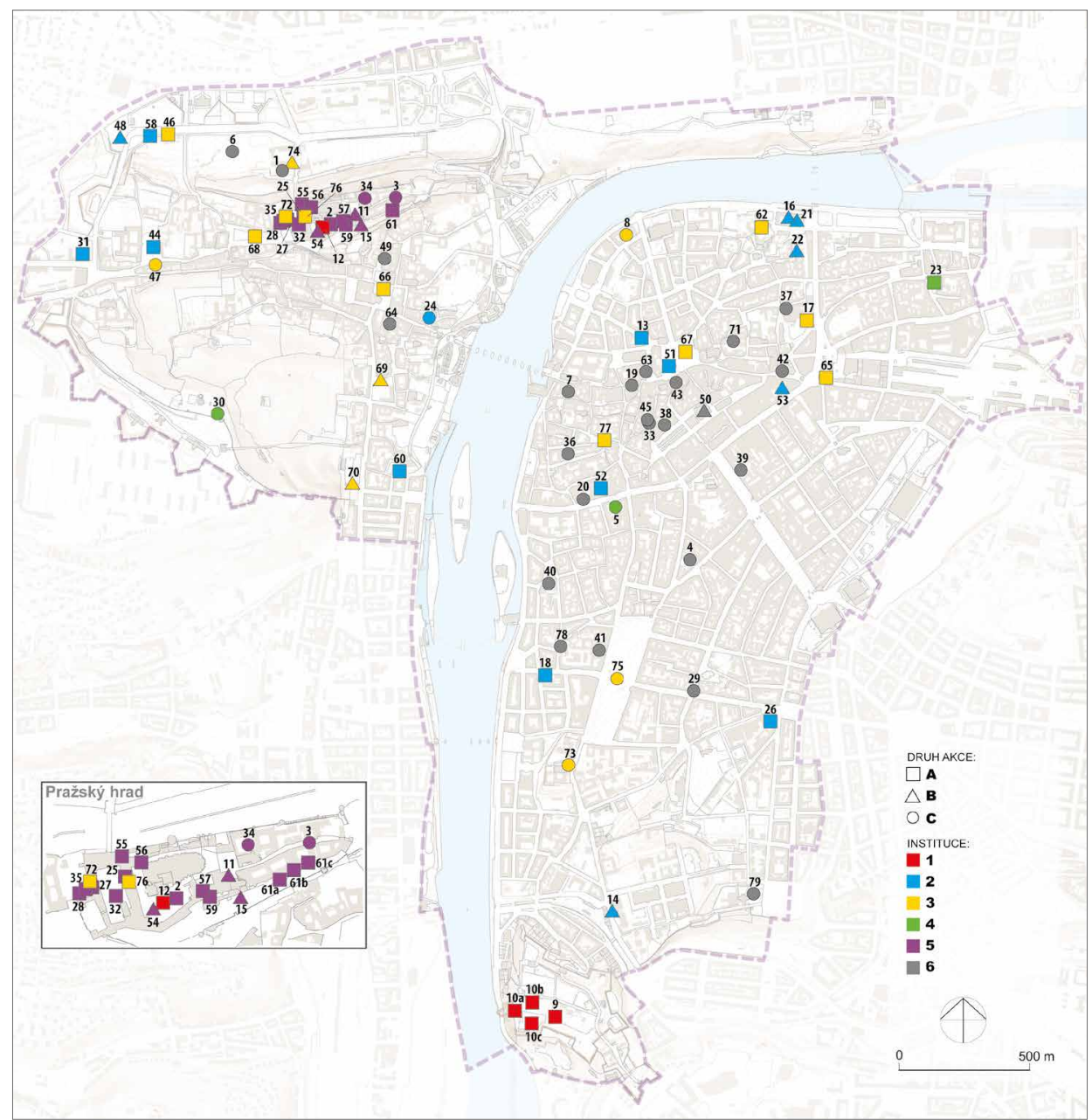

Obr. 1. Schematizovaný přehled archeologických aktivit a archeologických nálezů získaných v souvislosti se stavební činností v historickém jádru Prahy v hranicích Pražské památkové rezervace (1920-1948). Oproti databázi ADB (Hrdlička 2005; 2009) doplněno o dříve neevidovanou činnost Památkového sboru hl. města Prahy. V některých př́ípadech nelze zjištěnou aktivitu přiřadit jednoznačně ke konkrétní instituci. Další informace viz tab. 1. Lokalizace dle revidované mapy ADB (2019) a archivní dokumentace k činnosti Památkového sboru (ÚDU AV ČR, fond Hlubinka; AMP, MHMP, fond Památkový sbor). A - sonda nebo plocha; B - dohled, orientační zjištění; C - náhodný nález, nejasné; 1 - týmový, komisionálně vedený meziinstitucionální výzkum; 2 - Památkový sbor hl. města Prahy; 3 - StAÚ, 4 - jiné (NM, MMP, ÚDU FF UK); 5 - v gesci KPR; 6 - nejasné, neurčeno. Mapový podklad $\odot$ Institut plánování a rozvoje hl. města Prahy. Podle podkladu I. Boháčové graficky zpracovala S. Babušková.

Abb. 1. Schematisierte Übersicht der archäologischen Aktivitäten und im Zusammenhang mit Bautätigkeiten im Historischen Stadtkern Prags innerhalb der Grenzen des Prager Denkmalreservats gemachten archäologischen Funde (1920-1948). Gegenüber der ADB-Datenbank (Hrdlička 2005; 2009) um die früher nicht erfasste Tätigkeit des Denkmalbeirats der Hauptstadt Prag ergänzt. In einigen Fällen kann die festgestellte Aktivität nicht eindeutig einer konkreten Institution zugeordnet werden. Weitere Informationen siehe Tab. 1. Lokalisierung gemäß revidierter ADB-Karte (2019) und Archivdokumentation zur Tätigkeit des Denkmalbeirats (ÚDU AV ČR, Bestand Hlubinka; AMP, MHMP, Bestand Denkmalbeirat). A - Sondierschnitt oder Fläche; B - Überwachung, grobe Ermittlung; C - Zufallsfund, unklar; 1 - in Teamarbeit erfolgte und kommissionell geleitete institutionsübergreifende Grabung; 2 - Denkmalbeirat der Hauptstadt Prag; 3 - StAÚ, 4 - andere (NM, MMP, ÚDU FF UK); 5 - unter der Schirmherrschaft der KPR; 6 - unklar, unbestimmt. Kartenunterlage $\odot$ Planungs- und Entwicklungsinstitut der Hauptstadt Prag. Nach I. Boháčovás Unterlagen graphisch bearbeitet von S. Babušková. 


\section{Organizace a základní principy historické archeologie v Praze a jejím blízkém okolí v letech 1920-1939}

\subsection{Odborné instituce, míra a forma jejich zapojení}

Po vzniku republiky bylo historické jádro Prahy vystaveno početným stavebním zásahům v souvislosti s budováním nových veřejných staveb pro potřeby státní i městské správy. V prvních letech existence Československa byl zájem o českou minulost zcela mimořádný. Jeho vzestup byl podtržen stále ještě živým obrazem důsledků pokračující asanace částí historického centra města (Bečková 1993). Intenzivní stavební činnost znamenala další možné ohrožení středověkých památek Prahy, považované za jednu z prvořadých evropských metropolí stř̌edověku. Toto ohrožení podnítilo snahu odborné veřejnosti i př́slušných institucí nejen o zajištění náležité dokumentace pražských historických objektů a terénů, ale také o vytvoření památkového systému směřujícího $\mathrm{k}$ jejich případné ochraně. Současně vyústilo i ve formulaci obecných zásad péče o kulturní dědictví minulosti. Za jeho přirozenou a podstatnou součást byly považovány právě archeologické prameny. Tyto snahy byly všestranně podporovány Ministerstvem školství a národní osvěty (MŠANO) zvláště v osobě Z. Wirtha (na pozici ,sekčního šéfa“), který byl zodpovědný za oblast památek na území nově vzniklého státu. $Z$ jednání vyvolaného MŠANO k této problematice vznikla společná dohoda, na jejímž základě každá z odborných institucí zajištovala specifickou fázi procesu hospodaření s archeologickým dědictvím (Boháčová 2019, 287).

Státní archeologický ústav (StAÚ) jakožto instituce, jejímž hlavním posláním byla formulace a posléze realizace celostátní koncepce archeologického studia, měl garantovat kvalitu prováděných výzkumů a byl odpovědný za jejich evidenci. Státní památkový úřad (SPÚ) měl zabezpečit ochranu památek, současně ale spolurozhodoval se StAÚ o realizaci archeologických výzkumů. Podmínky pro ně byly ovšem více než skrovné jak z hlediska personálního, tak finančního zajištění. V Praze se situace nijak nevymykala možnostem ostatních regionů. Tato skutečnost mnohonásobně platí pro archeologii středověku, která si jen velmi pomalu budovala $\mathrm{v}$ rámci archeologie své pevné místo. V agendě nově vzniklého Státního archeologického ústavu se pro prvá léta po jeho založení objevují především písemnosti věnující se programu výzkumů na Moravě a ve Slezsku a na Slovensku; pokud jde o středověké výzkumy v Čechách, hovoří se pouze o výzkumech „,hradištni kultury zejména doby nejstarši i", a to včetně Pražského hradu a Vyšehradu, dále Ostrova u Davle a Budče. Na výzkum poněkud mladších archeologických památek se StAÚ více soustředil až v období po druhé světové válce (MÚA, fond 27, kart. 6). Národní muzeum mělo $v$ té době jako jediná instituce $\mathrm{k}$ dispozici již renomovaného odborníka se zaměřením a zejména s mimořádným zájmem o starší stř̌edověké památky, Karla Gutha. V Národním (původně Zemském) muzeu K. Guth působil od roku 1917, přitom v letech 1926-1942 zastával funkci přednosty historicko-archeologického oddělení. V rámci archeologického výzkumu Prahy a jejího blízkého okolí zaujal mimořádné postavení v čele meziinstitucionálních komisí pověřených vedením výzkumu (zvláště Pražský hrad, 3. nádvoří, zčásti Vyšehrad, Ostrov u Davle). Díky autoritě, kterou K. Guth v odborných kruzích požíval, byly výsledky těchto výzkumů spojovány především s jeho osobou a přirozeně se tak mohl ujmout jejich - i když pouze rámcového - vyhodnocení (Guth 1934). Teprve jeho předčasná smrt (1943) umožnila dalšímu z aktérů meziválečného výzkumu Prahy - I. Borkovskému - na práci K. Gutha navázat. Do terénního výzkumu historických památek v Praze naopak téměř nevstupovalo Muzeum hlavního města Prahy (MMP), jehož zájem se tradičně soustředil především na výzkum pravěkých lokalit a jehož angažmá bylo zejména mimo historické centrum. Na jeho bedrech však spočívala péče o získaný archeologický fond (k postavení MMP viz AMP, Magistrát hl. města Prahy, fond Památkový sbor, kart. 17, inv. č. 30; Hlava-Kostka 2014).

Obecně platnou situaci dobře ilustruje, pokud jde o kapacity oboru, př́́klad StAÚ, kde musel být nedostatek kvalifikovaných pracovníků ve 20. i 30. letech 20. století řešen zapojováním tzv. volontérů bez prŕslušného absolutoria (administrativa, konzervační práce, ,prrimý“ dozor nad 
terénním výzkumem). Ačkoliv jejich př́inos zvláště pro terénní výzkum byl v dané situaci zásadní a byl i vysoce hodnocen, nebyla jejich pozice, a to ani po ukončení vysokoškolského studia oficiálně uznávána jako odborná a nebyli kmenovými zaměstnanci př́slušných institucí. Jasně to popisuje ve IV. zprávě o činnosti StAÚ za rok 1923 jeho ředitel K. Buchtela: „V personálním stavu Ústavu nastala změna jenom potud, že podepsaný reditel, nemoha se domoci mista asistentského, a obsaditi je silou, která by se úplně zapracovala do potřeb a agendy Ústavu, nucen byl přibrati několik volontérů, jejichž remunerace hradil z úspor ušetřených na fondu výkopném. Těmito remunerovanými volontéry byli studujicí české university v oboru archaeologie, pp. Jaroslav Böhm, Jaroslav Pasternak a Ivan Borkowskyj, vedle nichž občas pracovali v Ústavě bezplatně sl. Libuše Jansová a pan Jiři Müller (...) nebylo naprosto možno, aby Ústav bez těchto volontérů mohl úkol svůj a práce své rádně plniti. Podepsaný ředitel má proto za svou povinnost, znovu a dưrazně upozorniti, že bez povolení řádné síly asistentské nebude moci ručiti za dokonalé plnění úkolì Ústavnich, zejména když nyní celkový rozpočet Ústavu o značnou sumu byl snižen a tím dalši udržení honorovaných volontérů znemožněno" (NA, fond SPS, kart. 454; k pozici I. Borkovského mezi lety 1926-1938 viz MÚA, Státní archeologický ústav, fond 27, kart. 2, jednoznačně také J. Böhm k roku 1937). V archiváliích bývají však výše jmenovaní také označováni jako asistenti výzkumu.

\subsection{Role státní a municipální správy}

Významnou roli z hlediska všestranné podpory výzkumu, dokumentace a ochrany archeologických pramenů na území Prahy sehrálo MŠANO zejména v osobě Z. Wirtha, zodpovědného za oblast ochrany památek obecně (Uhlíková 2010). Pod jeho gescí byla tvorba nové celostátní koncepce včetně památkového zákona, z mnoha dokumentů vyplývá úzká kooperace s odbornými institucemi a s Památkovým sborem Magistrátu hl. města Prahy (MHMP). Evidentní je přitom skutečnost, že Praha a obecně pocit’ovaná nezbytnost ochrany četných a často výjimečných památek, skrytých po staletí pod její dlažbou či v dochovaných historických objektech, sloužila vzhledem ke komplexitě problematiky poznání a ochrany jejího kulturního dědictví při formulování celostátní koncepce jako hlavní inspirační zdroj.

Významnou roli sehrál v organizaci záchrany, dokumentace, ochrany i prezentace archeologických pramenů Magistrát hl. města Prahy, a to zřízením Památkového sboru jako poradního orgánu magistrátu pro oblast péče o historické památky na území Prahy. Ten byl ustanoven v roce 1921 a disponoval poměrně rozsáhlými kompetencemi v rovině teoretické i praktické (oficiální účast na tvorbě regulačních plánů města i magistrátních regulativů, možnost působení při prrípravě stavebních záměrů, účast na stavebních řízeních, systematická terénní dokumentace, preventivní působení, ochrana a prezentace památek, popularizace). V řadách jeho členů stanuli vedle pracovníků magistrátu, z nichž zásadní pro činnost sboru byla účast stavebního odboru, zástupci odborných institucí i veřejných spolků (blíže viz Boháčová 2019).

\subsection{Základní principy organizace historické archeologie v Praze}

Základní principy péče o archeologické prameny a vytvářenou koncepci archeologického studia Prahy lze odvodit z bohatého archivního fondu Památkového sboru v Archivu hl. města Prahy (AMP, MHMP, fond Památkový sbor), který zatím nebyl po této stránce systematicky vyhodnocen. Řadu cenných materiálů, mnohdy primárních dokumentů, konceptů pro jednání či pro oficiální písemnosti, zápisků aj., obsahuje osobní fond R. Hlubinky v Ústavu dějin umění AV ČR (ÚDU). Tyto prameny dokládají promyšlenou koncepci směřující $\mathrm{k}$ systematické dokumentaci a ochraně fondu archeologických pramenů Prahy. Ve stručnosti ji lze shrnout do několika hlavních bodů: 1) záchranný, potažmo předstihový výzkum v souvislosti se stavebními aktivitami, 2) výzkum vybraných prvořadých památek $\mathrm{v}$ návaznosti na zamýšlené rekonstrukční práce, úpravu veřejných prostranství či na vytváření koncepce rozvoje města, 3) aktivní působení ve prospěch ohrožených památek, at' již zcela nebo částečně archeologizovaných, v prŕípadě neodvratného zániku maximální snaha o jejich 
dokumentaci, 4) systematická evidence stavebních zásahů vycházející z úzké kooperace se stavebním odborem magistrátu a jejich sledování, 5) prezentace výsledků výzkumu veřejnosti, včetně snah o uchování a zpř́stupnění výjimečných archeologických nálezů in situ, 6) široká meziinstitucionální kooperace, 7) institut odborných komisí a konečně 8) snahy o interdisciplinární přístup (zvl. geologie, stavební historie aj.) a 9) systematická dokumentace dochovaných památek všech kategorií (v návaznosti na činnost někdejší soupisové komise) za současného budování profesionálního zázemí a zajištění návazné péče jak o hmotné prameny, tak o primární dokumentaci (kompetence odborně příslušných státních i městských institucí, pořizování vícečetných řad dokumentace; Boháčová 2019, 288-290).

\subsection{Realizace výzkumů - financování, personální zajištění, postexkavační péče o prameny a dokumentaci}

Intenzita a rozsah archeologických výzkumů byly samozřejmě závislé na kapacitách oboru, které byly značně omezené, a stejně tak na limitovaných finančních zdrojích. Financování výzkumů lze charakterizovat jako vícezdrojové - jeho základem byla každoroční podpora činnosti Památkového sboru magistrátem, pravidelně byly peníze poskytovány MŠANO a z Národního fondu Masarykova. Podkladem dotací byly každoroční žádosti Památkového sboru, který vždy za předchozí období předkládal vyúčtování provedených prací. Celkové sumy na výzkum se pohybovaly v řádech desetitisíců korun. Podle získaných prostředků pak bylo rozhodováno o provedení konkrétních výzkumů. Dílčí finanční prostředky byly získávány i podporou zaměstnávání tzv. nouzových dělníků prostřednictvím Ministerstva veřejných prací a také naprríklad z vybírání vstupného při akcích pro veřejnost.

Reálné provádění výzkumů bylo i přes promyšlenou koncepci a značné množství realizovaných terénních aktivit limitováno nedostatkem kvalifikovaných pracovníků na všech úrovních výzkumu. Situace byla řešena jednak omezením výzkumů na nejdůležitější lokality, jednak úzkou meziinstitucionální kooperací a využíváním všech dostupných „lidských zdrojü“ a finančních prostředků. Reálný podíl jednotlivých institucí na zabezpečení nezbytných terénních prací a dokumentaci odkryvů často nelze určit (tab. 1). Památkový sbor však mohl díky dotacím MŠANO a MHMP do roku 1939 zajištovat značnou část preventivních a záchranných výzkumů v historickém jádru města a někdy i mimo něj (Nový hrad v Kunraticích). Dotace umožnily i budování profesionálního dokumentačního zázemí (zejména fotodokumentace) a najímání stálých, a tedy již pro výzkum vyškolených externích odborníků na pořizování fotografické i měřičské dokumentace. Tyto odborníky posléze využívaly i státní instituce.

\section{Zapomenutí aktéři pražské archeologie a jejich role ve formování urbánní archeologie}

\subsection{Rudolf Hlubinka (1878-1954)}

O prosazování systematického studia archeologických pramenů Prahy a moderní koncepci jejich dokumentace, ochrany i prezentace se dlouhodobě zasazoval právník Rudolf Hlubinka (obr. 2), pracovník a vedoucí (1934-1938) stavebního odboru magistrátu a dlouhodobý referent Památkového sboru. Díky své angažovanosti, osobnímu nasazení a hlubokým znalostem v oblasti stavebních památek i archeologie se stal obecně uznávanou osobností (nap̌r. Z. Wirth označuje meziválečnou éru tvorby zásad dokumentace a ochrany památek jako ,éru Hlubinkovu“ - Wirth 1948).

Rudolf Hlubinka byl tvůrcem programu Památkového sboru i výše definované koncepce praktické památkové péče $\mathrm{v}$ Praze, za jejíž podstatnou součást považoval péči o archeologické prameny. Soustavně a do značné míry úspěšně se zasazoval o její uvádění do praxe. Zastával pozici magistrátního rady, byl členem Klubu za Starou Prahu (člen domácí rady a redaktorem Věstníku Klubu za Starou Prahu), Společnosti přátel starožitností i Společnosti českých prehistoriků.

Ačkoliv byl vzděláním právník, díky svým aktivitám na poli archeologie (nejen pražské) byl označován i za archeologa. Podílel se na dokumentaci památek odkrytých při stavebních 


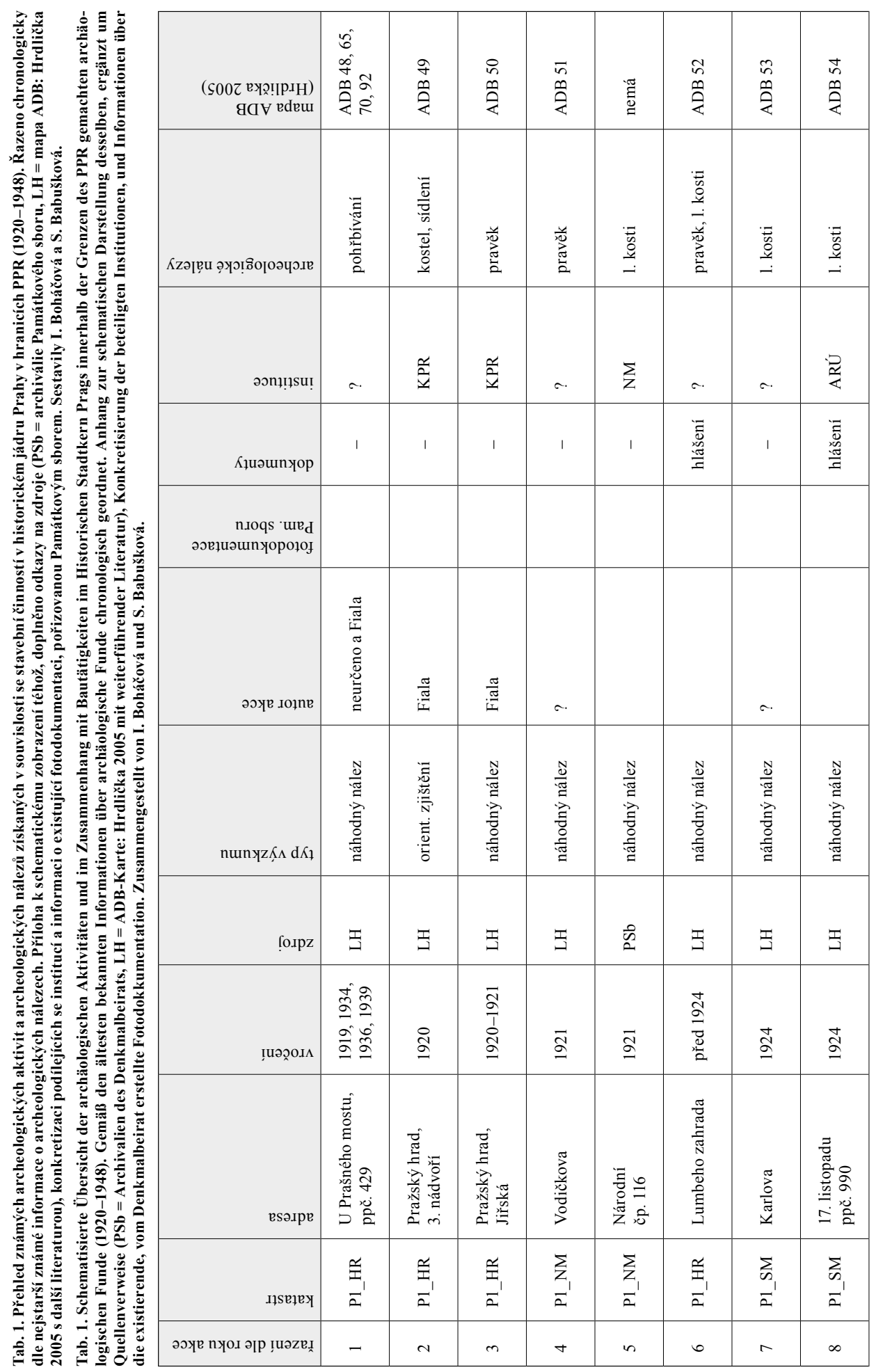




\begin{tabular}{|c|c|c|c|c|c|c|c|c|c|c|c|}
\hline $\begin{array}{l}\stackrel{ \pm}{\sim} \\
\text { 蓆 }\end{array}$ & 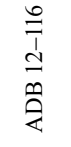 & 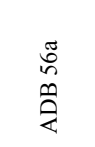 & 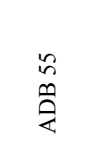 & 莺 & $\begin{array}{l}\vec{\infty} \\
\text { 苨 }\end{array}$ & 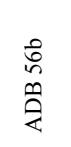 & $\begin{array}{l}\hat{\theta} \\
\hat{\psi}\end{array}$ & 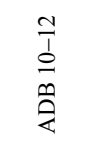 & 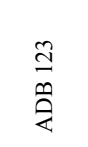 & 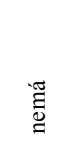 & 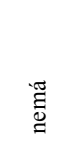 \\
\hline 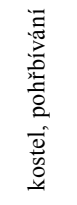 & 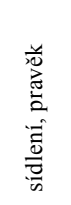 & 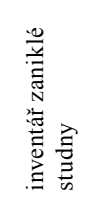 & 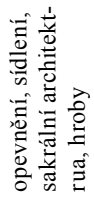 & 害 & $\begin{array}{l}\overrightarrow{0} \\
\stackrel{0}{\Xi}\end{array}$ & 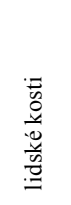 & 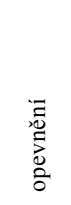 & 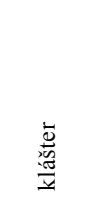 & 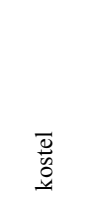 & 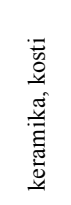 & 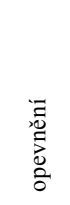 \\
\hline 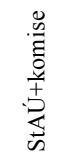 & 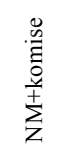 & $\frac{\stackrel{n}{\vec{y}}}{1}$ & 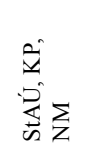 & ह & $\begin{array}{l}0 \\
\hat{n} \\
\sum \\
\sum\end{array}$ & 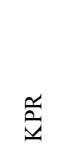 & $\vec{\omega}$ & 蛋 & क्ष & a. & a. \\
\hline $\begin{array}{l}\text { 节 } \\
\text { 吾 }\end{array}$ & 弟 & 1 & $\begin{array}{l}\ddot{z} \\
\ddot{y}\end{array}$ & 号营 & 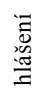 & 1 & 1 & $\begin{array}{l}\text { 离 } \\
\text { 兽 } \\
\text { I }\end{array}$ & 1 & 1 & 1 \\
\hline+ & + & & $\begin{array}{l}\stackrel{q}{\sigma} \\
\stackrel{+}{+}\end{array}$ & + & + & & + & + & 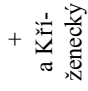 & + & + \\
\hline 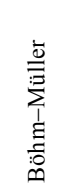 & 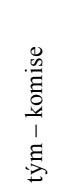 & $\frac{\pi}{\frac{\pi}{\pi}}$ & 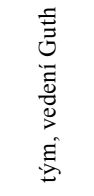 & 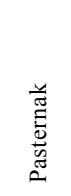 & 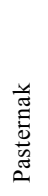 & 吾 & 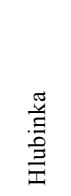 & $\begin{array}{l}\text { : } \\
: 0 \\
\infty\end{array}$ & 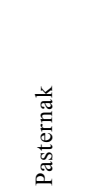 & & \\
\hline 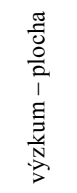 & $\begin{array}{l}\frac{\pi}{0} \\
\frac{0}{0} \\
\frac{0}{2} \\
1 \\
\frac{1}{3} \\
\frac{1}{N} \\
\frac{3}{3}\end{array}$ & 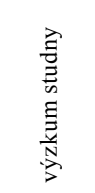 & $\begin{array}{l}\frac{\pi}{0} \\
\frac{0}{2} \\
1 \\
1 \\
\frac{1}{N} \\
\frac{0}{3}\end{array}$ & 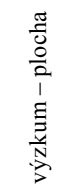 & 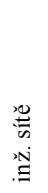 & 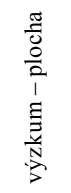 & $\begin{array}{l}\frac{\pi}{0} \\
0 \\
0 \\
0 \\
1 \\
0 \\
\frac{0}{\pi} \\
0 \\
0\end{array}$ & $\begin{array}{l}\frac{\pi}{0} \\
\frac{0}{2} \\
1 \\
1 \\
\frac{1}{N} \\
\frac{0}{5} \\
\frac{1}{3}\end{array}$ & $\begin{array}{l}\frac{\pi}{0} \\
\frac{0}{2} \\
\frac{1}{2} \\
1 \\
\vdots \\
\frac{0}{N} \\
3\end{array}$ & 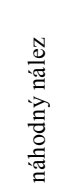 & 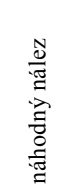 \\
\hline 当 & 寻 & 声 & 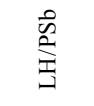 & w & 寻 & J & 声 & 点 & 量 & के & $\ddot{n}$ \\
\hline 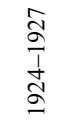 & 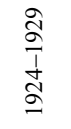 & $\stackrel{2}{\varrho}$ & 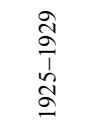 & $\underset{\Omega}{2}$ & $\stackrel{\text { న̆ }}{2}$ & 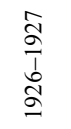 & 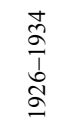 & 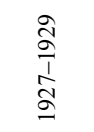 & $\widehat{\widehat{\Omega}}$ & $\stackrel{\text { }}{\sigma}$ & $\stackrel{\infty}{\Omega}$ \\
\hline 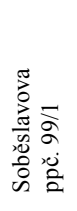 & 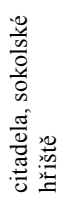 & 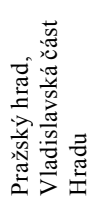 & 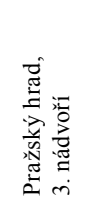 & 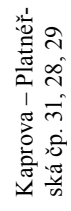 & 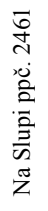 & 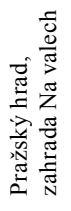 & 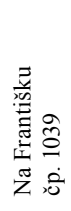 & 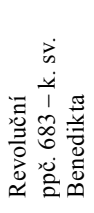 & 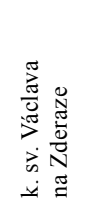 & 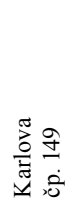 & 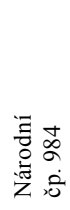 \\
\hline $\begin{array}{l}J^{\prime} \\
\Sigma^{\prime}\end{array}$ & $\begin{array}{l}\nearrow_{3} \\
\mathfrak{z}^{\prime}\end{array}$ & 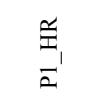 & $\begin{array}{l}\underline{a} \\
\vec{a}\end{array}$ & $\begin{array}{l}\sum_{n} \\
\vec{a}_{1}\end{array}$ & $\begin{array}{l}\sum_{Z_{1}} \\
\mathfrak{Z}^{\prime}\end{array}$ & $\begin{array}{l}\sum_{1}^{n} \\
a_{1}\end{array}$ & $\begin{array}{l}\sum_{n} \\
\vec{a}_{1}\end{array}$ & $\begin{array}{l}\sum_{\infty} \\
-1\end{array}$ & $\begin{array}{l}\sum_{Z_{1}} \\
\Sigma^{\prime}\end{array}$ & $\begin{array}{l}\sum_{\infty} \\
\Sigma_{1}\end{array}$ & $\begin{array}{l}\sum_{n} \\
I_{1}\end{array}$ \\
\hline$a$ & 은 & $=$ & $\simeq$ & 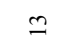 & \pm & $\cong$ & 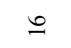 & $=$ & $\stackrel{\infty}{\simeq}$ & 9 & ๙ \\
\hline
\end{tabular}




\begin{tabular}{|c|c|c|c|c|c|c|c|c|c|c|}
\hline 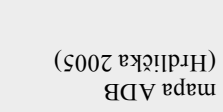 & 䓤 & 苑 & 营 & 范 & $\begin{array}{l}\text { nे } \\
\text { ڤै } \\
\text { \& }\end{array}$ & 莺 & $\begin{array}{l}8 \\
\text { 贯 }\end{array}$ & $\begin{array}{l}\vec{\sigma} \\
\text { 娄 }\end{array}$ & $\begin{array}{l}\stackrel{n}{=} \\
\stackrel{m}{Q}\end{array}$ & $\begin{array}{l}\infty \\
\infty \\
\tilde{m} \\
\text { \& }\end{array}$ \\
\hline 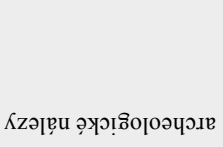 & 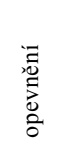 & 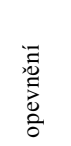 & 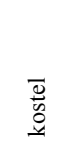 & 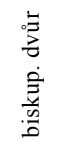 & 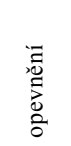 & 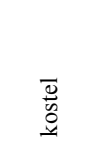 & 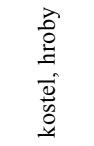 & 禀 & 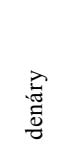 & 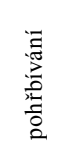 \\
\hline әэṇฺ!ฺsu! & $\begin{array}{l}0 \\
\kappa\end{array}$ & के & 号 & $\hat{n}$ & $\stackrel{\underline{a}}{\underline{a}}$ & $\begin{array}{l}0 \\
\approx\end{array}$ & 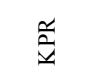 & $\frac{\approx}{\vec{a}}$ & a. & $\sum_{\sum}^{e}$ \\
\hline Кұчәәшичор & 1 & 1 & 1 & 1 & 1 & 1 & 1 & 1 & 1 & 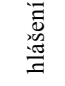 \\
\hline 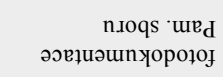 & + & + & + & + & & + & & & & \\
\hline әэу .оฺnย & 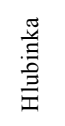 & 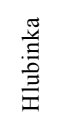 & 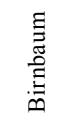 & & 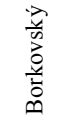 & 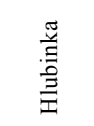 & 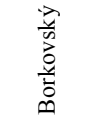 & 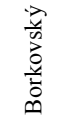 & & \\
\hline nuny $\mathrm{Z}_{\Lambda} \Lambda \mathrm{d} \kappa_{\mathfrak{l}}$ & $\begin{array}{l}\frac{g}{0} \\
\frac{0}{2} \\
\frac{1}{0} \\
\frac{0}{\pi} \\
\frac{0}{0} \\
\frac{0}{0}\end{array}$ & $\begin{array}{l}\frac{\pi}{0} \\
\frac{0}{0} \\
1 \\
\frac{0}{0} \\
\frac{0}{0} \\
\frac{0}{0}\end{array}$ & 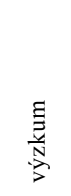 & 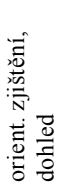 & 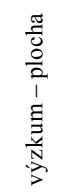 & 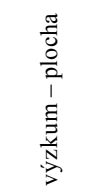 & 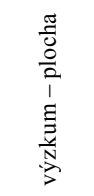 & 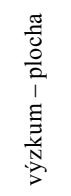 & 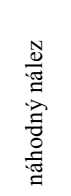 & 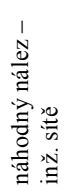 \\
\hline Co.spz & के & क & $\begin{array}{l}0 \\
\approx\end{array}$ & $\hat{n}^{2}$ & 声 & $\begin{array}{l}0 \\
2\end{array}$ & 岑 & 当 & 当 & 当 \\
\hline 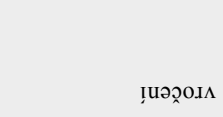 & $\stackrel{\infty}{\mathscr{L}}$ & $\stackrel{\infty}{\mathscr{\Omega}}$ & 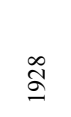 & 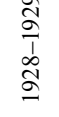 & ఏે & ूे & ळু & 今े & $\stackrel{0}{2}$ & 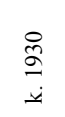 \\
\hline esəupe & 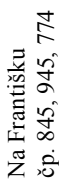 & 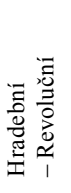 & 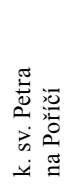 & 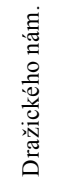 & 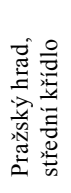 & 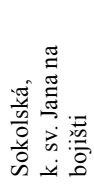 & 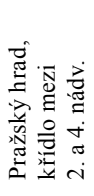 & 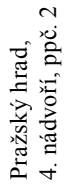 & 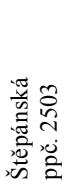 & 总 \\
\hline IIISBIeY & $\begin{array}{l}\sum_{n} \\
a_{1}\end{array}$ & $\begin{array}{l}\sum_{n} \\
\Sigma_{1}^{\prime}\end{array}$ & $\begin{array}{l}\sum_{Z_{1}} \\
\Sigma^{\prime}\end{array}$ & $\frac{\sum_{1}^{\infty}}{a_{1}}$ & $\begin{array}{l}\cong \\
\underline{\Xi^{\prime}} \\
\overrightarrow{a^{\prime}}\end{array}$ & $\begin{array}{l}\sum_{1} \\
\Sigma_{1}\end{array}$ & $\begin{array}{l}\underline{\Xi} \\
\overrightarrow{a_{1}}\end{array}$ & $\begin{array}{l}\cong \\
\overrightarrow{a_{1}}\end{array}$ & $\begin{array}{l}\sum_{1} \\
\Sigma_{1}\end{array}$ & $\begin{array}{l}\sum_{1}^{n} \\
a_{1}\end{array}$ \\
\hline әэүе пуо. әрр !̣шәzе. & $\bar{\sim}$ & สิ & $\tilde{\imath}$ & $\stackrel{\Delta}{4}$ & 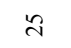 & i & $\hat{\imath}$ & $\stackrel{i}{i}$ & ते & in \\
\hline
\end{tabular}




\begin{tabular}{|c|c|c|c|c|c|c|c|c|c|c|c|}
\hline 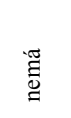 & $\begin{array}{l}\text { S } \\
\text { 蓆 }\end{array}$ & 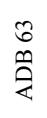 & $\begin{array}{l}\triangleright \\
\infty \\
\stackrel{⿳}{0} \\
\&\end{array}$ & 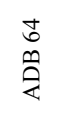 & 营 & 莺 & 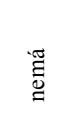 & 莺 & $\stackrel{\text { }}{\stackrel{\sim}{\Xi}}$ & $\begin{array}{l}\Xi \\
\stackrel{0}{\ominus}\end{array}$ & 莺 \\
\hline 罵 & 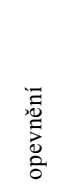 & 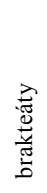 & a. & 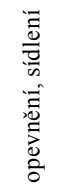 & 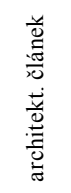 & 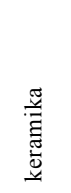 & 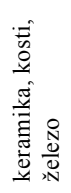 & 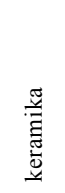 & 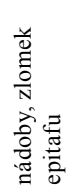 & 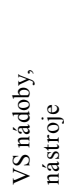 & 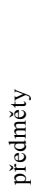 \\
\hline$\stackrel{\infty}{\infty}$ & $\stackrel{\widetilde{a}}{\tilde{\Delta}}$ & $a$ & $\stackrel{\widetilde{a}}{\vec{\Delta}}$ & $\stackrel{a}{\vec{a}}$ & a. & a. & a. & a. & a. & a. & a. \\
\hline 1 & 1 & 1 & 1 & 1 & & & & & & 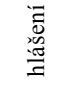 & \\
\hline+ & & & & & + & + & + & + & + & + & + \\
\hline 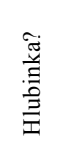 & 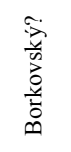 & & 豞 & 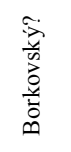 & & & & & & & \\
\hline 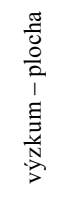 & 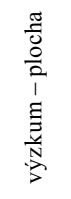 & 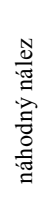 & $\begin{array}{l}\frac{\tilde{y}}{0} \\
\frac{d}{7} \\
\frac{0}{0}\end{array}$ & 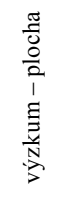 & 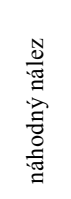 & 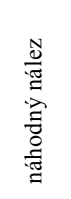 & 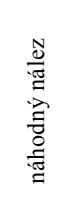 & 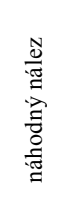 & 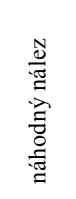 & 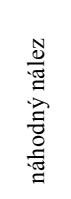 & 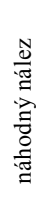 \\
\hline$\vec{w}$ & 声 & 当 & 当 & 声 & $\begin{array}{l}\vec{n} \\
\approx\end{array}$ & ह & ह & है & ह & $\begin{array}{l}\text { के } \\
\hat{0} \\
\text { J }\end{array}$ & है \\
\hline $\bar{\Omega}$ & $\frac{\tilde{\sigma}}{\stackrel{\Xi}{\sigma}}$ & $\tilde{\Omega}$ & & $\ddot{\tilde{\sigma}}$ & $\stackrel{\varkappa}{2}$ & $\stackrel{\aleph}{\sigma}$ & 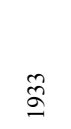 & ๙ૂ & ભૂ & $\begin{array}{l}\stackrel{J}{\Omega} \\
\tilde{\sigma}\end{array}$ & 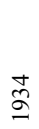 \\
\hline 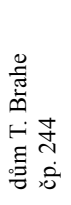 & 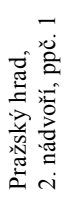 & 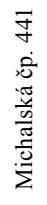 & 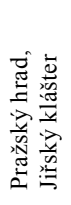 & 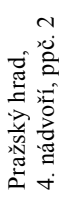 & 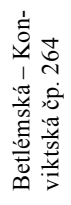 & 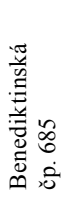 & 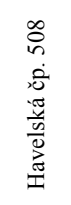 & 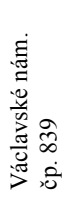 & 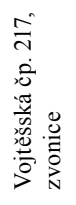 & 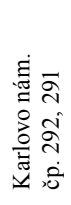 & 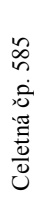 \\
\hline $\begin{array}{l}\stackrel{\Xi}{\Xi_{1}} \\
\vec{a}\end{array}$ & $\begin{array}{l}\underline{\Xi} \\
\vec{a}\end{array}$ & $\begin{array}{l}\sum_{\infty} \\
\bar{n}\end{array}$ & $\begin{array}{l}\cong \\
\stackrel{\Xi}{I_{1}}\end{array}$ & $\begin{array}{l}\cong \\
\vec{a} \\
\vec{a}\end{array}$ & $\begin{array}{l}\sum_{1} \\
a_{1}\end{array}$ & $\begin{array}{l}\sum_{\infty} \\
\vec{a}^{\prime}\end{array}$ & $\begin{array}{l}\sum_{n} \\
\vec{a}_{1}\end{array}$ & $\begin{array}{l}\sum_{\infty} \\
\vec{n}_{1}\end{array}$ & $\begin{array}{l}\sum_{\infty} \\
\mathbb{a}^{\prime}\end{array}$ & $\begin{array}{l}\sum_{1} \\
\Sigma_{1} \\
\Sigma^{\prime}\end{array}$ & $\begin{array}{l}\sum \\
\vec{n}_{1} \\
\Sigma\end{array}$ \\
\hline$\vec{m}$ & ल & $m$ & 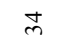 & $\approx$ & ల & $\hat{m}$ & $\stackrel{\infty}{m}$ & mे & o & $F$ & F \\
\hline
\end{tabular}




\begin{tabular}{|c|c|c|c|c|c|c|c|c|c|c|}
\hline 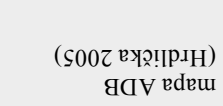 & 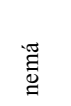 & $\begin{array}{l}\stackrel{8}{0} \\
\stackrel{m}{0}\end{array}$ & $\begin{array}{l}\hat{b} \\
\text { 芒 } \\
\text { \& }\end{array}$ & $\begin{array}{l}\overrightarrow{\hat{n}} \\
\stackrel{\tilde{A}}{\&}\end{array}$ & 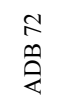 & 莺 & $\begin{array}{l}\text { ò } \\
\text { 官 }\end{array}$ & 苞 & 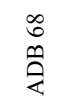 & $\begin{array}{l}\stackrel{n}{0} \\
\stackrel{m}{0}\end{array}$ \\
\hline 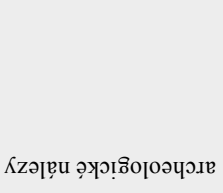 & 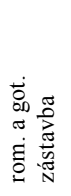 & 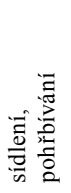 & 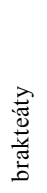 & 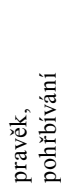 & 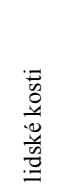 & 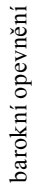 & $\begin{array}{l}\overrightarrow{0} \\
\stackrel{0}{\Xi}\end{array}$ & 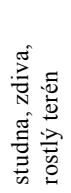 & 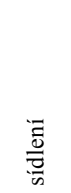 & 웅 \\
\hline әоnฺְ!ุsu! & की & है & a. & 它 & 胥 & के & a. & a. & ह & $\hat{n}$ \\
\hline Кұчәшшияор & & 1 & 1 & 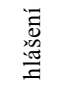 & 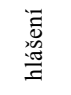 & 1 & 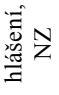 & & 1 & 1 \\
\hline 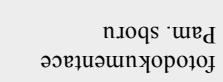 & + & $\begin{array}{c}\tilde{\sigma} \\
\tilde{r} \\
+\end{array}$ & & & & + & & + & + & + \\
\hline әэу⿰ .оฺnย & 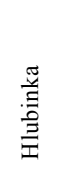 & 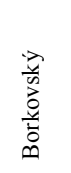 & a. & 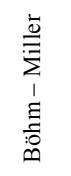 & 总 & & 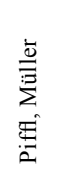 & & 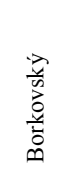 & 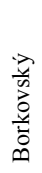 \\
\hline 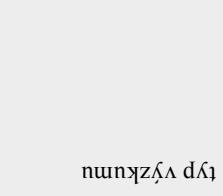 & 壳 & 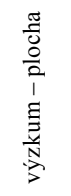 & 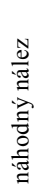 & $\begin{array}{l}\text { Z } \\
N \\
\text { ḋ } \\
\frac{0}{\pi} \\
\frac{0}{0}\end{array}$ & 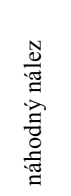 & 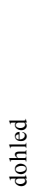 & 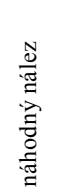 & 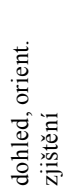 & 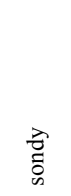 & 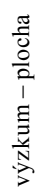 \\
\hline !o.spz & के & 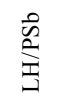 & $\Xi$ & 声 & 当 & $\begin{array}{l}\infty \\
\stackrel{n}{2}\end{array}$ & 当 & $\begin{array}{l}2 \\
\cdots\end{array}$ & 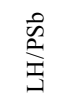 & 点 \\
\hline 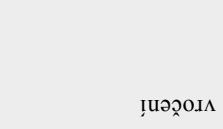 & 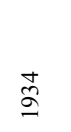 & 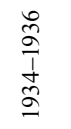 & $\stackrel{n}{\sigma}$ & $\stackrel{\circ}{\varrho}$ & $\stackrel{2}{\varrho}$ & $\stackrel{0}{\varrho}$ & $\stackrel{\overbrace{}}{\cong}$ & ֻু & ஜூ & 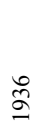 \\
\hline вsә.jpe & 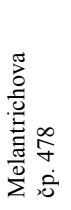 & 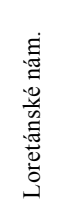 & 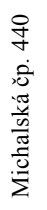 & $\begin{array}{l}\dot{\Xi} \\
\stackrel{\Xi}{\Xi} \\
\stackrel{\overrightarrow{0}}{\varrho}\end{array}$ & 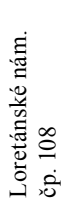 & 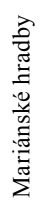 & 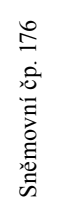 & 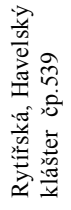 & 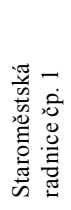 & 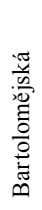 \\
\hline дыsереу & $\begin{array}{l}\sum_{n} \\
\vec{n}^{\prime}\end{array}$ & $\begin{array}{l}\stackrel{a}{\Xi_{1}} \\
\vec{a}_{1}\end{array}$ & $\begin{array}{l}\sum_{1} \\
\bar{n}_{1}\end{array}$ & $\begin{array}{l}\stackrel{a}{\Xi_{1}} \\
\vec{a}\end{array}$ & $\begin{array}{l}\stackrel{a}{\mathbf{I}_{1}} \\
\overrightarrow{a_{1}}\end{array}$ & 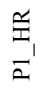 & $\sum_{a_{1}}^{\infty}$ & $\begin{array}{l}\sum_{\infty} \\
\bar{a}_{1}\end{array}$ & $\begin{array}{l}\sum_{n} \\
\vec{a}_{1}\end{array}$ & $\begin{array}{l}\sum_{1} \\
\sum_{1}\end{array}$ \\
\hline 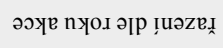 & $q$ & 字 & '尔 & fo & f & $\stackrel{\infty}{+}$ & gे & in & $\vec{n}$ & กี \\
\hline
\end{tabular}




\begin{tabular}{|c|c|c|c|c|c|c|c|c|c|c|c|}
\hline 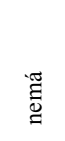 & 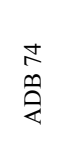 & $\begin{array}{l}\stackrel{2}{2} \\
\stackrel{\tilde{O}}{\&}\end{array}$ & 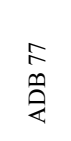 & $\begin{array}{l}\tilde{n} \\
\tilde{n} \\
\ddot{\varepsilon}\end{array}$ & 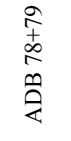 & 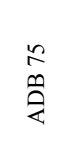 & 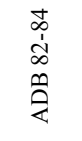 & $\begin{array}{l}\bar{\sigma} \\
\dot{1} \\
\infty \\
m \\
\stackrel{0}{\ominus}\end{array}$ & 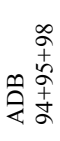 & $\begin{array}{l}\stackrel{2}{2} \\
\text { 艺 }\end{array}$ & $\begin{array}{l}\hat{\hat{\alpha}} \\
\hat{\tilde{u}}\end{array}$ \\
\hline 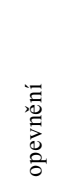 & 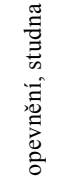 & 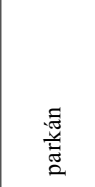 & 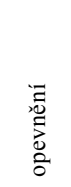 & 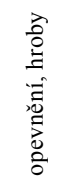 & 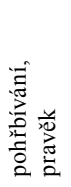 & 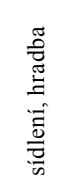 & 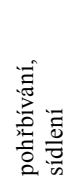 & 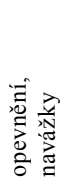 & 离总 & 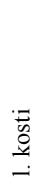 & 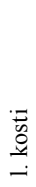 \\
\hline ह & 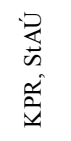 & 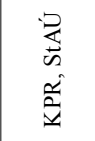 & 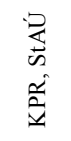 & a. & ह & $\overrightarrow{\tilde{\Xi}}$ & ह & 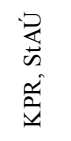 & 胥 & $a$. & a. \\
\hline 1 & 1 & 1 & 1 & 1 & $\mathrm{z}$ & 1 & 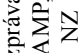 & 1 & 1 & 1 & 1 \\
\hline+ & & & & & & & + & & & & \\
\hline & 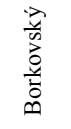 & 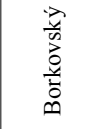 & 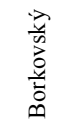 & 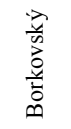 & 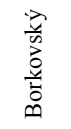 & 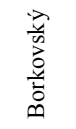 & 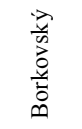 & 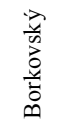 & 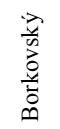 & & \\
\hline$\frac{\vec{d}}{\vec{J}}$ & 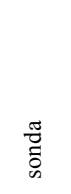 & 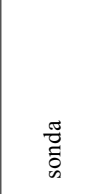 & 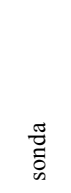 & 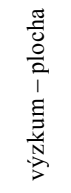 & 玄 & 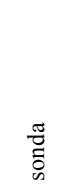 & $\begin{array}{l}\frac{\pi}{0} \\
\frac{0}{2} \\
1 \\
1 \\
\frac{1}{N} \\
\frac{0}{5}\end{array}$ & $\begin{array}{l}\text { 莺 } \\
\text { : }\end{array}$ & $\begin{array}{l}\frac{\pi}{0} \\
\frac{0}{2} \\
1 \\
1 \\
\frac{1}{3} \\
\frac{0}{3}\end{array}$ & 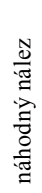 & 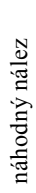 \\
\hline के & 声 & 可 & 岑 & 寻 & 声 & 岁 & 可 & 寻 & 当 & 寻 & 当 \\
\hline 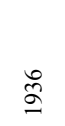 & 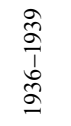 & 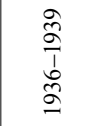 & 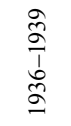 & $\tilde{\Omega}$ & $\hat{\sigma}$ & $\frac{\infty}{\frac{\infty}{n}}$ & $\stackrel{\infty}{\approx}$ & $\begin{array}{l}\hat{\sigma} \\
\frac{\hat{\sigma}}{\infty} \\
\tilde{\sigma}\end{array}$ & $\begin{array}{l}\text { İ } \\
\text { İ } \\
\bar{d} \\
\text { वे }\end{array}$ & $\begin{array}{l}\vec{F} \\
\stackrel{\vec{O}}{\vec{D}} \\
\text { 总 }\end{array}$ & 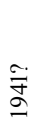 \\
\hline 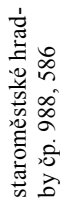 & 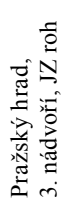 & 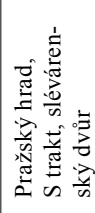 & 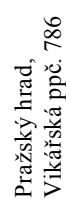 & 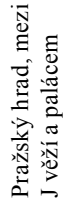 & $\begin{array}{l}\dot{\Xi} \\
\stackrel{\Xi}{\bar{\Xi}} \\
\stackrel{0}{0}\end{array}$ & 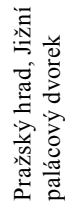 & 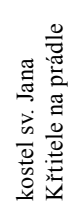 & 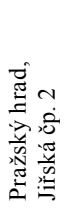 & 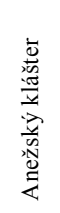 & 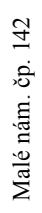 & 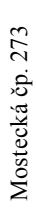 \\
\hline $\begin{array}{l}\sum_{n} \\
a_{1}\end{array}$ & $\begin{array}{l}\stackrel{a}{\mathbf{I}_{1}} \\
\overrightarrow{a^{\prime}}\end{array}$ & $\begin{array}{l}\stackrel{a}{\Xi_{1}} \\
\overrightarrow{a^{\prime}}\end{array}$ & $\begin{array}{l}\underline{a_{1}} \\
\vec{a}\end{array}$ & $\begin{array}{l}\cong \\
\underline{\Xi_{1}} \\
\underline{a^{\prime}}\end{array}$ & $\begin{array}{l}\stackrel{\approx}{\Xi_{1}} \\
\vec{a}\end{array}$ & $\begin{array}{l}\underline{\mathbf{I}_{1}} \\
\overrightarrow{a_{1}}\end{array}$ & $\frac{\sum_{1}^{\infty}}{\Sigma_{1}}$ & $\begin{array}{l}\stackrel{a}{I_{1}} \\
\underline{a}\end{array}$ & $\begin{array}{l}\sum_{n} \\
I_{1}\end{array}$ & $\begin{array}{l}\sum_{n} \\
\Sigma_{1}\end{array}$ & $\begin{array}{l}\sum_{1}^{n} \\
\Sigma_{1}\end{array}$ \\
\hline$n$ & in & $n$ & $i$ & in & $\stackrel{\infty}{n}$ & in & 8 & $\bar{\sigma}$ & ธิ & 8 & t \\
\hline
\end{tabular}




\begin{tabular}{|c|c|c|c|c|c|c|c|c|c|c|}
\hline 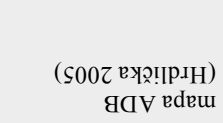 & $\begin{array}{l}\frac{1}{m} \\
m \\
\frac{m}{2}\end{array}$ & $\begin{array}{l}\text { बे } \\
\text { 究 }\end{array}$ & $\begin{array}{l}\stackrel{8}{\circ} \\
\stackrel{m}{Q}\end{array}$ & $\begin{array}{l}\frac{\bar{\Xi}}{m} \\
\text { 究 }\end{array}$ & 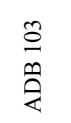 & 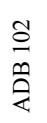 & 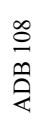 & 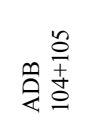 & $\begin{array}{l}\stackrel{\infty}{=} \\
\stackrel{\infty}{\ominus}\end{array}$ & $\begin{array}{l}\stackrel{\partial}{o} \\
\text { 产 }\end{array}$ \\
\hline 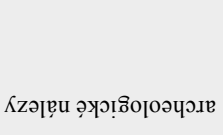 & $\begin{array}{l}\bar{v} \\
\bar{w} \\
\stackrel{w}{u}\end{array}$ & $\frac{\bar{\Xi}}{\overline{0}}$ & 咅 & $\frac{\overline{0}}{\overline{0}}$ & 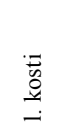 & 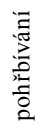 & 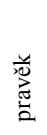 & 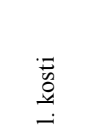 & 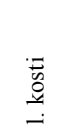 & 胥 \\
\hline әоnฺְ!ุsu! & a. & 导 & 导 & 导 & 导 & 导 & a. & 导 & 导 & 焉 \\
\hline Кұшәшичүор & 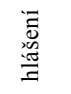 & 1 & 1 & 1 & 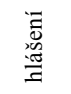 & $\mathrm{z}$ & 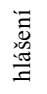 & 1 & 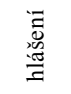 & 1 \\
\hline 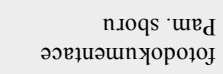 & & & & & & & & & & \\
\hline әэу⿰ .оฺnย & 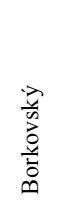 & 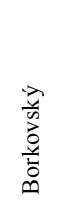 & 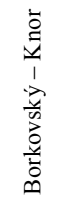 & 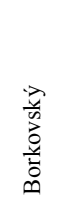 & 节 & 总 & & 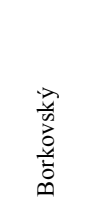 & 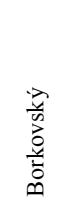 & 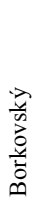 \\
\hline nuny $y K_{\Lambda} \Lambda \mathrm{d} \kappa_{7}$ & 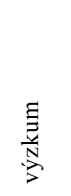 & 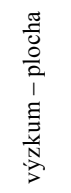 & 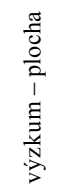 & 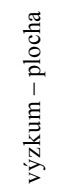 & 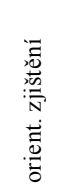 & 离 & 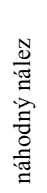 & 莺 & 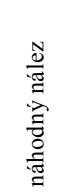 & $\frac{\bar{d}}{\frac{d}{d}}$ \\
\hline !o.spz & 当 & 可 & 声 & 声 & 可 & 当 & 声 & 寻 & 声 & 声 \\
\hline 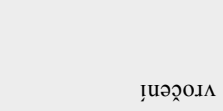 & I & f & f & 索 & 桀 & ga & 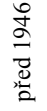 & $\stackrel{0}{2}$ & $\stackrel{0}{9}$ & ક \\
\hline esəape & 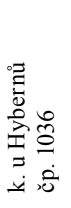 & 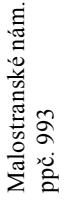 & 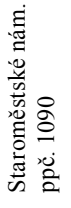 & 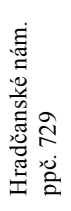 & 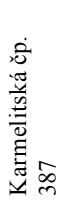 & 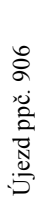 & 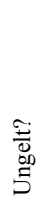 & 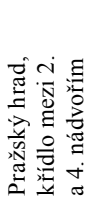 & 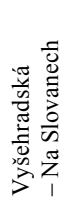 & 莺 \\
\hline дұsęey & $\begin{array}{l}\sum_{1} \\
\vec{n}_{1}\end{array}$ & $\begin{array}{l}\sum_{1}^{\infty} \\
\Sigma_{1}\end{array}$ & $\begin{array}{l}\sum_{1} \\
\vec{n}_{1}\end{array}$ & $\begin{array}{l}\underline{a} \\
\vec{I}_{1} \\
\vec{a}_{1}\end{array}$ & $\frac{\sum_{1}^{n}}{a_{1}}$ & $\begin{array}{l}\sum_{1}^{n} \\
a_{1}\end{array}$ & $\begin{array}{l}\sum_{n} \\
a_{1}\end{array}$ & $\begin{array}{l}\underline{\Xi_{1}} \\
\vec{a}\end{array}$ & $\begin{array}{l}\sum_{Z_{1}} \\
\Sigma_{1}\end{array}$ & $\begin{array}{l}\underline{a} \\
\vec{a}\end{array}$ \\
\hline 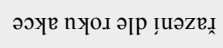 & 3 & 8 & 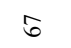 & $\infty$ & 8 & $\therefore$ & 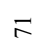 & 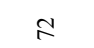 & $\approx$ & $g$ \\
\hline
\end{tabular}




\begin{tabular}{|c|c|c|c|c|}
\hline 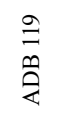 & $\begin{array}{l}2 \\
\hat{\imath} \\
\hat{\varepsilon}\end{array}$ & $\begin{array}{l}\stackrel{一}{=} \\
\stackrel{m}{\ominus}\end{array}$ & 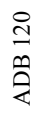 & 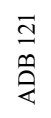 \\
\hline 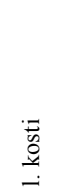 & 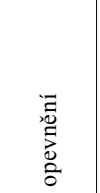 & 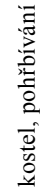 & 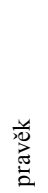 & 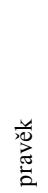 \\
\hline 导 & 导 & 空 & a. & a. \\
\hline 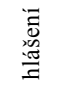 & 1 & 1 & 离 & 1 \\
\hline 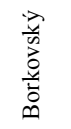 & 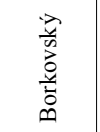 & 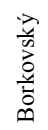 & & \\
\hline 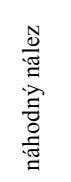 & 莺 & $\begin{array}{l}\frac{\pi}{0} \\
\frac{0}{2} \\
\frac{1}{1} \\
\frac{1}{3} \\
\frac{\pi}{N} \\
\frac{3}{3}\end{array}$ & 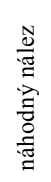 & 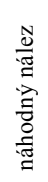 \\
\hline 寻 & 当 & 岑 & 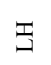 & 寻 \\
\hline 亲 & 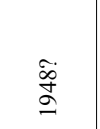 & $\begin{array}{l}\stackrel{d}{d} \\
\stackrel{1}{a} \\
\stackrel{0}{a}\end{array}$ & 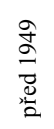 & 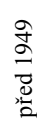 \\
\hline 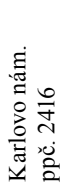 & 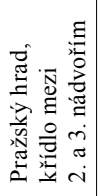 & 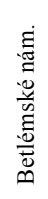 & $\begin{array}{l}\tilde{N} \\
\mathbb{\tilde { J }} \\
N \\
\tilde{Z} \\
\widetilde{Z}\end{array}$ & 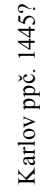 \\
\hline $\begin{array}{l}\sum_{Z_{1}} \\
\Sigma^{\prime}\end{array}$ & $\begin{array}{l}\underline{y_{1}} \\
\overrightarrow{a^{\prime}}\end{array}$ & $\sum_{i}$ & $\begin{array}{l}\sum_{Z_{1}} \\
\Omega^{\prime}\end{array}$ & $\begin{array}{l}\sum_{Z_{1}} \\
\Sigma^{\prime}\end{array}$ \\
\hline 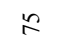 & 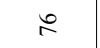 & $\approx$ & $\stackrel{\infty}{\gtrless}$ & 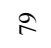 \\
\hline
\end{tabular}

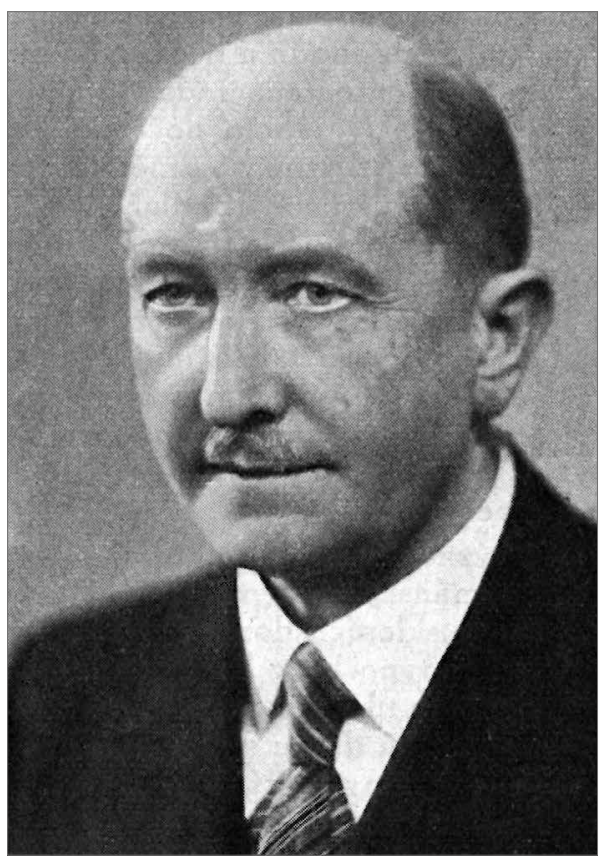

Obr. 2. Rudolf Hlubinka v roce 1938. Převzato a upraveno z věstníku Za starou Prahu, 1938, 45, signováno J. A. [Jan Almer].

Abb. 2. Rudolf Hlubinka im Jahr 1938. Entnommen und bearbeitet aus dem Anzeiger Für das alte Prag, 1938, 45, signiert J. A. [Jan Almer].

pracích, dochovány jsou např́íklad jeho záznamy o stratigrafii (mezi jinými detailní popis výkopu na Hradčanském náměstí v roce 1944 ÚDU, H 7/3). Soustavně sledoval magistrátem evidované stavební zásahy, pořizoval průběžně dokumentaci slovní i měřičskou, zaměření celé řady památek zajištoval a organizoval at' již prostřednictvím najímaných profesionálů nebo díky spolupráci s pražským technickým učením a s jeho studenty či absolventy, od roku 1928 také s V. Menclem (AMP, MHMP fond Památkový sbor, kart. 17, inv. č. 30). Archiválie opakovaně dokládají také jeho snahy o zajištění předstihových výzkumů ohrožených památek (Loretánské nám., Platnéřská - Kaprova, kostel sv. Václava na Zderaze, kostel sv. Jana Křtitele na prádle, kostel sv. Jana na bojišti, Bartolomějská ul., Staroměstská radnice, Nový hrad v Kunraticích, dům Tychona Brahe). Přehled všech realizovaných výzkumů či náhodných archeologických nálezů, které proběhly v gesci Památkového sboru (obr. 1; tab. 1), byl 
zpracován na základě výpovědi dřive nezpracovaných archiválií a nemusí být ještě definitivní. Některé ze záměrů formulovaných Hlubinkou (opakované podněty k přislíbeným výzkumům před zadlážděním ploch - kaple Božího Těla, kostel P. Marie na louži, kostel sv. Filipa a Jakuba na Smíchově; obr. 3) zůstaly nakonec nerealizovány. Archiválie (zvláště AMP, MŠANO, fond Památkový sbor; ÚDU, H 2/2,7/8) dokládají, že systematické sledování stavebních aktivit bylo ošetřeno administrativně. V souvislosti s výkopy v historickém jádru byl oslovován i Státní geologický ústav (obr. 4). R. Hlubinka také osobně dohlížel na stavební aktivity v místech potenciálních objevů. Průběžně se zasazoval o ochranu památek i historicky (archeologicky i stavebně historicky) cenných ploch, jejichž vymezení v historickém jádru Prahy se rovněž nachází mezi archiváliemi v jeho

Výpis ze záăpisu o schüi Pam.sboru dne 11./V.1928. /̌.j.1ei/2o.F.sb./.

Referent nodal zorávu o odpovědi hosp.ref.I.C. ve věci výkopi zbytki kosteli $\mathrm{v}$ pražskf́ch ulicích pred vyasfaltováním. Zádné z uveden'ch míst nebude v r.19r8 asfaltováno. Sedání vykonané puảy prý trvá dva roky. Feferent vyslovil obavu že těžké bude jedhání o uhradu velkého nákladu a o výkopy vỉbec. Upozornil, že na Marianskén nám. má se zrríditi refuge pro usměrnění vozby a to by byla vhodná prrilëžitost $k$ urychlenému v'kopu kostela $p$. Marie na Louži tedy dříve, než bude dokončen primatoriv representeční byt v novostavbě ustred.měst.knihovny. Pan Ir Guth dále žádá,aby stejnĕ urychieně byla żišctěna kostelní věž Betlemské kaple rả Betienském nám., která jistě bude asfaltováno. Pan kanovník Šittler žádá, aby pamatováno bylo na výkop zbytki kostela F.llarie, pak alžběty před vyšehrad. býv.radnicí. heferent zmocnĕn $k$ př́siuš.projeananí možnosti rychlého výkopu na warianskèm a Betlemském náměstí.

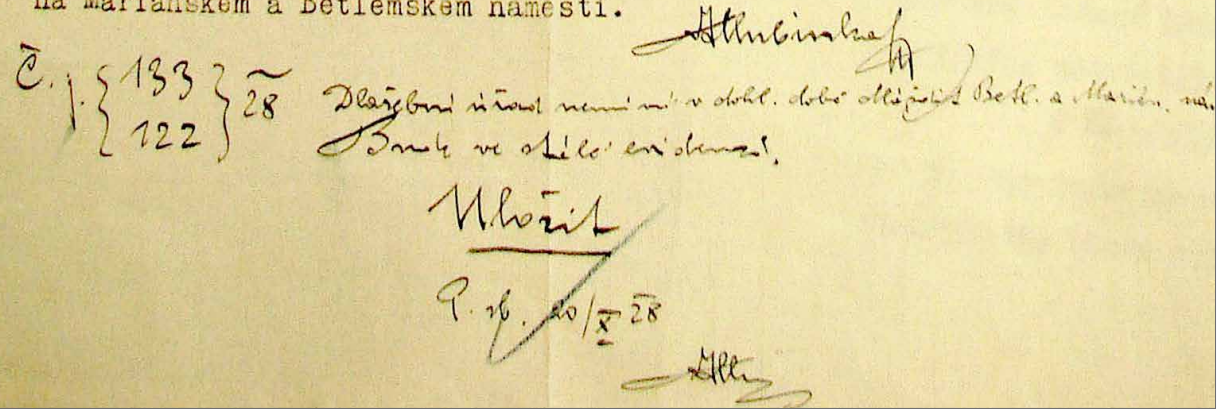

Obr. 3. Výpis ze zápisu schůze Památkového sboru týkající se informací ohledně požadovaných výzkumů před úpravami povrchů prostranství v místech zaniklých sakrálních staveb. Zdroj AMP, MHMP, fond Památkový sbor, kart. 15, inv. č. 22.

Abb. 3. Auszug aus dem Sitzungsprotokoll des Denkmalbeirats bzgl. Informationen über geforderte Grabungen an Stellen untergegangener Sakralbauten vor der Oberflächengestaltung von Freiflächen. Quelle AMP, MHMP, Bestand Denkmalbeirat, Karton 15, Inv.-Nr. 22. 


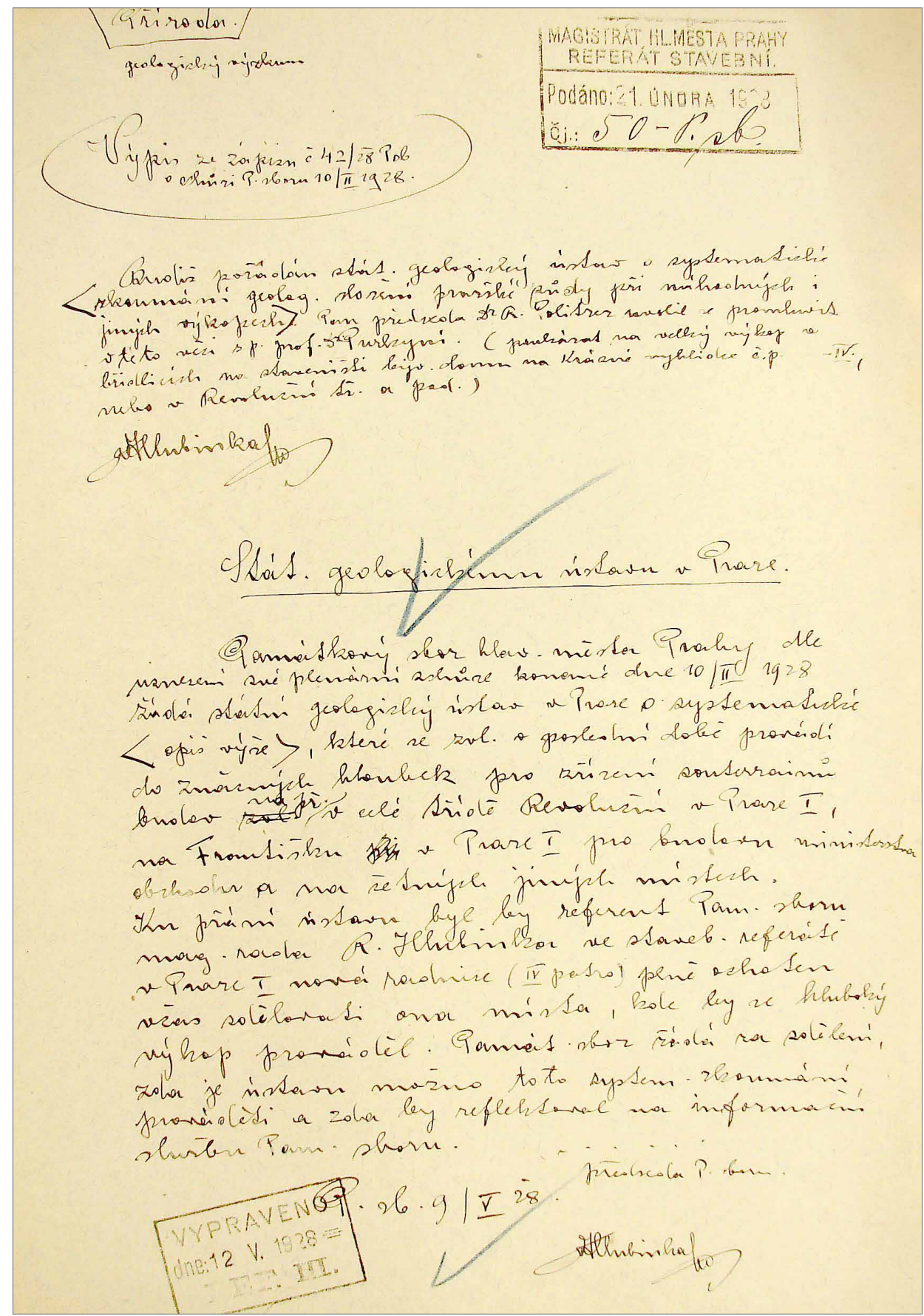

Obr. 4. Podnět R. Hlubinky vyplývající z usnesení Památkového sboru, na jehož základě měl být Státní geologický ústav vyzván magistrátem k systematickému sledování geologické situace ve stavebních výkopech. Zdroj AMP, MHMP, fond Památkový sbor, kart. 17, inv. č. 30.

Abb. 4. Aus einem Beschluss des Denkmalbeirats hervorgehende Anregung von R. Hlubinka, aufgrund dessen das Staatliche geologische Institut vom Magistrat aufgefordert werden soll, die geologische Situation in den Baugruben systematisch zu beobachten. Quelle AMP, MHMP, Bestand Denkmalbeirat, Karton 17, Inv.-Nr. 30. 
pozůstalosti. Za zcela výjimečné je pak možné označit jeho úspěšné úsilí o záchranu a prezentaci archeologických památek - především reliktů románských objektů objevených při stavbě Nové radnice (mezi lety 1926 a 1929; obr. 5-7). Nevzpomenout nelze ani dlouhodobé snahy o uchování a částečnou prezentaci domu Tychona Brahe na Hradčanech (např. ještě pro rok 1946 archiválie

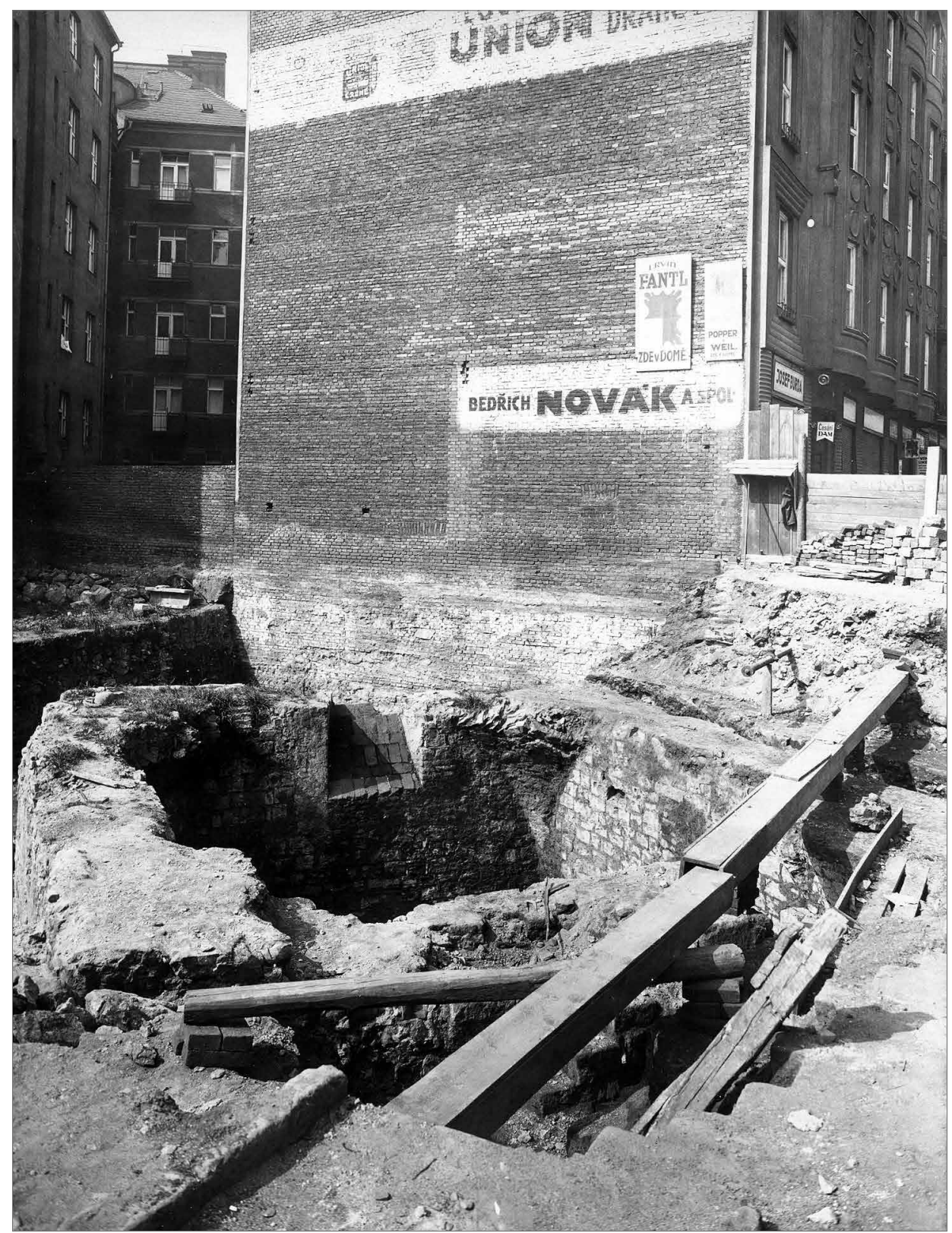

Obr. 5. Praha 1, Staré Město, Kaprova - Platnéřská. Odhalené pozůstatky románského kvádříkového domu čp. 31. Památkový sbor, A2622A, foto J. Pasternak, 29. 8. 1926. Zdroj ARÚ Praha, pozůstalost I. Borkovského.

Abb. 5. Prag 1, Altstadt, Straßen Kaprova - Platnéřská. Freigelegte Überreste des romanischen Werksteinhauses Konskriptionsnr. 31. Denkmalbeirat, A2622A, Foto J. Pasternak, 29. 8. 1926. Quelle ARÚ Prag, Nachlass von I. Borkovský. 


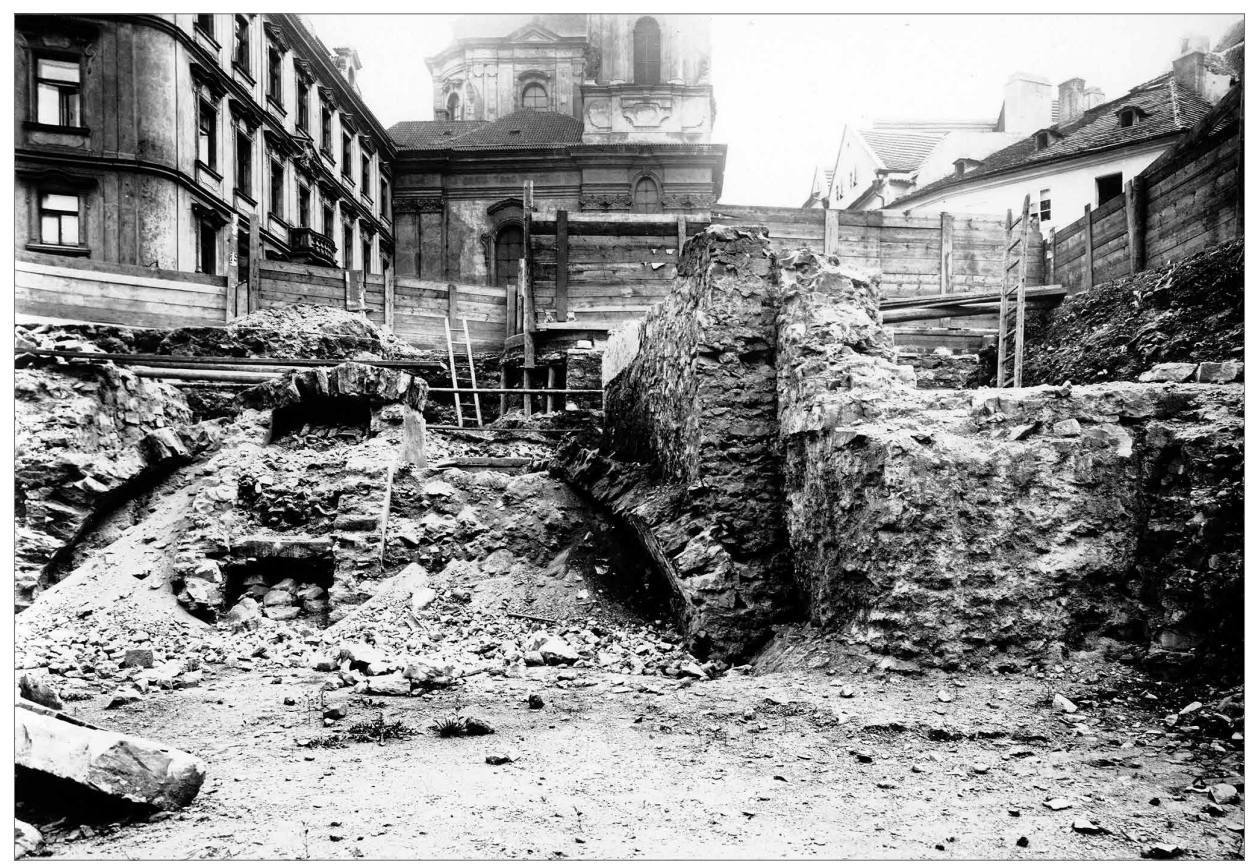

Obr. 6. Praha 1, Staré Město, Kaprova - Platnéřská. Situace výkopu pro novou radniční budovu s pozůstatky románského přízemí bývalého domu čp. 16. Pohled směrem ke kostelu sv. Mikuláše a Staroměstskému náměstí. Památkový sbor, A2620B, foto J. Pasternak, 29. 8. 1926. Zdroj ARÚ Praha, pozůstalost I. Borkovského.

Abb. 6. Prag 1, Altstadt, Straßen Kaprova - Platnéřská. Situation der Baugrube für das neue Rathausgebäude mit Überresten des romanischen Erdgeschosses des ehemaligen Hauses Konskriptionsnr. 16. Blick in Richtung Nikolauskirche und Altstädter Ring. Denkmalbeirat, A2620B, Foto J. Pasternak, 29. 8. 1926. Quelle ARÚ Praha, Nachlass von I. Borkovský.

dokládají urgování zabezpečení a překrytí reliktů domu archeologicky odkrytých již v roce 1931, a to alespoň lepenkou) nebo snahu o záchranu reliktů malostranského biskupského dvora, zkoumaného v letech 1928-1929, či výjimečný př́ípad přenesení torza románského domu z Hradčanského náměstí do prostor Pražského hradu, které Hlubinka inicioval v roce 1944 společně se Z. Wirthem (AMP, MHMP, fond Památkový sbor, kart. 17, inv. č. 31; ÚDU, H 9/6; Hlubinka 1931; APH, Ss II/41).

Z hlediska významu pro studium nejen kulturního dědictví, ale i dokumentace proměn Prahy a jejího zázemí, lze za mimořádně významnou označit i Hlubinkovu činnost v oblasti dokumentární fotografie, at' již se této otázce věnoval po stránce organizační, či pořizoval snímky sám, dokumentace se týkala jak historického jádra Prahy, tak mizejících památek na tehdejší periferii rozrůstajícího se města (podrobně Přikrylová 2017). Dbal na systematickou fotografickou dokumentaci nejen památek archeologizovaných a stavebních, ale zajištoval rovněž snímky mizející kulturní krajiny na hranicích tehdejší Prahy. V období války po útlumu stavebních prací v květnu 1942 se soustředil právě na dokumentaci zázemí Prahy nebo na pořádání archivu fotografií (AMP, MHMP, fond Památkový sbor, kart. 15, inv. č. 22). V poválečných letech systematicky vyhledával další fotografie Prahy a jejího okolí u řady institucí (Vojenský zeměpisný úřad, Hlavní štáb velitelství letectva, plánovací referát ÚNV hl. m. Prahy), které oslovoval s žádostí o jejich předání či alespoň pořízení kopií (AMP, MHMP, fond Památkový sbor, kart. 16, inv. č. 25). Při rekapitulaci stavu fotodokumentace Památkového sboru konstatuje, že z ca 45000 fotografií a negativů téměř 20000 kusů shořelo při požáru Staroměstské radnice na sklonku války (AMP, MHMP, fond Památkový sbor, kart. 15, inv. č. 22).

Již letmý pohled na inventář Hlubinkovy pozůstalosti odkrývá jeho komplexní přístup k pražské problematice, který se jednoznačně odráží v širokém spektru témat, které archiválie 


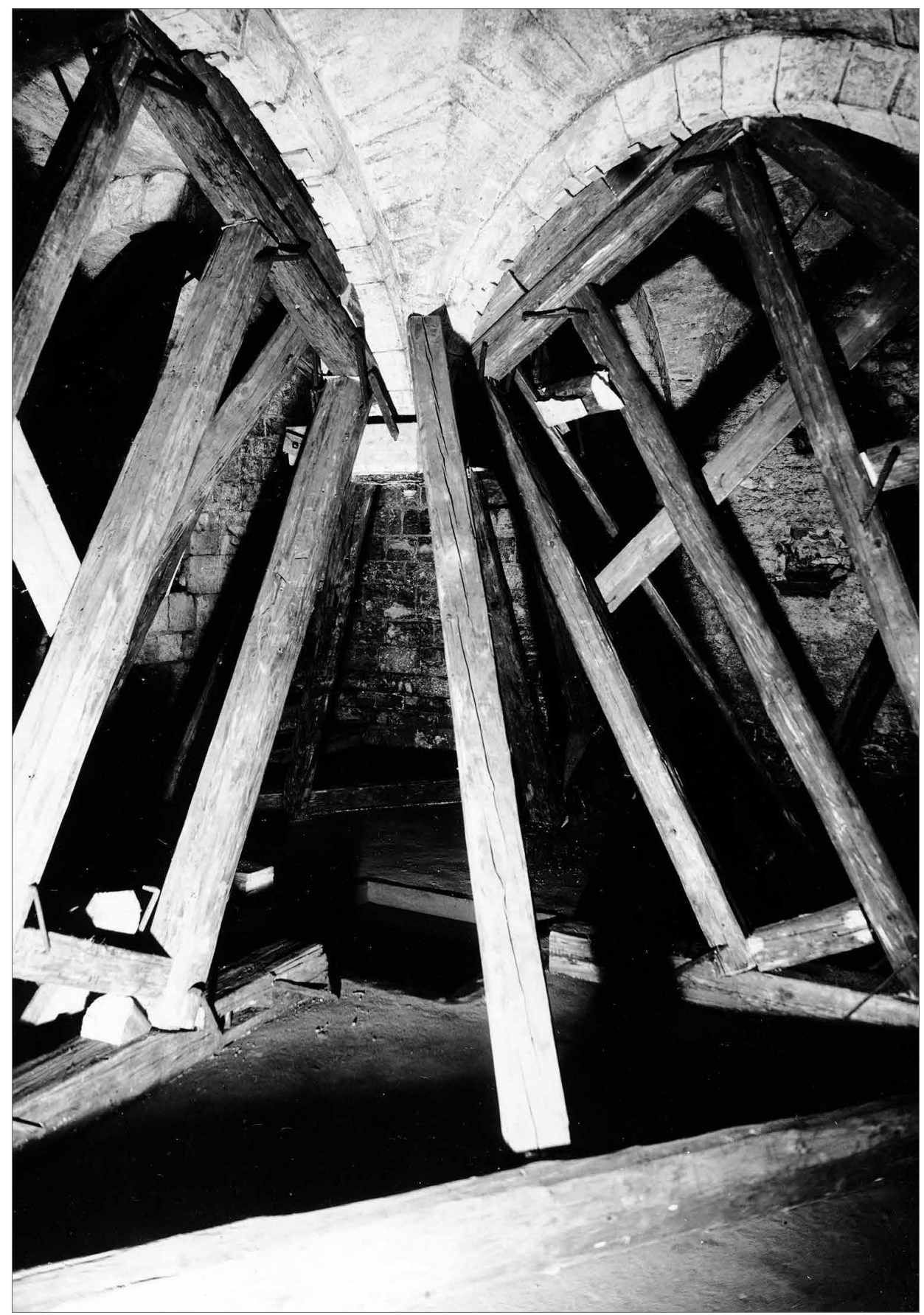

Obr. 7. Praha 1, Staré Město, Kaprova - Platnéřská, někdejší suterény zaniklého čp. 16. Ukázka lešení postaveného B. Kabátem po odstranění původního poškozeného románského sloupu před instalací jeho repliky. Památkový sbor, 12447A, 3. 11. 1938. Zdroj ARÚ Praha, pozůstalost I. Borkovského.

Abb. 7. Prag 1, Altstadt, Straßen Kaprova - Platnéřská, ehemalige Souterrains der untergegangenen Konskriptionsnr. 16. Nach Beseitigung der ursprünglichen, beschädigten romanischen Säule vor deren Replik von B. Kabát aufgebautes Gerüst. Denkmalbeirat, 12447A, 3. 11. 1938. Quelle ARÚ Praha, Nachlass von I. Borkovský. 
zachycují. Vedle již zmíněných staveb sakrálních (ÚDU, H 7/1, 2; kostely i kláštery včetně v meziválečném období zkoumaného kláštera ostrovského již mimo pražské území) mezi nimi nechybí ani problematika pražských raně středověkých hradišt' včetně blízkého Levého Hradce (ÚDU, H 7/3) či shromažd’ování podkladů k dosud málo detailně poznaným tématům pražských raně stř̌edověkých osad obklopujících opevněné jádro pražské aglomerace (ÚDU, H 7/1) či dokonce mlýnů (ÚDU, H 7/3).

Samostatnou kapitolu v oblasti širokých aktivit R. Hlubinky představuje studium pražských románských domů - jejich evidence i dokumentace. Dokumentace nejstarší měšt’anské zástavby na území Starého Města byla $\mathrm{z}$ dnešního úhlu pohledu zásadním úkolem nově se formující památkové péče. Z materiálů Památkového sboru koncipovaných R. Hlubinkou je patrná snaha zajistit všestrannou péči o doklady pražské minulosti včetně jejich výzkumu a shromažd'ování „vědeckých pomůcek" - tj. jejich fotodokumentace, zaměřování i publikace. Fenomén profánní zástavby románské Prahy se stal pro R. Hlubinku životním tématem. Byl si vědom mimořádného významu do té doby jen náhodně evidovaných objektů budovaných z románského kvádř́kového zdiva a od počátku 20. let se s velkým nasazením ujal cíleného vyhledávání těchto staveb, jejich evidence a dokumentace. Díky své pozici vlivného úředníka na stavebním referátu pražského magistrátu a jednatele Památkového sboru měl možnost provádět z ,pozice úředni“" prohlídky pražských historických domů a sklepení. Jak sám uvádí: „Velmi brzo se ukázalo, jak se obě tyto funkce doplňovaly a vzájemně si znamenitě napomáhaly (...)“(Hlubinka 1947, 28). Již v roce 1921 se mu podařilo zjistit první dosud neznámé románské prostory v domech po obvodu Staroměstského náměstí - čp. 478, 479 a následně v domě čp. 147 na nároží Jilské a Karlovy ulice. V průběhu 20. a 30. let se jeho zájem soustředil na další objekty na Malém náměstí, v Celetné, Kaprově, Řetězové, Husově a Jilské ulici a v blízkém okolí. Během sedmnáctiletého působení tak postupně nalezl a zdokumentoval 25 objektů uvedeného typu (Hlubinka 1947; obr. 8). Pro jejich poznání měla zásadní význam Hlubinkou prováděná a organizovaná operativní dokumentace spočívající v zaměření a fotodokumentaci románského prostoru. Ve fondu Rudolfa Hlubinky uloženém v pražském ÚDU se dochovaly rukopisné záznamy několika popisů nálezových situací vybraných románských domů. Důraz zde kladl na půdorysnou skicu objektu s vyznačením a popisem

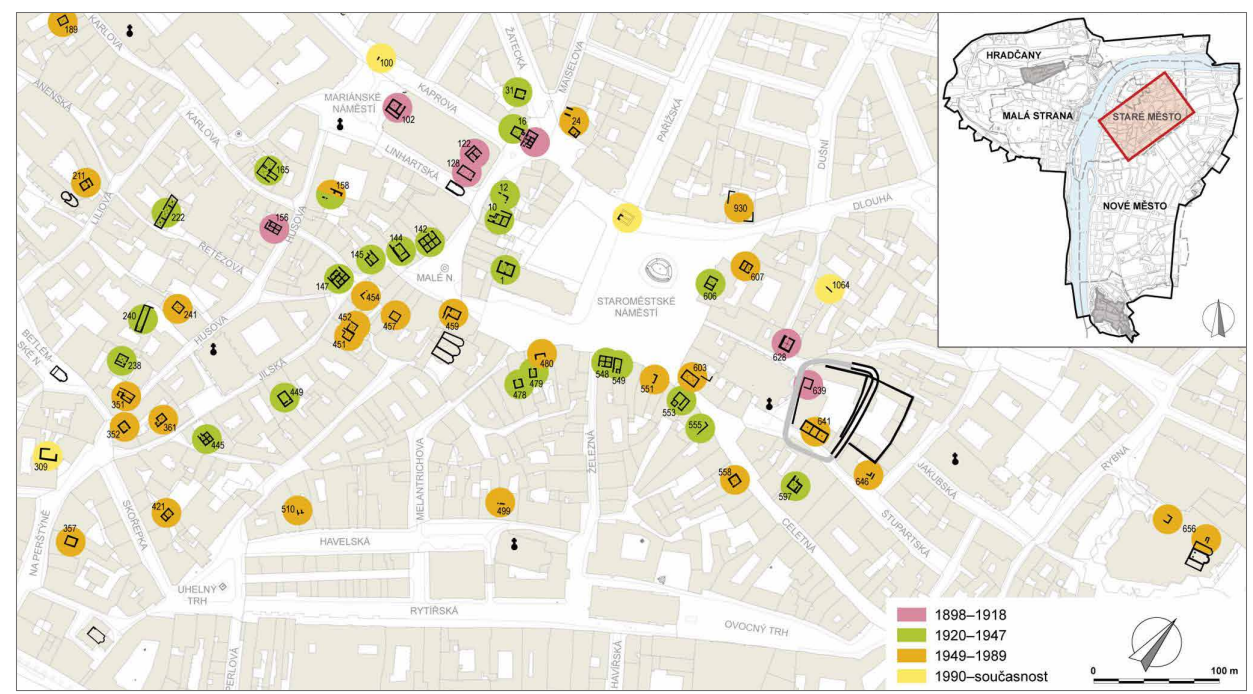

Obr. 8. Praha 1, Staré Město (výřez). Plán pozůstatků románských domů a jejich konstrukcí zjištěných a dokumentovaných od r. 1898 až do současnosti. Podle podkladů J. Podlisky graficky zpracovala $S$. Babušková.

Abb. 8. Prag 1, Altstadt (Ausschnitt). Planskizze der Überreste romanischer Häuser und ihre festgestellten und dokumentierten Konstruktionen von 1898 bis zur Gegenwart. Nach Unterlagen von J. Podliska graphisch bearbeitet von S. Babušková. 
jednotlivých stavebních struktur. Zaznamenávány jsou například rozměry kvádříků, typy a další charakteristické znaky kleneb či jednotlivých prostor, pozornost je věnována různým detailům, které lze při běžném pozorování přehlédnout, například vyrytým značkám či nápisům. I to svědčí o pečlivosti, s níž R. Hlubinka tyto průzkumy prováděl. Popis byl vždy provázán s odkazy na tehdy provedenou fotodokumentaci. ${ }^{1}$ Svou pozornost vedle stavebních částí věnoval mimo jiné i jejich typologii, situování objektů v rámci stávající parcelace, umělecké výzdobě a rámcovému datování. Výsledky své práce prvně představil již v roce 1938 na výstavě pravěké a románské Prahy. V průběhu své aktivní činnosti si uvědomoval mimořádný význam souboru těchto objektů, vyzdvihoval jejich „(...) velkou kulturni hodnotu, dokumentujici význam a výstavnost [středověké] Prahy (...)“ a zdůrazňoval potřebu jejich veřejné (muzejní) prezentace i za cenu ,„...) sebevětšich nákladü“, aby se „(...) zachovaly (...) jako neklamní svědkové i na dalši dlouhá staleti“" (Hlubinka 1947, 46). Přes penzionování v témže roce pokračoval ve své badatelské práci i během válečných let. V roce 1941 objevil jednu z nejcennějších románských staveb - trojprostorový patrový dům palácového typu v Řetězové ulici čp. 222 (Hlubinka 1947, 40-41). Jeho věcně a systematicky pojatý katalog románských domů doplněný o půdorysy nalezených domů a fotografie interiérových situací se na dlouhou dobu stal základem pro budoucí studium, ve kterém, jak sám uvedl, „(...) by se mělo intensivně a systematicky pokračovat kolektivni praci odborniků soustředěných v kanceláŕi Památkového sboru (...)“ (Hlubinka 1947, 46). Jedním z prvních badatelů, který velice záhy využil četné Hlubinkovy poznatky, byl pražský archivář Jiří Čarek. Ten je s několika př́klady převzaté dokumentace pořizované Památkovým sborem prezentoval široké veřejnosti ve své monografii Románská Praha (Čarek 1947). ${ }^{2}$

Událostí mimořádného významu bylo určitě, a to nejen z hlediska historického, ale v tíživé atmosfére konce 30 . let i z hlediska celospolečenského, uspořádání výstavy, která prostřednictvím významných archeologických nálezů představovala veřejnosti bohatou pražskou minulost. Jejím stěžejním tématem byla, jak vyplývá z archiválií v Hlubinkově pozůstalosti (koncepty, soupisy exponátů), románská Praha (ÚDU, H 7/4), tedy téma jemu vlastní. Výstava byla instalována v pražském Uměleckoprůmyslovém muzeu (3. 6. - 30. 9. 1938). Jako organizátoři jsou vedle Památkového sboru uvedeny tyto instituce: StAÚ, Stavební správa Pražského hradu, Fotoměřický ústav a Uměleckoprůmyslové muzeum. Záběr výstavy byl oficiálně širší a z dochovaných dokumentů plyne, že byla uspořádána $\mathrm{v}$ souvislosti se zasedáním mezinárodního výboru pro dějiny umění, které se v daném termínu v Praze odehrálo. Ve výsledné instalaci ale dominoval zcela jednoznačně obraz raně středověké (románské) Prahy (pět kójí a šest vitrín oproti jedné kóji věnované pravěkým památkám). Vedle detailní dokumentace jednotlivých staveb (půdorysné plány, řezy, rekonstrukce, fotografie) byly prezentovány celkové plány Prahy s piktogramy představujícími rozmanitost sakrální i světské architektury, výsledky výzkumu obou hradních areálů i situace podhradního osídlení. V obecné rovině se dozvídáme i o existenci modelů památek.

Mezi vize R. Hlubinky, logicky vyplývající ze šíre jeho aktivit, náleží i záměr zřízení speciální instituce zaměřené na studium Prahy - dle koncepce z roku 1945 komplexně pojatého Ústavu památkové péče pro Prahu a okolí (AMP, MHMP, fond Památkový sbor, kart. 26; ÚDU, H 7/8-1), který v historickém kontextu závěru Hlubinkova působení neměl již reálnou možnost uspět. Nelze pominout skutečnost, že stejně jako některé další z jednotlivých položek koncepce archeologického výzkumu Prahy v meziválečném období se obdobná myšlenka čas od času mezi badateli zabývajícími se minulostí Prahy vynoří, aniž je zřejmé, zda primárně vychází z Hlubinkova myšlenkového odkazu, či v tomto případě z logické potřeby komplexního př́ístupu ke studiu geneze tak složitého organismu, jaký metropole našeho státu představuje.

\footnotetext{
1 Lze předpokládat, že tyto fotografie jsou součástí fotografické sbírky AMP, jejich duplicitní verze pak mohou být uloženy jak ve fototéce archivu ÚDU, kam byly dle sdělení pracovníků odd. dokumentace fotografie z Hlubinkovy pozůstalosti předány, tak v některé z dalších institucí, které se na dokumentaci historických objektů podílely. Vzhledem k aktuálně probíhajícímu procesu digitalizace sbírek většiny institucí není ověření existence konkrétních fotografií v současnosti reálné.

2 Hlubinkova pozůstalost obsahuje i kritickou reflexi této práce (rkp. poznámky s označením „Vady na Čarkově Románské Praze“; ÚDU, H 7/2).
} 


\subsection{Jaroslav Pasternak a jeho role}

Přínos archeologa ukrajinského původu (obr. 9) pro pražskou archeologii dosud nebyl zhodnocen. Jeho jméno zůstalo téměř zapomenuto, což lze přičíst zčásti na vrub toho, že jeho působení v Praze bylo krátkodobé (1923-1928), zčásti toho, že ani po absolutoriu (své předchozí studium na univerzitě ve Lvově završil doktorátem na FF UK v Praze v roce 1925) zde nebyl v plnohodnotném odborném postavení. Přitom mu byl od počátku svěřován dohled nad terénními výzkumy, což v praxi odpovídalo každodenní přítomnosti v terénu, a tedy reálnému vedení vlastních výzkumů. V rámci StAÚ byl zprvu veden jako volontér, posléze po absolutoriu jako asistent výzkumu. Během svého působení na Pražském hradě byl však podřízen vedení Karla Gutha a jeho plat byl StAÚ refundován Kancelárí prezidenta republiky. Řadu odkryvů v historickém jádru Prahy rovněž prováděl $\mathrm{v}$ režii Památkového sboru. V roce 1926 mu město Praha na doporučení Památkového sboru přidělilo domovské právo, nezbytné pro jeho přijetí do státního

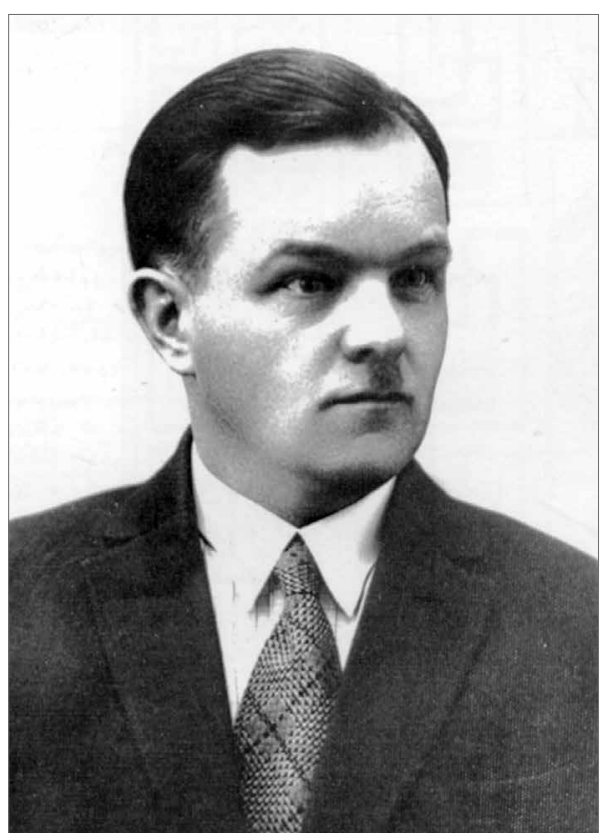

Obr. 9. Jaroslav Pasternak. Za zprostředkování portrétní fotografie jsme zavázáni I. Prohnenkovi (UA).

Abb. 9. Jaroslav Pasternak. Für die Vermittlung der Porträtfotografie sind wir I. Prohnenko verbunden (UA). služebního poměru. K 27. březnu 1928 podává R. Hlubinka na MHMP koncept osvědčení pro J. Pasternaka, jehož vážnost dokresluje formulace, že jmenovaný se „(...) při všem plně osvědčil (...)“ a „ovládá dokonale moderní vědeckou metodu pro historické výkopy v každém rozsahu“. Přes nesporné a obecně př́slušnými autoritami oceňované odborné kvality se však J. Pasternak zřejmě již v roce 1928 vrátil na Ukrajinu, odkud však v roce 1944 emigroval. Přednášel na univerzitách v Bonnu a Mnichově, od roku 1950 dlouhodobě působil v Kanadě, kde se jeho životním tématem stala prehistorie Ukrajiny.

Podle dosavadních poznatků o jeho působení v Praze lze s jeho jménem spojovat především výzkum 3. nádvoří Pražského hradu (1925-1928). K dalším významným aktivitám náleží odkryvy a dokumentace románských domů v budoucí ploše budovy nové radnice mezi ulicemi Kaprova a Platnéřská (1926) a v interiéru kostela sv. Václava na Zderaze (1927-1928?). Z drobných záchranných akcí pak připomeňme nález hrobů Na Slupi (1926) a sondáž na Strahově (1926), podle zprávy J. Müllera se podílel i na výzkumu Vyšehradu. Z mimopražských aktivit lze uvést účast na výzkum v Libušíně v gesci ARÚ (1924; MÚA, fond 27, kart. 1). Vedle terénních prací lze $\mathrm{v}$ dochovaných archiváliích vystopovat i jeho podstatný podíl na fotodokumentaci dalších výzkumů.

Za zcela zásadní lze označit jeho působení na výzkumu 3. nádvoří Pražského hradu (obr. 10). Oficiálně byl zajištěním výzkumu pověřen StAÚ společně s Národním muzeem a pro jeho řízení byla sestavena meziinstitucionální komise v čele s K. Guthem (v letech 1926-1943 vedoucím historicko-archeologického odd. Národního muzea). Reálně J. Pasternak již jako asistent StAÚ vedl terénní část výzkumu od jeho počátku v roce 1925 do března 1928. Od počátku tohoto roku postupně předával agendu v laboratoři a posléze $s$ menší přestávkou i výzkum včetně dokumentace I. Borkovskému (Pasternak 1928, 753, 775; poslední Pasternakův záznam v terénním deníku nese datum 27. 3. 1928; shoda mezi datem, kdy Pasternak opouští Pražský hrad, a datem vydání jeho osvědčení Pražským památkovým sborem není nejspíše náhodná, může souviset 


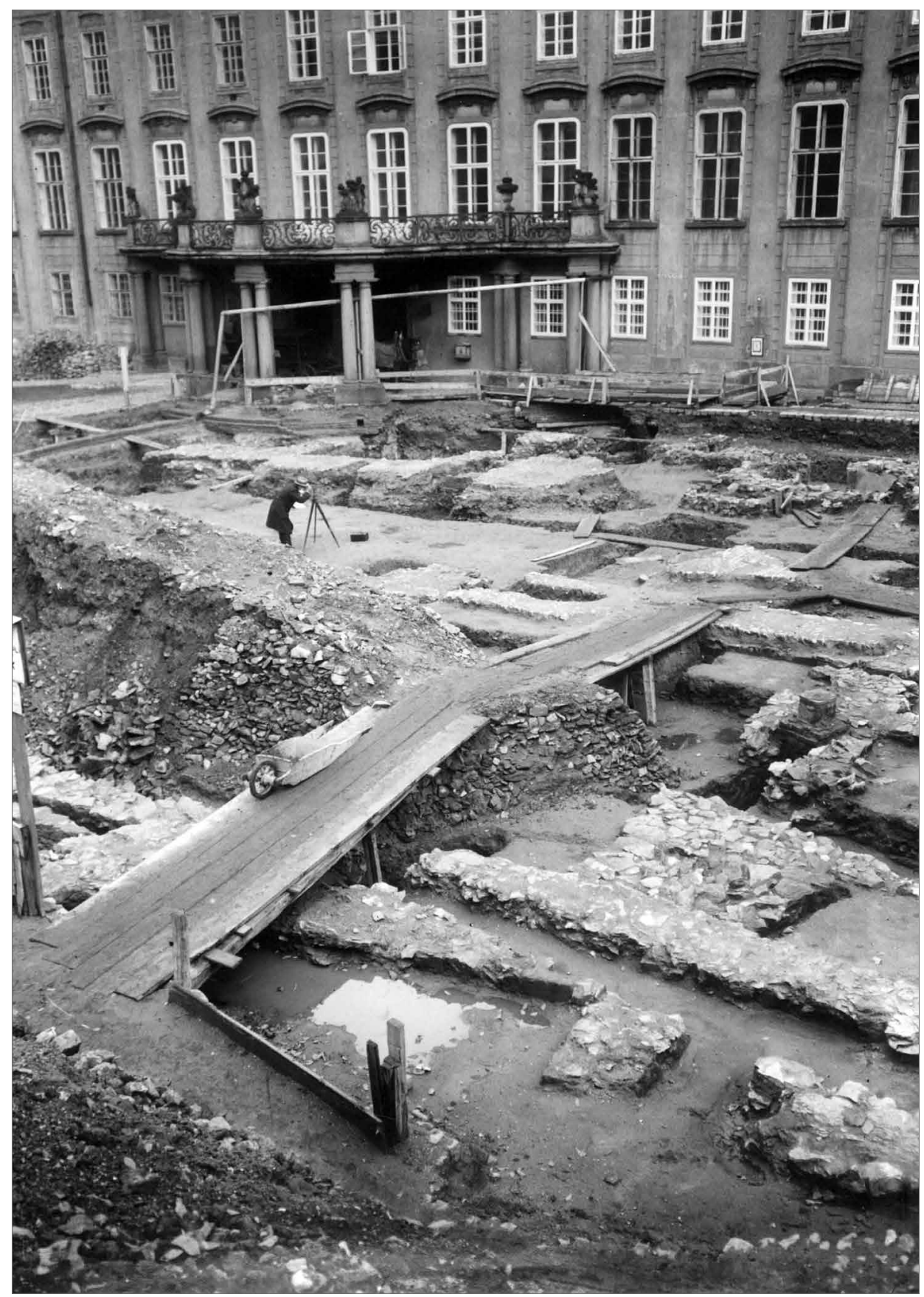

Obr. 10. Pražský hrad, 3. nádvoří, 25. října 1926. Celkový pohled na výzkum na 3. nádvoří od severozápadu zachycuje krom korun zdiv a částečně snížených terénů v jihozápadní části nádvoří fotografa dokumentujícího aktuální stav výzkumu (konkrétní osobu se identifikovat nepodařilo). Foto J. Pasternak, č. 314. Zdroj ARÚ Praha, pozůstalost I. Borkovského.

Abb. 10. Prager Burg, 3. Hof, 25. Oktober 1926. Die Gesamtansicht der Grabung auf dem 3. Hof aus Nordwesten zeigt außer der Mauerkrone und den teilweise tiefergelegten Geländen im südwestlichen Teil des Hofes den Fotografen, der den aktuellen Zustand der Grabung dokumentiert (die konkrete Person konnte nicht identifiziert werden). Foto J. Pasternak, Nr. 314. Quelle ARÚ Praha, Nachlass von I. Borkovský. 
i s jeho odchodem na Ukrajinu, informace o závěru jeho působení v Praze se však nepodařilo dohledat).

Zřejmě od roku 1926 byl výzkum 3. nádvoří plně podřízen K. Guthovi (MÚA, Státní archeologický ústav, fond 27 , kart. 2 ). ${ }^{3} \mathrm{~K}$. Guth navštěvoval výzkum pravidelně a poměrně často, na vlastních terénních pracích se ale nijak výrazněji nepodílel. Zmínky o tom, že K. Guth přímo $\mathrm{v}$ terénu řešil některá témata, jsou v Pasternakových zápiscích zcela výjimečné. Naopak význam Pasternakova angažmá při terénním výzkumu dokládají sporadické záznamy o tom, že v době Pasternakovy ojedinělé nepř́ítomnosti jej K. Guth zastupoval (např̀. Pasternak 1927, 559). Guthovy zápisky k výzkumu na 3. nádvoří jsou uloženy v jeho nově uspořádaném osobním fondu v Archivu Národního muzea (ANM, Nad 156, inv. č. 556-583). Ze srovnání těchto zápisků s deníky ovšem jednoznačně vyplývá, že Guth psal své zápisky dodatečně právě na základě Pasternakových deníkových záznamů (odkazy na data i vyobrazení, konkrétní pojmy i číselné údaje), možná i se značným odstupem od výzkumu (není datováno). Nejde v žádném případě o dokumentaci primární, ale již o souhrn údajů k jednotlivým plochám výzkumu, a to nejspíše za účelem jejich vyhodnocení.

Deníkové záznamy J. Pasternaka, které $\mathrm{v}$ dokumentaci $\mathrm{z}$ výzkumu mezi lety 1925-1928 zcela jednoznačně převažují (v roce 1925 se objevují zrrídka a v letech následných zcela sporadicky také záznamy J. Filipa a J. Böhma), obsahují popis odkrývaných situací včetně skic, zhotovovaných většinou $\mathrm{v}$ měřítku $1: 20$. Lze $\mathrm{z}$ nich spolehlivě odvodit používanou metodu terénních prací. Dikce zápisů i pořízená dokumentace (deníkové skici a také některé fotografie) dokládají, že historické terény byly rozebírány po přirozených vrstvách. ${ }^{4} \mathrm{~V}$ deníku Pasternak často píše o ,stopování povrchü“ rozlišených stratigrafických jednotek. Průběžně zaznamenával klíčové stratigrafie pomocí skic, v nichž vrstvy označoval písmeny. Popisy vrstev obsahují základní charakteristiku a rámcové datování horizontu, k němuž náležely, stanovené intuitivně podle zaznamenaných změn $\mathrm{v}$ keramickém inventáři. Pro jednotlivé horizonty byly užity obecně srozumitelné pojmy vztažené $\mathrm{k}$ historickým etapám: ,spodni a svrchni románský terén, karolinský terén, renesančni terén, Břetislavská hradba" (obr. 11-17). V textech jsou pak udávána tato období i v datech absolutní chronologie. Konfrontujeme-li Pasternakovo uváděné datování s dnešními poznatky o vývoji pražské středověké keramiky, dospíváme

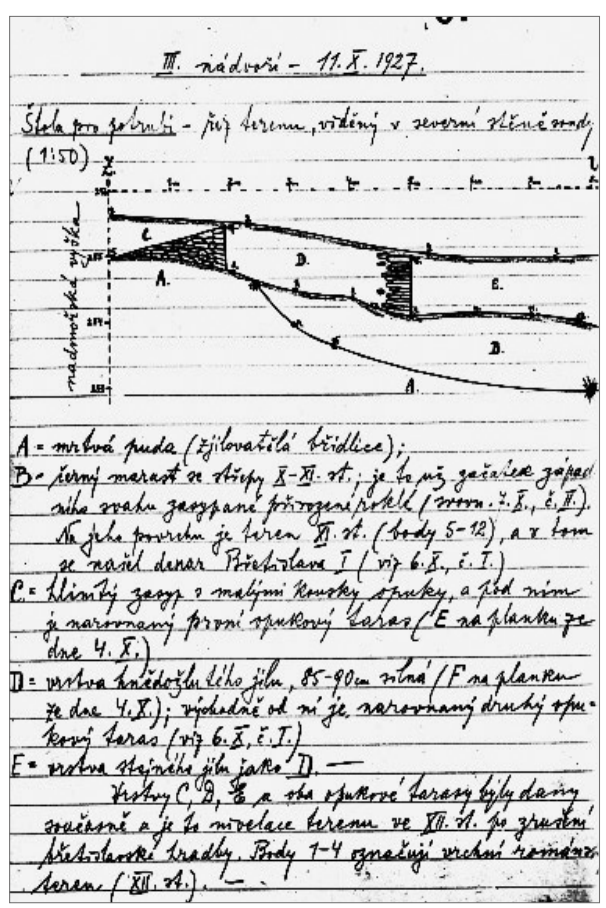

Obr. 11. Pražský hrad, 3. nádvoří. Ukázka záznamu terénní situace z 11. října 1927 - skica řezu s popisem vrstev. Podle Pasternak 1927, 670.

Abb. 11. Prager Burg, 3. Hof. Beispiel einer Aufzeichnung der Geländesituation vom 11. Oktober 1927 - Skizze des Schnitts mit Beschreibung der Schichten. Nach Pasternak 1927,670 .

\footnotetext{
3 Vyplývá to z dopisu ředitele StAÚ K. Buchtely, adresovaného MŠANO v roce 1937. Sdělení upřesňuje pozici I. Borkovského na výzkumu 3. nádvoři Pražského hradu. „Výkopni komise“ se na výzkumu podle evidence v denících scházela zcela nepravidelně, nepř́liš často a také v různých formátech. Vedle poměrně hojně zaznamenávané prrítomnosti K. Gutha se nejčastěji objevuje jméno hradního stavitele K. Fialy, několikrát ročně jsou vesměs zmiňovány návštěvy K. Buchtely.

4 Samozřejmě nelze výzkum posuzovat z hlediska dnešních nároků na detailní evidenci všech stratigrafických jednotek a jejich vztahů, ale v kontextu doby a praxe tehdy běžné. Metody terénní práce, které Pasternak, alespoň pokud jde o tento výzkum, používal, její nároky výrazně převyšovaly. Rovněž je však třeba brát v úvahu, že na odkryvech se podle deníkových záznamů podílelo často několik desítek pracovníků současně, a lze předpokládat, že rozebírání terénů po přirozených vrstvách nemohlo být uplatňováno celoplošně.
} 


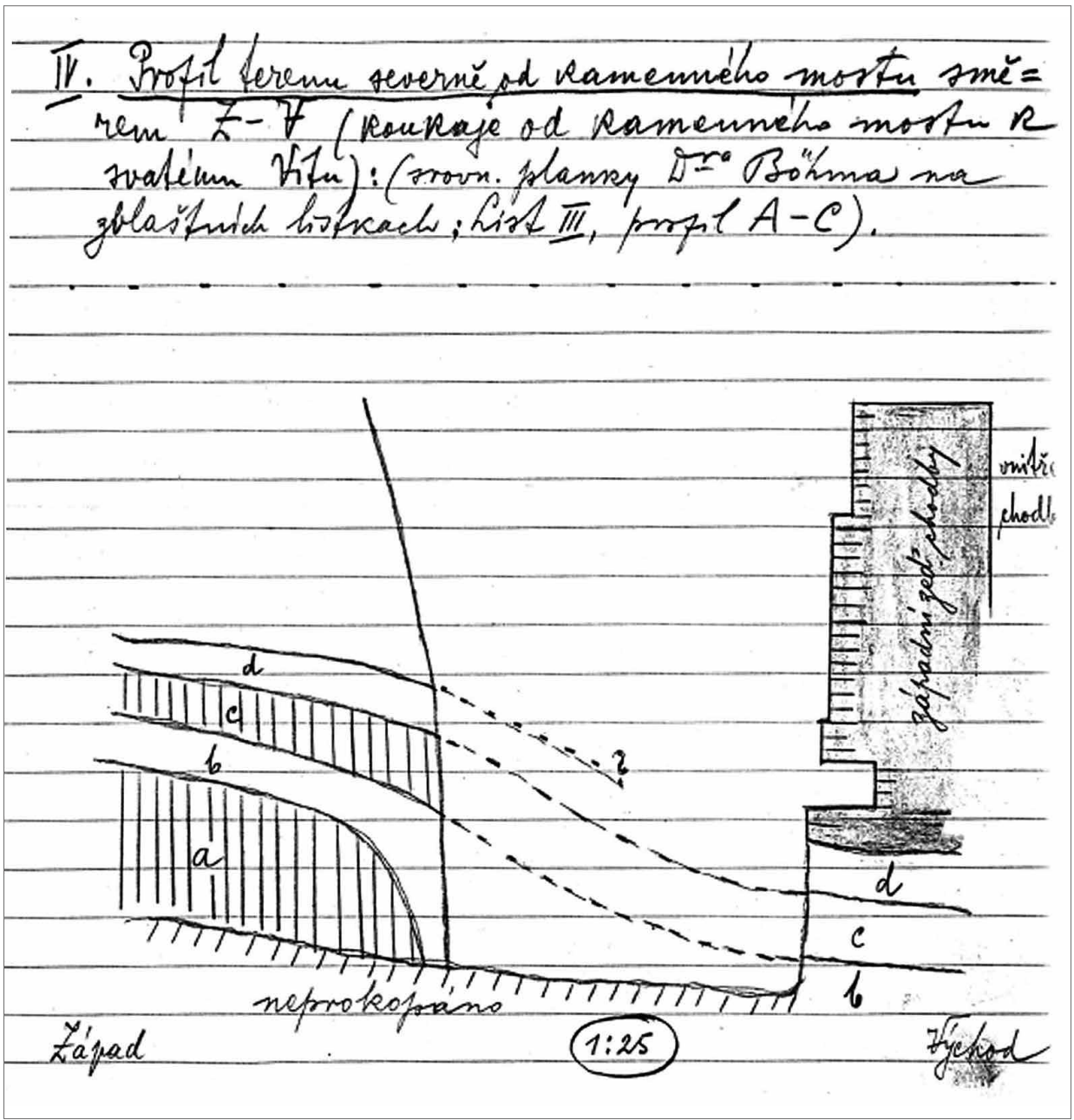

Obr. 12. Pražský hrad, 3. nádvoří, 20. října 1926. Skica řezu souvrstvím, uloženým před výstavbou románské chodby na západním svahu tzv. jižní rokle. Podle Pasternak 1925, 249.

Abb. 12. Prager Burg, 3. Hof, 20. Oktober 1926. Skizze des Schnitts durch die Schichtenfolge, die sich vor dem Bau des romanischen Gangs am Westhang der sog. Südschlucht ablagerte. Nach Pasternak 1925, 249.

k závěru, že tehdejší rámcová a víceméně intuitivní chronologie se výrazně od současného datování základních keramických horizontů neliší, ačkoliv v mezidobí došlo k určitým posunům datace některých typů keramiky. Spodní románský terén zahrnuje keramiku staršího mladohradištního a ojediněle i středohradištního období (tj. keramiku s kalichovitými okraji a starší), svrchní románský terén mladší keramiku mladohradištní (horizont zduřelých okrajů v celé jejich škále), karolínský terén tvoří souvrství s keramikou vrcholného středověku. Zda a jak byl shora omezen renesanční terén, nebylo stanoveno. Ve srovnání s dnešním stavem poznání nalézáme rozpor pouze v označení „Břetislavská hradba“, které bylo užíváno pro mladší fázi dřevohliněného opevnění, jejíž výstavba ale, podle dendrodat získaných z výztuže hradby (Boháčová 2001), náleží druhé třetině 10. století. Kromě popisu odkrývaných situací zachycují Pasternakovy deníkové záznamy i některé další skutečnosti. Kromě informací o př́itomnosti členů komise a návštěvách širokého spektra dalších osobností (kromě prezidenta Masaryka např. jeho dcery Alice, J. Plečnika, dalších 


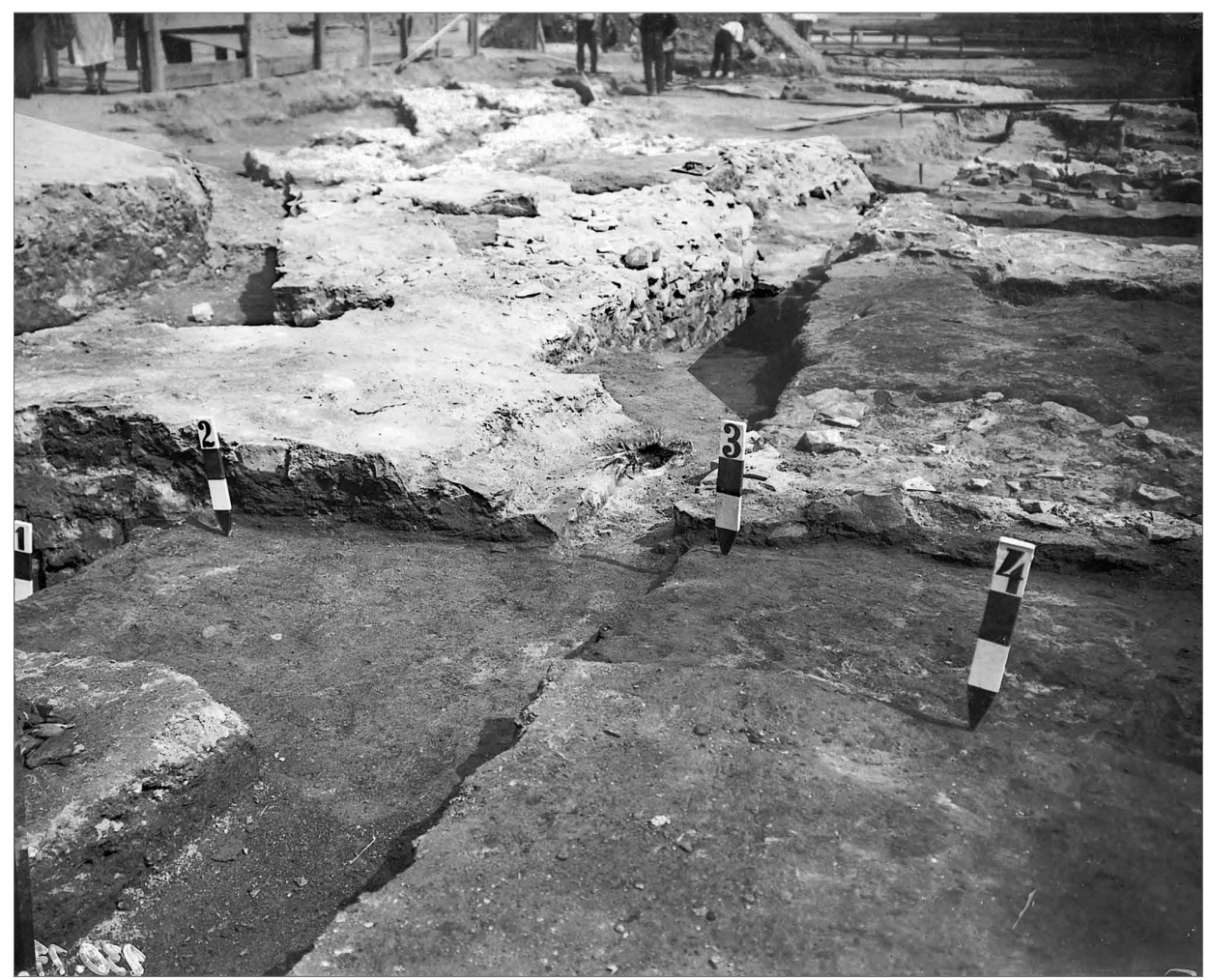

Obr. 13. Pražský hrad, 3. nádvoří, 2.-3. září 1926. Snímek povrchu s označením jednotlivých rozlišených kulturních horizontů, foto J. Pasternak. Zdroj ARÚ Praha, FT000103178-178A.

Abb. 13. Prager Burg, 3. Hof, 2.-3. September 1926. Aufnahme der Oberfläche mit Kennzeichnung der einzelnen unterschiedenen Kulturhorizonte, Foto J. Pasternak. Quelle ARÚ Praha, FT000103178-178A.

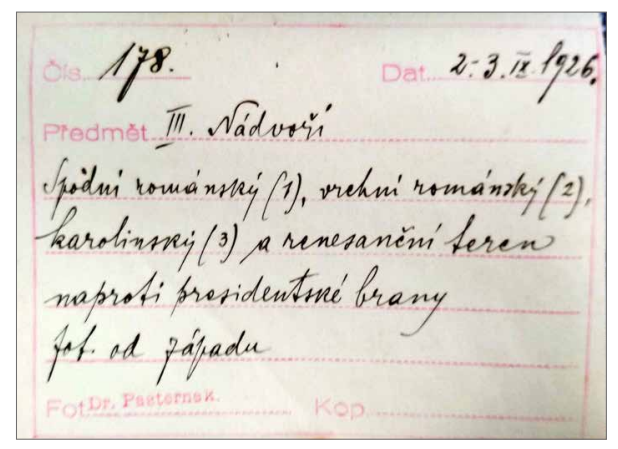

Obr. 14. Pražský hrad, 3. nádvoří, 2.-3. září 1926. Pasternakův popis kulturních horizontů zachycených na snímku č. 178, zobrazeném zde na obr. 13. Zdroj AMP, fotografická sbírka.

Abb. 14. Prager Burg, 3. Hof, 2.-3. September 1926. Pasternaks Beschreibung der auf Aufnahme Nr. 178 festgehaltenen und hier auf Abb. 13. dargestellten Kulturhorizonte. Quelle AMP, Fotosammlung.

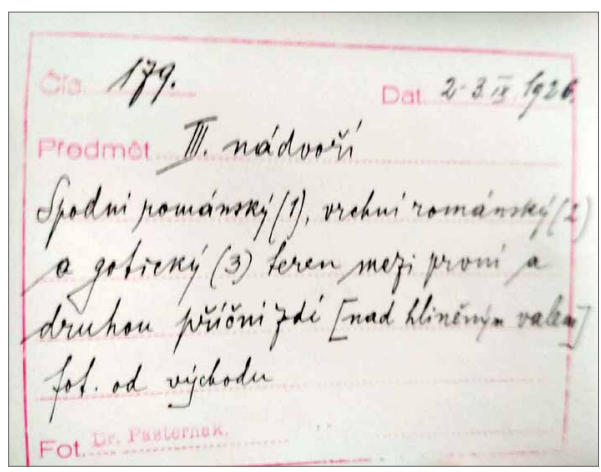

Obr. 15. Pražský hrad, 3. nádvoří, 2.-3. září 1926. Snímek č. 179 - další příklad Pasternakova popisu rozlišených kulturních horizontů z téhož dne. Zdroj AMP, fotografická sbírka.

Abb. 15. Prager Burg, 3. Hof, 2.-3. September 1926. Aufnahme Nr. 179 - ein weiteres Beispiel von Pasternaks Beschreibung der unterschiedenen Kulturhorizonte vom selben Tag. Quelle AMP, Fotosammlung. 


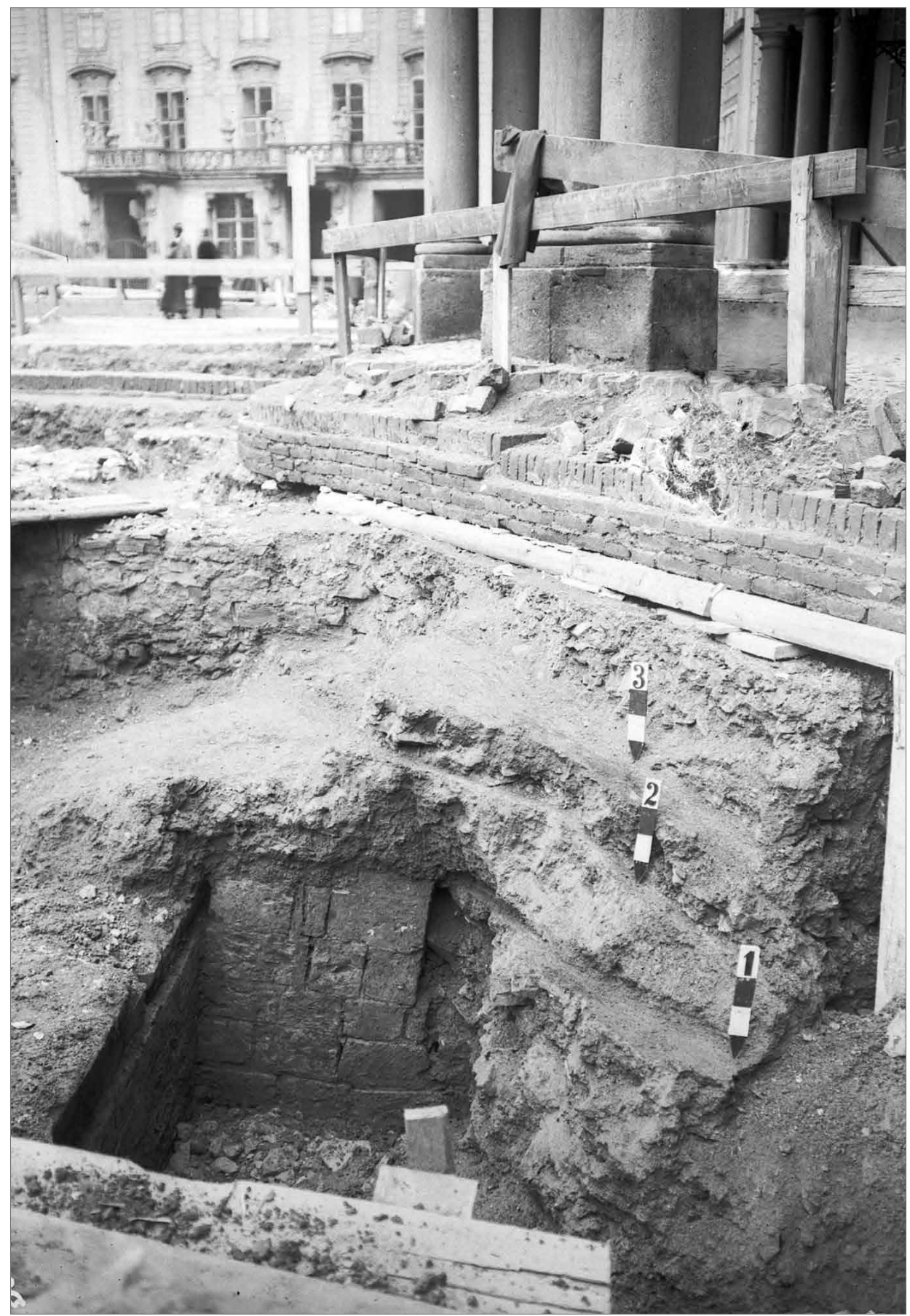

Obr. 16. Pražský hrad, 3. nádvoří, 29. září 1926. „Třetí hluboká sonda na povrchu valu před portálem F. III.“ Př́íklad postupného odkryvu terénů za vedení J. Pasternaka, foto J. Pasternak. Zdroj ARÚ Praha, FT000103256.

Abb. 16. Prager Burg, 3. Hof, 29. September 1926. „Dritter tiefer Sondierschnitt an der Walloberfläche vor Portal F. III.“ Beispiel einer schrittweisen Freilegung des Geländes unter Leitung von J. Pasternak, Foto J. Pasternak. Quelle ARÚ Praha, FT000103256. 
veřejně známých osob či zaměstnanců KPR, časté jsou i zmínky o návštěvách ze zahraničí, včetně USA) se dozvídáme o občasném profesionálním sledování geologických poměrů v místech odkryvu či plánované letecké fotodokumentaci plochy výzkumu (v tomto konkrétním př́ípadě ovšem s dovětkem, že ,[letoun] nepřiletěl“). Iniciátora těchto aktivit ale neznáme.

Kromě důsledného vedení dokonalých deníkových záznamů o odkrývané terénní situaci svědčí o systematičnosti a klíčovém významu Pasternakova působení i bohatá fotodokumentace, kterou průběžně pořizoval po celou dobu svého působení na Hradě. Z výzkumu 3. nádvoří se dochovala početná série jeho autorských fotografíi s popisy (AMP, fotografická sbírka), a to právě včetně několika snímků s vyznačenými sídlištními horizonty.

Deníkové záznamy z ostatních Pasternakových pražských terénních výzkumů s výjimkou výzkumu románských domů mezi Kaprovou a Platnéřskou ulicí (ÚDU, H 9/6) se zatím nalézt nepodařilo a není vyloučeno, že se nedochovaly. Deník z výzkumu v místě budoucí nové pražské radnice není svou propracovaností se současnými záznamy (1926) z 3. nádvoří srovnatelný. Pokud jde o skici situací, obsahuje téměř výlučně pouze půdorysy odkrývaných konstrukcí. Podle zevrubného Pasternakova slovního popisu lze však rekonstruovat alespoň základní stratifikaci a mocnost jednotlivých popisovaných horizontů kulturního nadloží (obr. 18). O průběhu výzkumu J. Pasternak průběžně informoval R. Hlubinku (někdy i se stručným dovětkem týkajícím se výzkumu Pražského hradu). Z této zcela neoficiální korespondence (dochované na útržcích listů bloku apod.) také vyplývá, že podmínky výzkumu se od hradních významně lišily, a to přesto, že

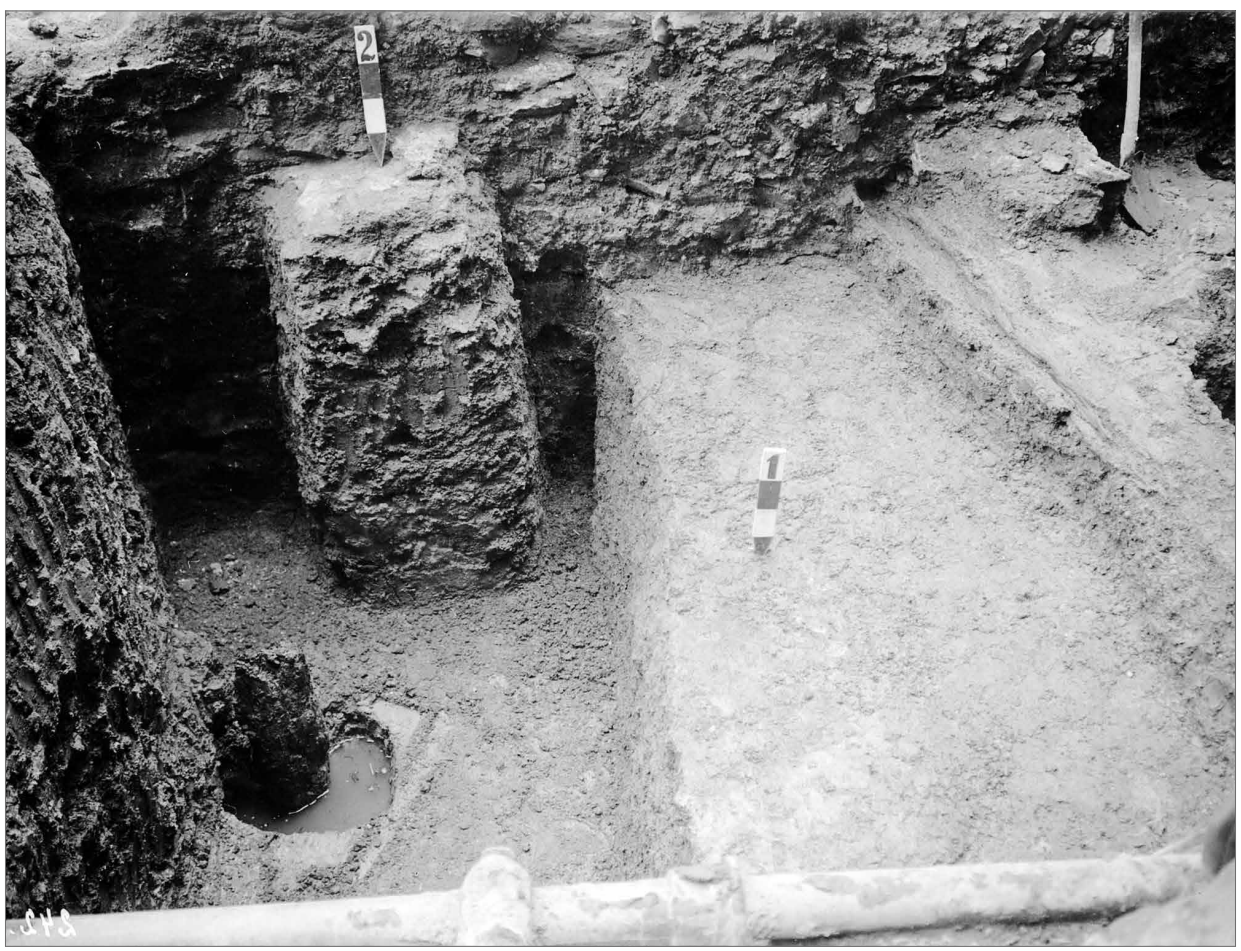

Obr. 17. Pražský hrad, 3. nádvoří. Rozebírání svrchní částí mladšího hradebního tělesa před vstupem do tehdejšího ministerstva zahraničí s odkrytými horizontálními i vertikálními dřevěnými prvky. Pohled od západu, foto J. Pasternak, 29. září 1926. Zdroj ARÚ Praha, pozůstalost I. Borkovského, FT000103242.

Abb. 17. Prager Burg, 3. Hof. Zerlegung des oberen Teils des jüngeren Burgmauerkörpers vor dem Eingang in das damalige Außenministerium mit freigelegten horizontalen und vertikalen Holzelementen. Blick aus Westen. Foto J. Pasternak, 29. September 1926. Quelle ARÚ Praha, Nachlass von I. Borkovský, FT000103242. 


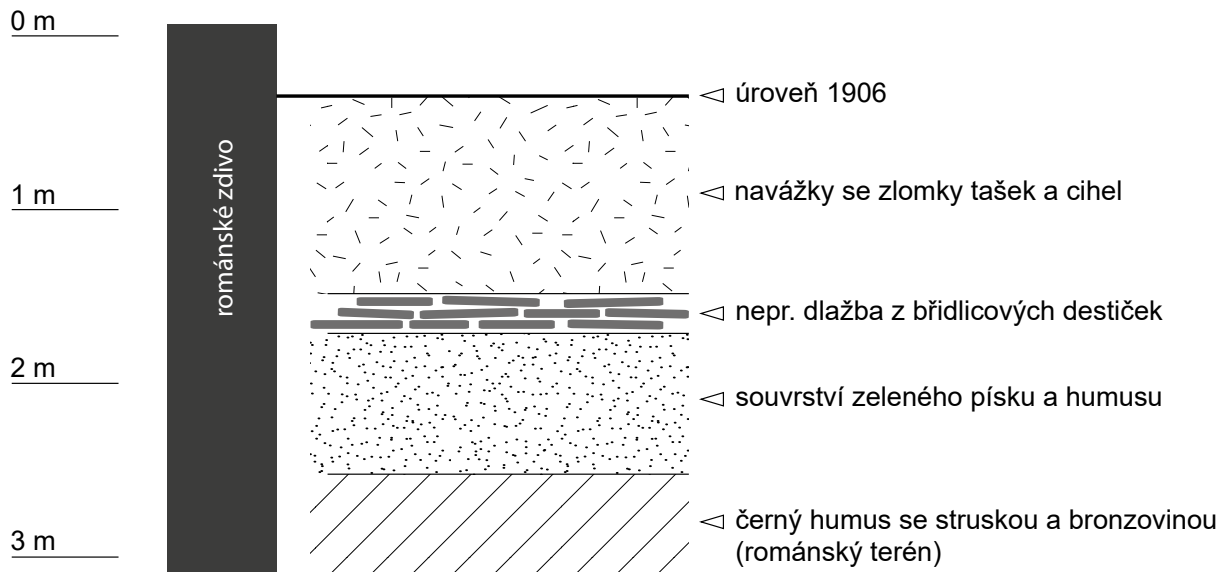

Obr. 18. Praha 1, Platnéřská - Kaprova. Rekonstrukce kulturního nadloží dle deníku výzkumu J. Pasternaka (1926). Grafické řešení I. Boháčová, $S$. Babušková.

Abb. 18. Prag 1, Straßen Platnéřská - Kaprova. Rekonstruktion des Kulturoberbodens laut Grabungstagebuch von J. Pasternak (1926). Graphische Darstellung I. Boháčová, S. Babušková.

význam odkrytých románských objektů byl mimořádný. Tlak ze strany prováděcí stavební firmy na minimalizaci rozsahu výzkumu a jeho maximální rychlost byl soustavný, a Pasternak proto opakovaně žádal Hlubinku o intervenci ve prospěch výzkumu.

Dochované archiválie ve svém souhrnu nasvědčují tomu, že krátké působení Jaroslava Pasternaka v počátcích archeologického výzkumu středověké Prahy bylo klíčovou kapitolou, v jejímž rámci byla nastavena základní kritéria jejího moderního výzkumu. Co J. Pasternaka v tomto ohledu ovlivnilo, není zřejmé. V každém případě ještě pro druhou polovinu 30 . let 20. století nenasvědčují archiválie př́iliš tomu, že by pro Pasternakovy souputníky byl výzkum po přirozených vrstvách a řešení otázek stratigrafie běžnou součástí výzkumných aktivit. I. Borkovský po převzetí dohledu nad výzkumem 3. nádvoří v deníkových zápiscích na způsob dokumentace a popisu terénního odkryvu J. Pasternaka jednoznačně navazuje, jeho preciznosti ale nedosahuje. ${ }^{5}$

To, že popsaná kapitola (nejen pražské) archeologie středověku a Pasternakův přínos pro rozvoj archeologického studia Prahy zůstaly dlouho opomíjeny a byly tak téměř zapomenuty, bylo nejspíše ovlivněno i skutečností, že se jeden z nejrozsáhlejších, nejkomplikovanějších a nejvýznamnějších výzkumů své doby z mnoha objektivních důvodů nedočkal řádného zpracování a vyhodnocení a početné archiválie, které jsou k němu dochovány v řadě institucí, nejsou dodnes v plné šíři zpř́ístupněny.

\footnotetext{
5 Za kvalitativní zlom a v podstatě pro české prostředí zcela inovativní počin ve vnímání kulturní stratigrafie a její náležité dokumentace, odpovídající i současným nárokům moderní archeologie, je dnes označován výzkum opevnění (opakovaně J. Klápště; zatím naposledy viz Štefan 2019,91 ) uskutečněný I. Borkovským až na sklonku 30. let (Borkovský 1941). Lze jen potvrdit, že žádný z předchozích výzkumů I. Borkovského dokumentací srovnatelné úrovně nedisponuje. Za inspirační zdroj považuje v tomto případě J. Klápště holandského archeologa A. E. van Giffena (1884-1973), jehož výzkumné metody používané při studiu pravěkých mohyl a způsob dokumentace jejich zvrstvení byly v Československu známé již od předválečných let. V jedné z připravovaných publikací Klápště připouští, že stejný badatel ovlivnil i J. Pasternaka.
} 


\section{Archeologický výzkum ,pražské půdy a v ní skrytých věcí“}

\subsection{Témata a metody}

Jedním z naléhavých úkolů, s nimiž se nově budované instituce památkové péče a základního výzkumu musely vyrovnat, bylo sledování rozsáhlých stavebních aktivit na území historického jádra Prahy s ohledem na možné narušení archeologických nálezů. V průběhu 20. let se pozornost Památkového sboru hl. města Prahy zaměřila obzvláště na území Starého Města pražského, které bylo po přijetí asanačního plánu v roce 1895 intenzivně zasaženo bouracími a následně stavebními pracemi především v oblasti Josefova, respektive severně linie vedoucí od Vltavy Platnéřskou ulicí přes Staroměstské náměstí do Dlouhé ulice. Asanační práce ovlivnily na dlouhou dobu vzhled jednotlivých částí historického centra. Intenzivní výstavba spojená se změnou urbanismu a vytyčením nových ulic v asanovaném území měla značný dopad na památkový fond, včetně archeologických terénů. Postupem doby se stavební aktivita rozšíríila na další katastrální území v centru Prahy, jakými byly Malá Strana, Hradčany a vybrané plochy na území Nového Města pražského.

Přes veškerou snahu o systematickou evidenci stavebních zásahů mohl být z důvodů finančních a zejména kapacitních ve srovnání s množstvím realizovaných staveb v centru města odborně sledován jen omezený počet cíleně vytipovaných historicky nejvýznamnějších stavbami ohrožených míst a objektů. Ačkoliv byla pozornost zaměřena hlavně na významné historické areály a prostranství, opomenuty nezůstávaly ani menší obytné domy a jejich soubory. V dnešním slova smyslu šlo o dohled při výkopech či jiných stavebních pracích nebo v prŕípadě zjištění pozitivních nálezů o operativní dokumentaci, tedy o dokumentaci průběžně pořizovanou při objevu a následném odkryvu zaniklých staveb. Zjištěné stavební konstrukce nebo archeologické nálezy byly většinou jednoduše popsány a vyfotografovány. $Z$ dnešního pohledu zcela elementární postup však v případě náhodných zjištění znamenal zachování zcela klíčových informací o povaze narušené archeologické situace. O popisy se postarali převážně profesionální odborníci nebo zainteresovaní komunální úředníci, zejména K. Guth a za úřední stranu hlavně R. Hlubinka. $Z$ archiválií je zřejmé, že i do výzkumu prostoru středověkého města byli zapojeni mladí adepti z řad absolventů pražské archeologie, především J. Pasternak a posléze - než získal trvalé uplatnění v StAÚ - I. Borkovský. Úloha I. Borkovského nabývala postupně na významu v závěru prvorepublikového období.

Mimo areály Pražského hradu a Vyšehradu v prostoru města obecně převažovala dokumentace již vykopaných ploch, i zde se ale v průběhu 20. let začal pozvolna prosazovat archeologický výzkum spojený se stavebními pracemi nebo je předcházející. Odborně vedený terénní odkryv historických terénů byl však realizován pouze u několika větších akcí, kde investorem stavebního záměru byl magistrát nebo stát (především velkoplošný odkryv na Loretánském náměstí, dále ve vnitrobloku Bartolomějské ul., výkopy protipožárních nádrží na Staroměstském, Malostranském i Hradčanském náměstí, výzkumy v areálu Anežského kláštera - soupis podchycených archeologických akcí nebo zjištění viz obr. 1; tab. 1). Rovněž z těchto výzkumů se zachovalo poměrně velké množství v řadě př́ípadů dosud detailněji nevyhodnocené fotografické dokumentace uložené v archivních a dalších institucích.

\subsection{Románská sakrální architektura}

Mezi první objekty, které se dostaly do hledáčku výzkumníků, náležely zaniklé nebo stávající sakrální stavby. Již v průběhu 20. let byly provedeny odkryvy v interiérech stávajících kostelů za účelem ověření podoby jejich stavebního předchůdce (kostel sv. Václava na Zderaze na Novém Městě - J. Pasternak, 1927-1928?, obr. 19; Sedláčková 1933; bazilika sv. Petra na Poříčí na Novém Městě - V. Birnbaum, 1928-1929, Frejková 1937, 1940), nebo v místech očekávaných nebo předpokládaných zaniklých staveb (kostel sv. Benedikta na Starém Městě - J. Böhm, 1927-1929, Ječný-Olmerová 1992). Rovněž u tématu evidence a dokumentace sakrálních staveb se setkáváme 


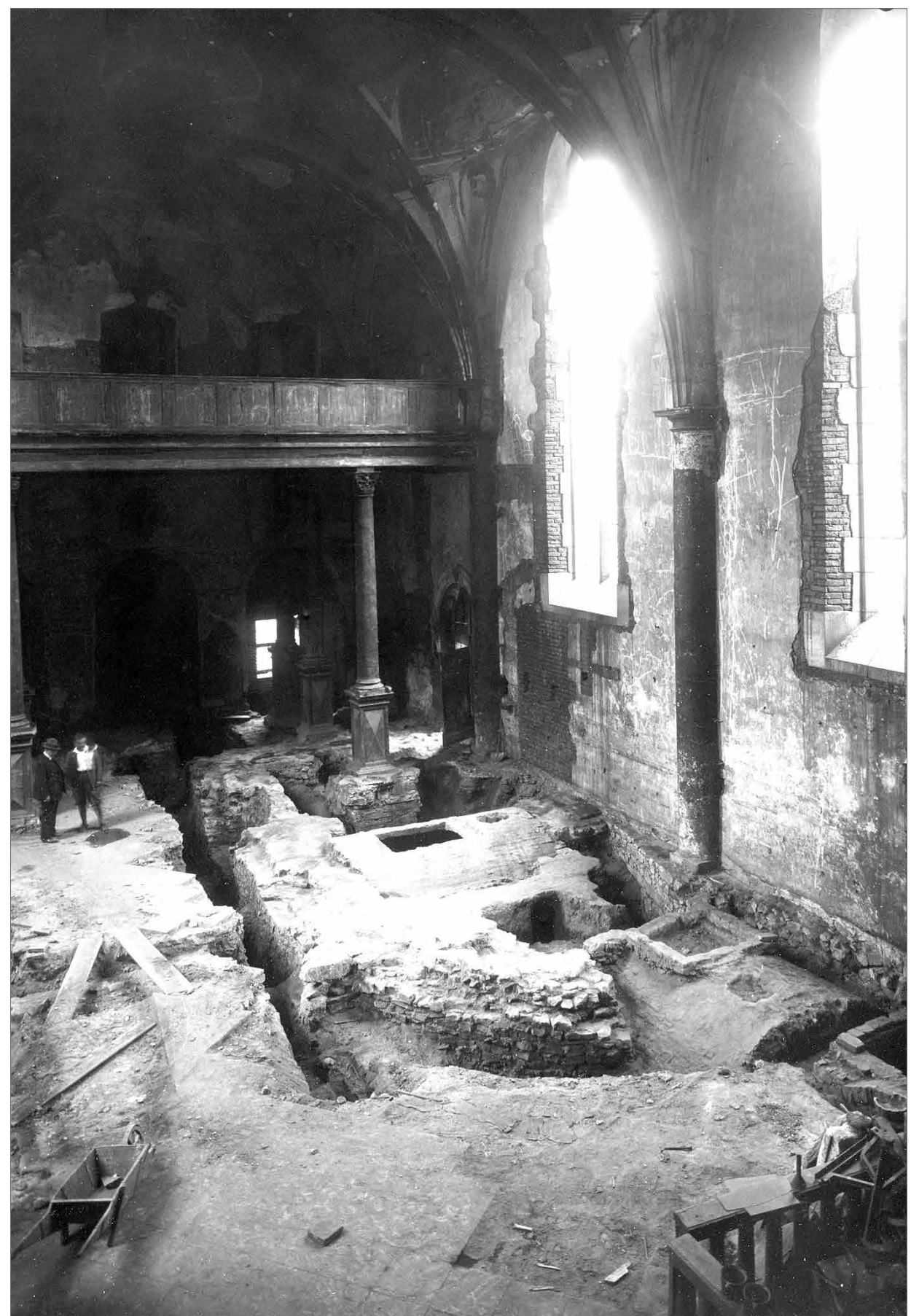

Obr. 19. Praha 2, kostel sv. Václava na Zderaze, 9. záŕí 1927. Pohled do interiéru kostela s odkrytými částmi jeho románského předchůdce v době výzkumu J. Pasternaka. Památkový sbor, A3601A. Zdroj ARÚ Praha, pozůstalost I. Borkovského.

Abb. 19. Prag 2, Kirche St. Wenzel von Zderaz, 9. September 1927. Blick ins Kircheninnere mit freigelegten Teilen ihrer romanischen Vorgängerin während der Grabung von J. Pasternak. Denkmalbeirat, A3601A. Quelle ARÚ Prag, Nachlass von I. Borkovský. 
se jménem R. Hlubinky a jeho osobním nasazením. Z hlediska cíleně vedeného archeologického bádání stojí za zmínku nález a následný odkryv pozůstatků zaniklého románského kostela sv. Jana Evangelisty na bojišti v roce 1929 (obr. 20). O existenci tohoto votivního kostela z konce 12. století se vědělo, dlouho ale nebyla známa jeho podoba. Teprve při stavbě Lékařského a Důstojnického domu (dnes čp. 486 a 490) na západní straně náměstí I. P. Pavlova, kdy stavební firma „ochotně hlásila nález zdiva v hloubce asi pưl metru“, byly „,za stálého dozoru“ a pod metodickým vedením R. Hlubinky odkryty fragmenty opukového zdiva této stavby (Hlubinka 1929; 1951). Díky Hlubinkovu angažmá byla tato část zaniklého kostela zdokumentována a popsána. Dochovány jsou krom stručného textu publikace rukopisné poznámky a náčrty a několik fotografí́ (Hlubinka 1929; ÚDU, H 7/2; ARÚ Praha). Po skončení akce však odhalené pozůstatky kostela musely ustoupit plánované novostavbě. Jednalo se o východní polovinu obdélného kostela s půlkruhovou apsidou včetně jižního vstupu. Západní část stavby s věží byla odkryta až o několik desetiletí později v letech 1982-1983 a je stále skryta pod současným povrchem na parcele čp. 465 (Olmerová 1987).

K nálezu pozůstatků zaniklých sakrálních staveb však docházelo i při běžné obnově inženýrských sítí. Příkladem může být odborným bádáním zapomenutá operativní dokumentace pozůstatků jižní apsidy románské tetrakonchy zbořeného kostela sv. Jana Křtitele, provedená R. Hlubinkou ve výkopu (50 cm širokém a $100 \mathrm{~cm}$ hlubokém) pro plynové potrubí v ulici Na Zábradlí 23. dubna 1940. Za zmínku stojí i skutečnost, že současně byl odebrán vzorek dnes již patrně nedochovaného maltového pojiva jako srovnávací materiál (ÚDU, fond $H$ 7/2). K vlastnímu odkryvu zbývajících částí této stavby došlo v suterénu domu čp. 205 až o více než šedesát let později v roce 2001 (Podliska 2002).

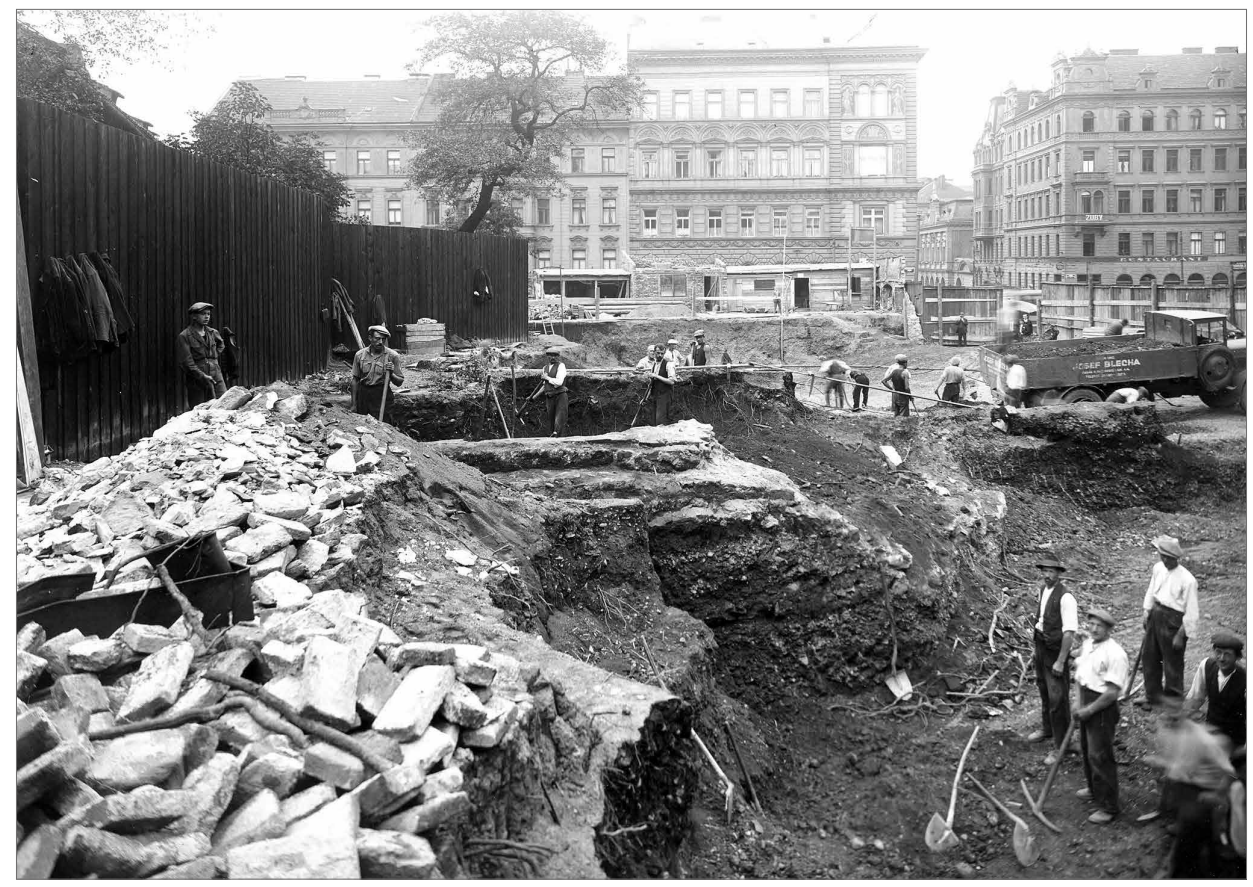

Obr. 20. Praha 2, Sokolská třída, 10. července 1929. „Vykopávky románského kostelíka sv. Jana na bojišti. Objeveno při vykopávkách půdy pro základy novostavby domu důstojnického a domu lékařuo. Památkový sbor, A5147A. Zdroj ARÚ Praha, pozůstalost I. Borkovského.

Abb. 20. Prag 2, Straße Sokolská tř́ída, 10. Juli 1929. „Ausgrabung der romanischen Kleinkirche St. Johannes am Schlachtfeld. Entdeckt bei der Aushebung des Bodens für die Fundamente des Neubaus eines Offiziershauses und eines Ärztehauses.“ Denkmalbeirat, A5147A. Quelle ARÚ Praha, Nachlass von I. Borkovský. 


\subsection{Výzkum městské zástavby a pozůstatků staroměstského opevnění}

Realizace archeologického výzkumu před zahájením stavby - tj. v dnešní terminologii výzkumu předstihového - byla $v$ průběhu 20. let zcela novým a do té doby nepraktikovaným činem městské správy. Opět i v tomto př́ípadě hybatelem a koordinátorem uvedených akcí byl Památkový sbor hl. města Prahy, z jehož popudu byly tyto výzkumy prováděny. $V$ historickém centru města se místem, kde byl umožněn předstihový výzkum, stala plocha staveniště pro novostavbu magistrátní budovy tzv. Nové radnice na nároží ulic Kaprovy a Platnéřské. Zde byla v roce 1926 v místech již dřive asanované části staroměstského bloku domů zahájena terénní skrývka. Z pověření magistrátního rady R. Hlubinky a ve spolupráci s ním archeologický dohled nad výkopy, které postupně odkrývaly pozůstatky starší zástavby, zajištoval výše zmíněný J. Pasternak. Samotné výkopové práce probíhaly v součinnosti s dodavatelem stavebních prací. Při nich se na ploše stavby podařilo odkrýt dvojici románských staveb kvádříkové konstrukce, které náležely $\mathrm{k}$ zbořenému objektu čp. 16, tzv. Andělské koleji, a k domu čp. 31 původně situovanému do Kaprovy ulice (obr. 5-6). Jediné dostupné informace, ze kterých si lze udělat rámcovou představu o průběhu akce, obsahuje dochovaný deník výzkumu se stručnými písemnými záznamy s popisy některých situací (viz rekonstrukce na obr. 18), volné zápisky J. Pasternaka a korespondence mezi ním a R. Hlubinkou (ÚDU, H 7/2). Fotografická dokumentace je uložena ve fondech ARÚ Praha a Archivu hl. města Prahy. Z uvedených podkladů je zřejmé, že hlavním cílem snažení byl odkryv stavebních konstrukcí, přičemž pozornost byla věnována obzvláště pozůstatkům románských staveb. Uvedenému odpovídal i způsob terénních prací, během nichž byly zdi odhalovány až na úroveň jejich základu. Deníkové záznamy obsahují vedle provozních údajů o postupu prací hlavně popisy částí konstrukcí, jejich rozměry a stavební formu. Měřičské údaje jsou doplněny situačními skicami jednotlivých zdí a plánky celkové situace místa. Z komentářů J. Pasternaka je zřejmé, že výzkum byl soustavně komplikován především termíny a harmonogramem vlastní stavby. R. Hlubinka se jako reprezentant Památkového sboru několikráte a $\mathrm{s}$ odborně fundovaným zdůvodněním významu odkrývaného souboru raně středověkých památek zasazoval na půdě magistrátu nejen o to, aby výzkum proběhl za podmínek adekvátních důležitosti mimořádného nálezu, ale i o jeho alespoň dílčí uchování. Jak uvádí Pasternak ve svých písemných intervencích adresovaných Hlubinkovi: ,„...) handlovali jsme o každý metr jako Židi [rozuměj s vedením stavby], konečně dostal jsem (totiž dostali jsme) štastné povolení na bádáni podle Vašeho práni [rozuměj Hlubinkova], až na několik drobnůstek, které si později podle potřeby dovedeme také vyhandlovati“ (ÚDU, H 7/2). Samotné výzkumné práce probíhaly s větší letní přestávkou necelé tř̌i měsíce (dvě výzkumné kampaně: 20. 4. - 2. 6. a 25. 8. - 20.9. 1926). Zajímavostí je, že zmíněné přerušení prací na stavbě bylo způsobeno pořádáním Všesokolského sletu jakožto celonárodně sledované akce odehrávající se v Praze.

Výsledkem celkového snažení i osobního nasazení aktérů jedné z prvních záchranných archeologických akcí v historickém centru Prahy provázeného kvalifikovaným zdůvodněním historického významu dochovaného raně středověkého komplexu objektů byla záchrana souboru unikátních kvádříkových staveb. Památková hodnota nálezu zapříčinila změnu projektu stavby a vedla $\mathrm{k}$ jejich zachování na původním místě v suterénu novostavby se záměrem je v budoucnu náležitě prezentovat. Tento úmysl se od doby nálezu i přes opakované pokusy nepodařilo prosadit dodnes.

Intenzivní stavební činnost $\mathrm{v}$ této době, spojená $\mathrm{s}$ výstavbou řady veřejných a komerčních budov, vedla k velkoplošným odkryvům uprostřed stávající nebo asanované historické zástavby. Tato skutečnost měla mimo jiné zcela zásadní dopad na poznání průběhu linie zaniklého středověkého opevnění Starého Města pražského (Uličný 2006). Rozsahem největší akce proběhla v roce 1928 v souvislosti se stavbou nového paláce Ministerstva průmyslu, obchodu a živností (čp. 1039 v sousedství Anežského kláštera; Uličný 2006, 77-79). Na staveništi o velikosti více než 0,5 ha byly odhaleny pozůstatky systému opevnění s hlavní hradbou, parkánem, parkánovou zdí a příkopem, původně náležející nejvýchodnější části staroměstské fortifikace probíhající dále 
podle břehu. V průběhu výkopových prací realizovaných stavbou byla v průběhu dubna a května prováděna fotografická a místy i kresebná dokumentace klíčových nálezových situací pod dohledem R. Hlubinky. Většina dochované dokumentace je přímo Hlubinkou parafována. Důraz je u ní kladen na podchycení terénní situace se zřetelem na základní stratigrafické komponenty uloženin a konstrukcí.

Ve stejném roce se odehrávala rozsáhlá stavební aktivita na rozhraní náměstí Republiky a Revoluční ulice v místech, kde dříve stával kostel sv. Norberta (původně kostel sv. Benedikta;

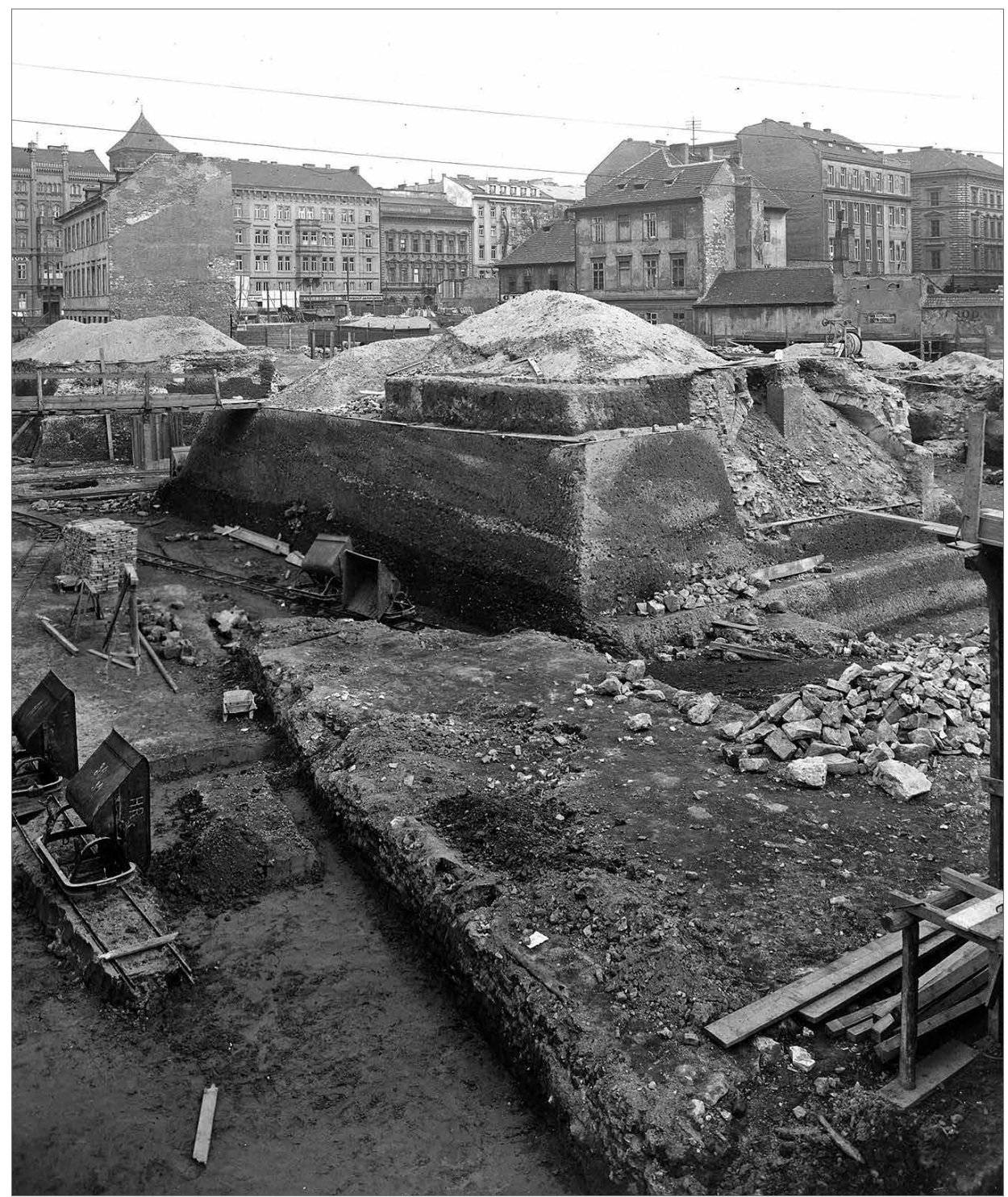

Obr. 21. Praha 1, Na Františku. Dokumentace staroměstského opevnění na staveništi budovy tehdejšího ministerstva průmyslu, obchodu a živností, 17. 5. 1928. Památkový sbor, A4186B. Zdroj ARÚ Praha, pozůstalost I. Borkovského.

Abb. 21. Prag 1, Na Františku. Dokumentation der Altstädter Befestigung an der Baustelle des damaligen Gebäudes des Ministeriums für Industrie, Handel und Gewerbe, 17. 5. 1928. Denkmalbeirat, A4186B. Quelle ARÚ Prag, Nachlass von I. Borkovský. 
foto viz AMP, fotografická sbírka ${ }^{6} \mathrm{~s}$ asanovanými objekty bývalého premonstrátského semináře Norbertina (Uličný 2006, 79-82). Záměr výstavby nové komerční budovy paláce Kotva čp. 655 byl spojen s rozsáhlými zemními zásahy v místech původně probíhajícího hradebního pásu. $Z$ dochované dokumentace je zřejmé, že výkop stavební jámy zastihl vedle hlavní hradební zdi i část parkánu a vyzdění vnitřní strany př́íkopu. Fotografická dokumentace odkryvů v okolí ulic Na Františku (obr. 21-22), Hradební a Revoluční pochází z dubna 1928 a je v tomto případě provázena i poměrně detailními popisy odkrývaných situací (AMP, Fotografická sbírka).

Od 30. let do výčtu míst s odhalenými a částečně dokumentací podchycenými nálezy pozůstatků staroměstského opevnění přibyly i lokality Na Příkopech (čp. 988), na rohu Perlové a 28. ř́jjna čp. 371 a především v místech staveniště nové budovy policejního ředitelství v Bartolomějské ulici čp. 310 (Uličný 2006, 77 a dále). Opět i v těchto prŕípadech je zřejmý zásadní podíl R. Hlubinky jako dohlížitele nad postupem prací a neúnavného dokumentátora klíčových nálezových situací, $v$ těchto prípadech tematicky svázaných se staroměstským opevněním. Celkem tak $\mathrm{z}$ dochované Hlubinkovy dokumentace můžeme čerpat informace $\mathrm{k}$ archeologickým poznatkům získaným při sledování šesti stavebních projektů, při kterých byly odhaleny nejen pozůstatky hradeb Starého Města, ale i další archeologické nálezy spojené s osídlením této části města.?

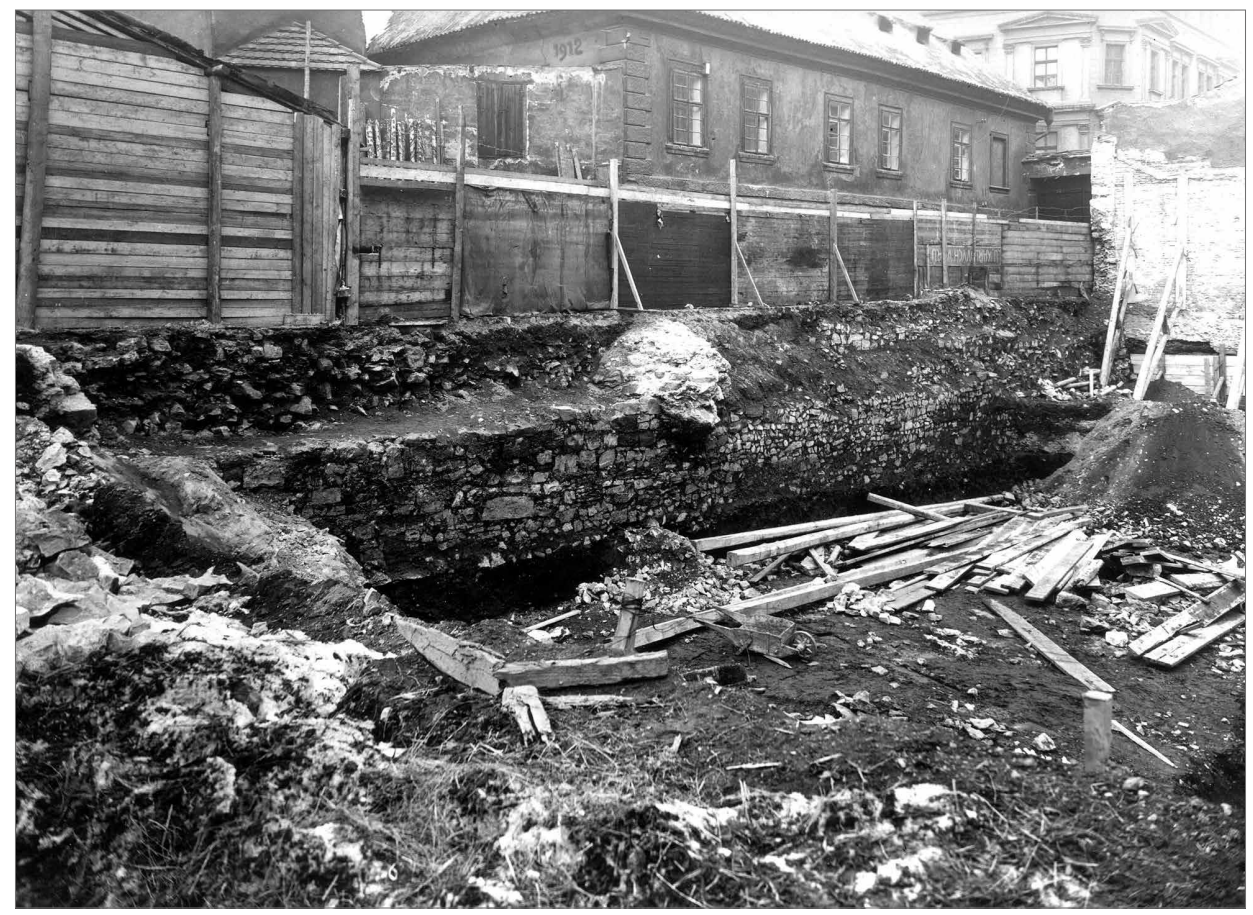

Obr. 22. Praha 1, Staré Město, Revoluční. Pohled na zbytek hradební zdi podél čp. 689 od severozápadu, 17. 3. 1928. Památkový sbor, A4032B. Zdroj ARÚ Praha, pozůstalost I. Borkovského.

Abb. 22. Prag 1, Altstadt, Straße Revoluční. Blick auf den Rest der Burgmauer entlang Konskriptionsnr. 689 aus Nordwesten, 17. 3. 1928. Denkmalbeirat, A4032B. Quelle ARÚ Prag, Nachlass von I. Borkovský.

6 Několik snímků nově zpř́ístupněno online v digitálním katalogu. Dostupné z: http://katalog.ahmp.cz/pragapublica/permalink?xid=F858A4E7161411E390486C626D41E503\&scan=1\#scan1, cit. 4. 4. 2020.

7 Část Hlubinkovy pozůstalosti vyčleněná z pozůstalosti Z. Wirtha zůstává aktuálně v neuspořádaných částech sbírky plánové dokumentace a sbírky historické fotografie, ÚDU AV ČR, odd. dokumentace (původně jako W-A-150/1 a W-A-151/5). Některé fotografie jsou již ale součástí digitálního katalogu. 
Archiválie fondu Archivu hl. města Prahy pak dokládají, že o nálezech a prováděném způsobu jejich dokumentace bylo pravidelně referováno na schůzích Památkového sboru (AMP, Magistrát hl. města Prahy, fond Památkový sbor, kart. 15, inv. č. 22).

\subsection{Badatelské aktivity v zázemí Prahy}

V průběhu předválečného období se zájem Památkového sboru hl. města Prahy nesoustředil pouze na historické centrum Prahy, ale v odůvodněném případě iniciovali jeho členové archeologické výzkumy i za jejími hranicemi. Př́kladem uvedených aktivit byly práce na obnově a výzkumu pozůstatků Nového hradu u Kunratic, gotické stavby krále Václava IV. z počátku 15. století (Podliska-Semerád 2015). Podnětem k zahájení výzkumu této mimopražské památky bylo pro vedení Prahy úspěšné završení snahy Památkového sboru získat pozemky s hradem do vlastnictví města, k čemuž došlo definitivně v průběhu roku 1928.

Hlavním hybatelem zájmu o tuto lokalitu a její výzkum byl historik a památkář Cyril Merhout, $\mathrm{v}$ té době zaměstnanec MŠANO. Byl to právě on, kdo se hradem dlouhodobě odborně zabýval a důrazně prosazoval ideu odkryvu hradní stavby, která po násilném zániku v roce 1421 a částečné demolici jejích pozůstatků někdejšími vlastníky, k níž došlo v roce 1881, zůstala zarostlá a z velké části zasypána příkrovem sutí a navážek. Společným úsilím a soustředěním finančních prostředků byl výzkum zahájen cíleným geodetickým zaměřením jak celé lokality včetně obléhacího tábora v předpolí v měřítku $1: 500$, tak samotných zbytků hradu před zahájením vykopávek a po nich v měřítku 1 : 100. Plány, které zhotovil Ing. Gustav Varvažovský, zůstaly zachovány ve fondu Archivu hl. m. Prahy (AMP, Sbírka map a plánů, neuspořádaná část, bez sign.). Obdobně byla provedena i fotodokumentace stálým spolupracovníkem sboru A. Alexandrem a patrně i dalšími aktéry celé akce (dnes rozptýleno v řadě kopií ve fondech AHMP, ARÚ Praha a NPÚ bez uvedení autorství). Vlastní výkopové práce byly zahájeny až na sklonku roku 1928 a trvaly pouhých 14 dnů. Stálý dozor nad výkopovými pracemi byl svěřen Jiřímu Müllerovi, který byl na tuto práci vyžádán u Komise pro výzkum Vyšehradu, kde v té době působil. První etapa byla přípravnou fází rozsáhlejšího odkryvu, který byl zahájen po důkladnější materiální přípravě na počátku května 1929. Ve dvojici deníků výzkumu zachovaných ve fondu Národního muzea (NM, Praha - Kunratice, odd. starších českých dějin historického muzea) máme možnost sledovat den po dni jednotlivé kroky spojené s organizací práce, s postupem vykopávek a jednotlivými nálezy. Krátce po zahájení druhé sezony byl J. Müller vystř́ián tehdy začínající absolventkou archeologie Libuší Jansovou (obr. 23). Po celou dobu vykopávek je z dochovaných zpráv zřejmý velký zájem, kterou o akci projevovaly významné postavy tehdejší památkové péče a archeologického bádání. Mezi pravidelnými účastníky prohlídek výzkumu a schůzek meziinstitucionálních komisí se vedle C. Merhouta, R. Hlubinky a dalších vysoce postavených úředníků MHMP a MŠANO objevují i profesionální archeologové K. Guth, A. Stocký nebo J. Schránil. O průběhu a organizaci výzkumných prací nás dnes informuje konvolut úředních písemností Památkového sboru, Magistrátu hl. m. Prahy a Ministerstva školství a národní osvěty, uložených v archivních fondech několika institucí (Národní archiv, fond státní památkové správy; Ministerstvo školství, fond Ministerstva školství; Archiv hlavního města Prahy, MHMP, fond Památkový sbor hlavního města Prahy; Ústav dějin umění, fond Rudolfa Hlubinky). $Z$ metodického hlediska je zřejmá snaha o odkrytí jednotlivých konstrukcí hradní stavby, kde jádrem byl velký hradní palác a následně stavby s ním spojené (čelní břitová věž a 2. hradní brána). Vlastní dokumentace prováděná čerstvými absolventy oboru J. Müllerem a L. Jansovou je až na výjimky jednoduchá, tvořená skicami nálezových situací, především zdí, a jejich popisy, zcela v menšině jsou vertikální stratigrafie s popisem uloženin (obr. 24). $\mathrm{Z}$ deníku můžeme rekonstruovat též charakter nálezů, mezi nimiž převažují popisy architektonických článků (opět doplněné kresebnou skicou), př́ípadně jsou zmíněny nálezy drobných předmětů materiální kultury ze zásypu hradních objektů. Celý soubor nebyl nikdy vyhodnocen a až na jedinou výjimku (krbová římsa uložená v lapidáriu NM) je v současné době nezvěstný. 


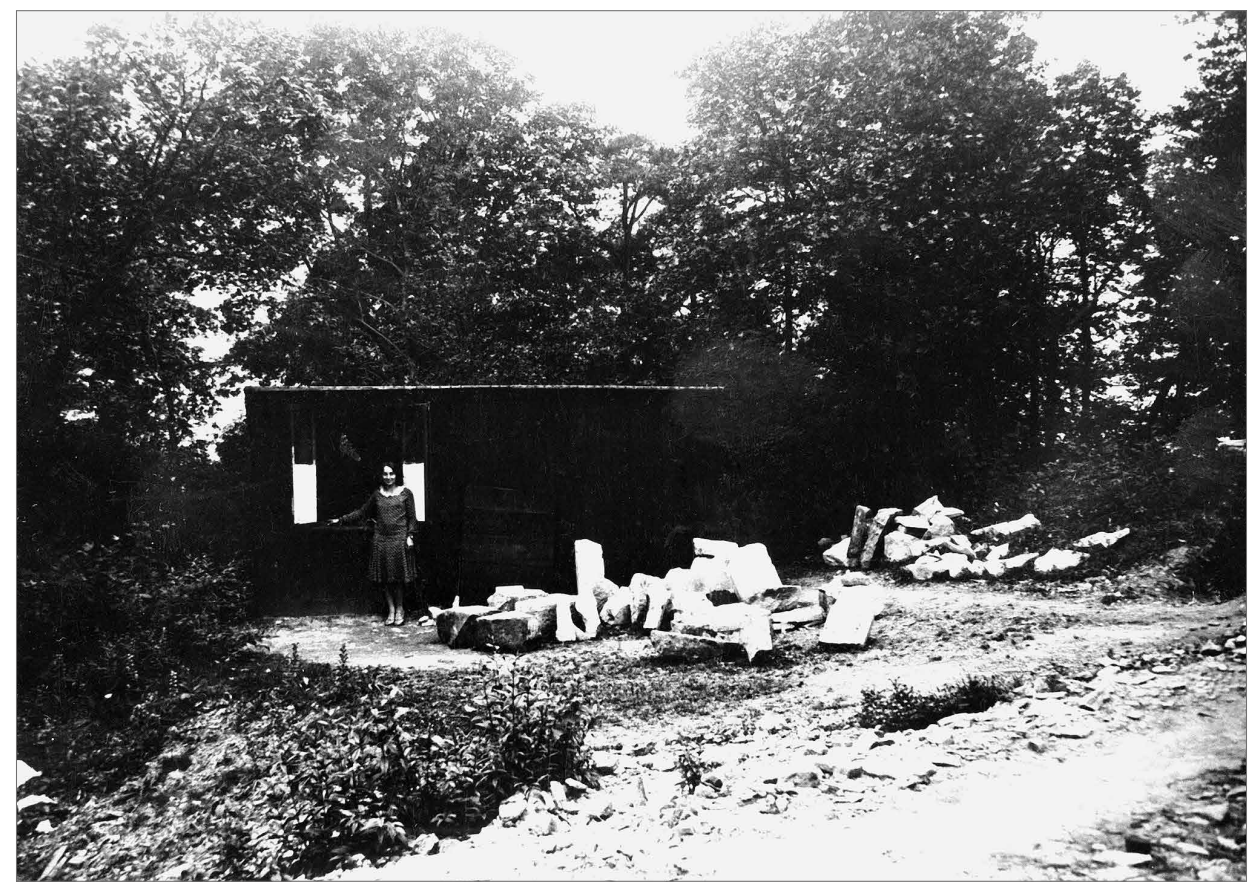

Obr. 23. Praha - Kunratice, Nový hrad. Vedoucí druhé sezony výzkumu Libuše Jansová před dřevenou boudou s architektonickými nálezy z hradu v létě 1929(?), autor fotografie neurčen. Zdroj ARÚ Praha, FT000081744A.

Abb. 23. Prag - Kunratice, Wenzelsburg. Die Leiterin der zweiten Grabungssaison Libuše Jansová vor einer Holzhütte mit architektonischen Funden von der Burg im Sommer 1929(?), Autor der Fotografie unbestimmt. Quelle ARÚ Prag, FT000081744A.

Důležitou stránkou výzkumu bylo finanční krytí nákladů, o které se podělily Památkový sbor a MŠANO formou sdružených městských a státních subvencí. Manuální pracovníci výzkumu se rekrutovali z řad nezaměstnaných obyvatel. Ze záznamů je zřejmý velký zájem o tyto práce. Již v průběhu druhé sezony výzkumu se v úředních hlášeních a zprávách z jednání komise objevují četnější poznámky ke kompetenčním sporům mezi Památkovým sborem, jím pověřenými odborníky a C. Merhoutem jako zástupcem MŠANO (ÚDU, H 10/3). Kombinace všech těchto faktorů s nastupující hospodářskou krizí nepochybně vedla k ukončení výkopových prací na hradě a stavebnímu a statickému zajištění některých vykopaných zdiv.

Během dvou neúplných sezon se podařilo odkrýt ústřední stavby hradu v podobě rozměrného sklepa hlavní palácové budovy s čelní věží a pozůstatky druhé hradní brány s př́ikopem (obr. 25). Vybrané části hradních konstrukcí nechala pražská obec již v průběhu samotné akce a následně na počátku 30. let 20. století provizorně zajistit a projekt výzkumu hradu tím pak byl na více než osmdesát let zcela uzavřen (Podliska-Semerád 2015). Z hlediska dnešních nároků na akce podobné povahy lze odkryv a následné zajištění reliktů hradní architektury hodnotit jako metodicky a organizačně nepřipravené. Svou roli zde sehrály osobní ambice jednotlivých aktérů a absence propracované metodiky výzkumu a konzervace hradních staveb, k nimž se obor archeologie dopracoval až v průběhu doby současné (Sokol-Durdík-Štulc 1998). Jako naprosté selhání zde můžeme hodnotit přistup někdejšího vlastníka odhalené zříceniny, který i s přihlédnutím $\mathrm{k}$ dalším historickým událostem měl velký podíl na následné devalvaci části odhalených konstrukcí hradu. Té nezabránily ani dobře míněné, ale ve svých výsledcích - kvůli spíše osobním než odborným sporům - nakonec problematické snahy odborné veřejnosti. 


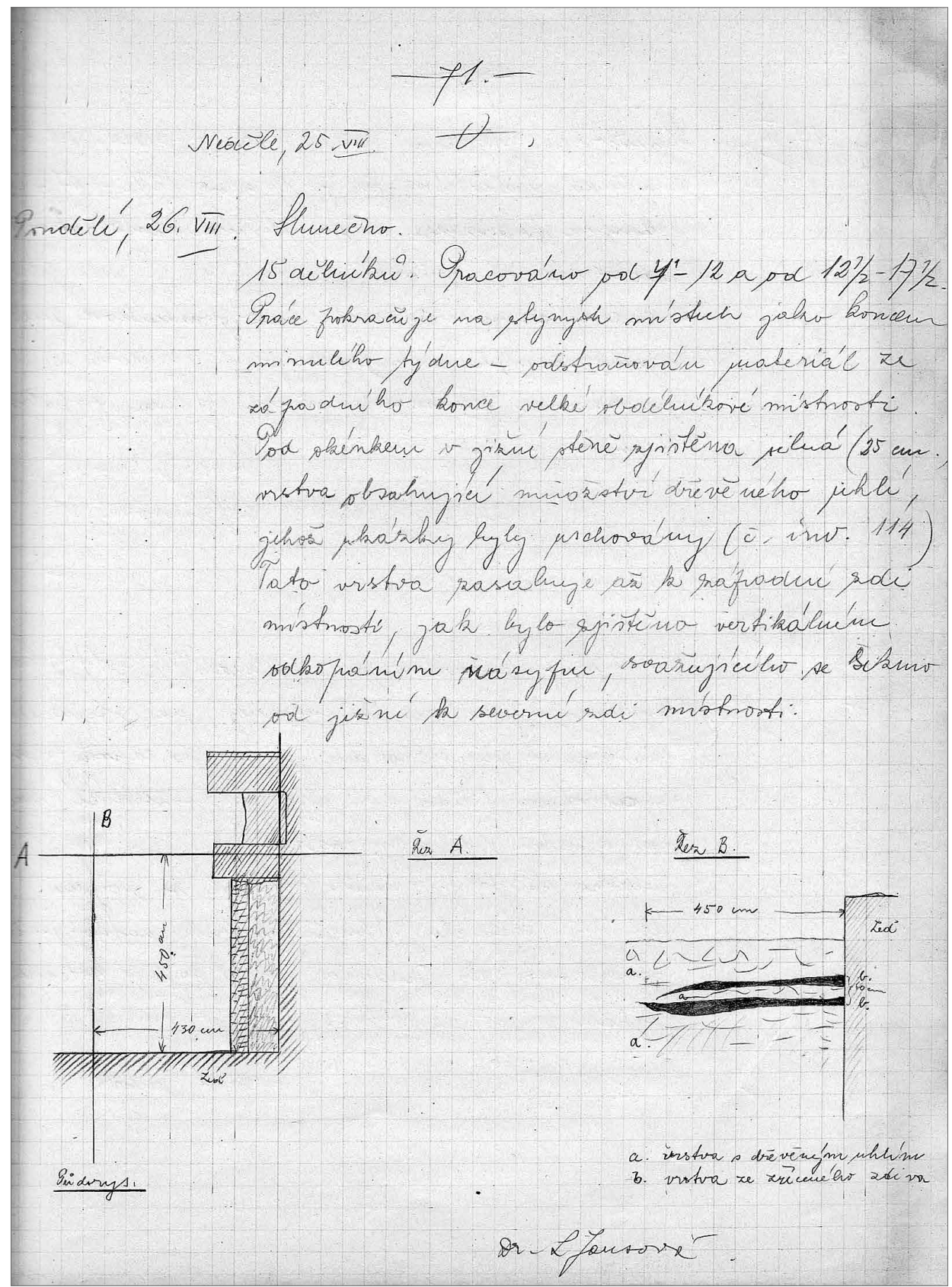

Obr. 24. Praha - Kunratice, Nový hrad. Stránka z deníku výzkumu L. Jansové ze dne 26. 8. 1929 s popisem průběhu prací a kresebnou dokumentací půdorysu části sklepení hradního paláce a přilehající terénní situace. Zdroj NM, odd. starších českých dějin historického muzea, fond Praha - Kunratice, bez sign. Reprodukce F. Flek.

Abb. 24. Praha - Kunratice, Wenzelsburg. Seite aus dem Grabungstagebuch von L. Jansová vom 26. 8. 1929 mit Beschreibung des Arbeitsverlauf und Zeichendokumentation des Grundrisses eines Teils des Kellers des Burgpalas und der angrenzenden Geländesituation. Quelle NM, Abt. Ältere böhmische Geschichte des historischen Museums, Bestand Prag - Kunratice, unsigniert. Reproduktion F. Flek. 


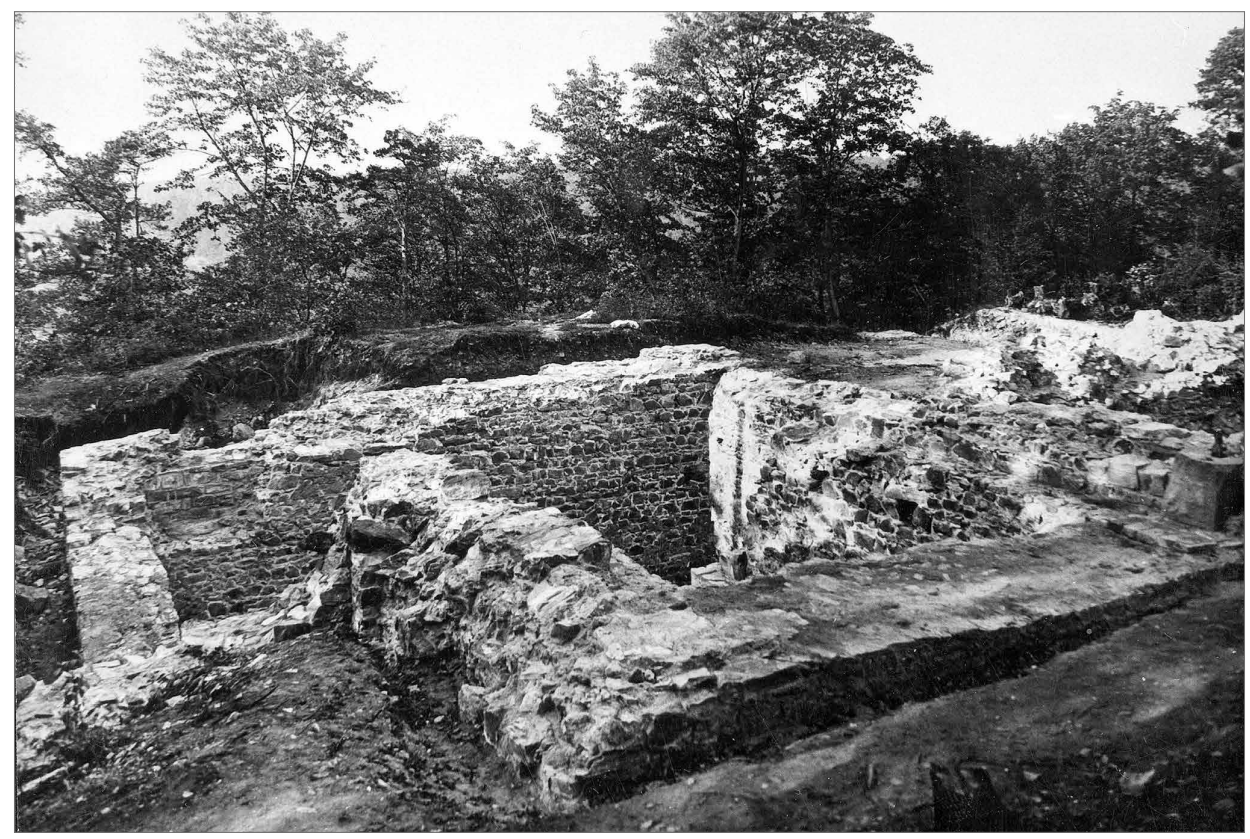

Obr. 25. Praha - Kunratice, Nový hrad. Pozůstatky druhé hradní brány odhalené výzkumem v roce 1929, autor fotografie neurčen. Zdroj ARÚ Praha, FT000081748A.

Abb. 25. Prag - Kunratice, Wenzelsburg. Bei der Grabung von 1929 freigelegte Überreste des zweiten Burgtors, Autor der Fotografie unbestimmt. Quelle ARÚ Prag, FT000081748A.

\section{Závěr}

Přes veškeré limity dané nejprve zejména naprostým nedostatkem odborných kapacit a posléze zhoršující se hospodářskou i společenskou situací, která vyvrcholila propuknutím válečného konfliktu s jeho všemi ničivými důsledky, je dnes možné díky propracované koncepci výzkumu archeologických památek a jejich ochrany na práci našich předchůdců v mnohých ohledech navázat. Obdiv vyvolává osobní nasazení, zodpovědný a až na naprosté výjimky i kolegiální př́stup a důsledná meziinstitucionální spolupráce, s nimiž jeho tehdejší účastníci usilovali v rovině teoretické i praktické o vytvoření funkčního systému ochrany kulturního dědictví, jeho výzkumu a dokumentace. Archeologický fond včetně několika areálů s památkami dochovanými in situ (zvláště Boháčová 2016; Boháčová-Nechvátal 2014) a archivní materiály z výzkumů meziválečného období, které zůstaly zachovány především ve fondu AMP, ale také v řadě dalších institucí, jsou pro současné studium vzniku a vývoje Prahy často - jak jsme se pokusili na mnohých př́ikladech v tomto textu ukázat - klíčové, a tedy nepostradatelné.

\section{Prameny a literatura}

BEČKOVÁ, K., 1993: ASANACE - zatracovaný i obdivovaný projekt obce Pražské. Př́íspěvek k dějinám pražské asanace, Pražská asanace. K 100. výročí vydání asanačního zákona pro Prahu, Acta Musei Pragensis $93,35-55$.

BOHÁČOVÁ, I., 2001: Pražský hrad a jeho nejstarší fortifikační systémy - Die Prager Burg und ihre ältesten Befestigungssysteme. In: Pražský hrad a Malá Strana. Mediaevalia archaeologica 3 (Ježek, M.-Klápště, J., edd.), 179-301. Praha. 
- 2015: Prezentace archeologických památek v Čechách. Archeologické areály in situ - př́klady z Pražského hradu a Vyšehradu - Die Präsentation archäologischer Denkmäler in Tschechien. Archäologische Areale in situ am Beispiel der Prager Burg und des Vyšehrads (Prager Hochburg), AH 40, 331-351.

- 2019: Archeologie v Praze v kontextu vzniku Československé republiky, ZPP, 279-291.

BOHÁČOVÁ, I.-PODLISKA, J., 2020: Archeologie v Praze po vzniku ČSR. Počátky a organizace moderního výzkumu města. In: Dejiny archeológie. Archeológia v Československu v rokoch 1918-1948 (Neumann, M.-Mellnerová Šuteková, J., edd.), 315-355. Bratislava. Dostupné z: https://www.academia.edu/44098617/DEJINY_ARCHEOL\%C3\%93GIE_ARCHEOL\%C3\%93GIA_V_\%C4\%8CESKOSLOVENSKU_V_ROKOCH_1918_1948.

BOHÁČOVÁ, I.-NECHVÁTAL, B., 2014: Historie a současná obnova archeologického areálu s bazilikou sv. Vavřince v prostoru NKP Vyšehrad, ZPP 74, č. 1, 3-11.

BORKOVSKÝ, I., 1941: Soběslavská hradba v Rožmberském paláci na Pražském hradě, ZPP 8, č. 5, 113-123.

- 1943: Popis stratigrafie ve výkopu protipožární vodní nádrže na Malostranském náměstí v Praze 1, ulož. ARÚ Praha, čj. 275/86.

ČAREK, J., 1947: Praha románská. Praha.

GUTH, K., 1934: Praha, Budeč, Boleslav. Praha.

FREJKOVÁ, O., 1937: Kostel sv. Petra na Pořičí v Praze, Ročenka Kruhu pro pěstování dějin umění za rok 1936, 39-56.

- 1940: Kostel sv. Petra na Poříčí v Praze, Poklady národního umění 22, 39-56.

HLAVA, M.-KOSTKA, M., 2014: Archeologické výzkumy Muzea hlavního města Prahy a jejich proměny, Archaeologica Pragensia 22, 235-260.

HLUBINKA, R., 1929: Románský kostel sv. Jana na Bojišti, Za starou Prahu. Věstník pro ochranu památek 13, 34.

- 1931: Úmrtní dům Tychona Brahe, Zprávy památkového sboru hlavního města Prahy, 131-147.

- 1947: Románské domy na Starém Městě pražském, ZPP 7, č. 2-3, 25-46.

- 1951: Zprávy o některých románských nálezech v Praze, ČSPS 59, 30.

JEČNÝ, H.-OLMEROVÁ, H., 1992: Historie a proměny jednoho z bloků v hradbách Starého Města pražského, Staletá Praha 22, 21-70.

OLMEROVÁ, H., 1987: Výzkum votivního kostela sv. Jana na Bojišti, Staletá Praha 17, 71-82.

PŘIKRYLOVÁ, M., 2017: Vznik „Velké Prahy“ a snahy o systematickou fotografickou dokumentaci města ve 20.-30. letech 20. století - Die Entstehung „Groß-Prags“ und die Bemühungen um eine systematische fotografische Dokumentation der Stadt in den Zwanziger- und Dreißigerjahrendes 20. Jahrhunderts, Documenta Pragensia 36, 569-597.

PODLISKA, J., 2002: Nové poznatky o kostele sv. Jana Křtitele Na Zábradlí na Starém Městě pražském - Neue Erkenntnisse von der Kirche des hl. Johannes d. T. am Geländer in der Prager Altstadt, PRP 9, č. 1, Praha, 83-100.

PODLISKA, J.-SEMERÁD, M., 2015: Nový Hrad u Kunratic. Výzkum a obnova zanikající hradní stavby - Die Wenzelsburg bei Kundratitz (Nový Hrad u Kunratic), in Prag. Grabung und Wiederaufbau des zerfallenden Burgbaus, AH 40, 369-393.

SEDLÁČKOVÁ, E., 1933: Kostel sv. Václava na Zderaze v Praze, Ročenka Kruhu pro pěstování dějin umění za rok 1932, 47-62.

SOKOL, J.-DURDÍK, T.-ŠTULC, J., 1998: Ochrana, údržba a stavební úpravy zřícenin hradů. Odborné metodické publikace 17. Př́loha ZPP 58. Praha.

ŠTEFAN, I., 2019: Č́́ je ta krajina? Rozhovory s Janem Klápště o středověku i našem světě. Praha.

UHLÍKOVÁ, K., 2010: Zdeněk Wirth, první dvě životní etapy (1878-1939) - Zdeněk Wirth, the first two periods of life (1878-1939). Praha.

ULIČNÝ, P., 2006: Staroměstské opevnění v Praze v dokumentaci Rudolfa Hlubinky - Die Befestigung der Prager Altstadt in der Dokumentation von Rudolf Hlubinka, PRP 13, č. 1, 76-88.

\section{Zkratky / Abkürzungen}

ADB

AMP archeologické dokumentační body / archäologische Dokumentationspunkte

Archiv hl. města Prahy / Archiv der Hauptstadt Prag 


$\begin{array}{ll}\text { APH } & \text { Archiv Pražského hradu / Archiv der Prager Burg } \\ \text { KPR } & \text { Kancelář prezidenta republiky / Kanzlei des Präsidenten der Republik } \\ \text { MHMP } & \text { Magistrát hl. města Prahy / Magistrat der Hauptstadt Prag } \\ \text { MMP } & \text { Muzeum hl. města Prahy / Museum der Hauptstadt Prag } \\ \text { MÚA } & \text { Masarykův ústav a Archiv Akademie věd České republiky / Masaryk-Institut und } \\ & \text { Archiv der Akademie der Wissenschaften der Tschechischen Republik } \\ \text { NA } & \text { Národní archiv / Nationalarchiv } \\ \text { NM } & \text { Národní muzeum / Nationalmuseum } \\ \text { PPR } & \text { Pražská památková rezervace / Prager Denkmalreservat } \\ \text { StAÚ } & \text { Státní archeologický ústav / Staatliches archäologisches Institut } \\ \text { SPÚ } & \text { Státní památkový úřad / Staatliches Denkmalamt } \\ \text { ÚDU } & \text { Ústav dějin umění / Institut für Kunstgeschichte }\end{array}$

\section{Zusammenfassung}

\section{Die Archäologie des Mittelalters in Prag zwischen den beiden Weltkriegen - vergessene Kapitel der Geschichte des Fachs}

Der Prager Archäologie des Mittelalters zwischen den Weltkriegen wurde bis vor kurzem keine gebührende Beachtung geschenkt. Dabei geht es um einen Zeitraum, in dem im historischen Stadtkern eine Reihe von Schlüsselgrabungen erfolgten.

Ein großer Teil von ihnen wurde bisher nicht ausgewertet, die Umstände, unter denen die Unternehmungen stattfanden sind meistens unbekannt, und häufig sind noch nicht einmal ihre Dokumentationen verfügbar, die ebenso wie die beweglichen Funde über verschiedene Institutionen verstreut blieben.

Die vorliegende Studie knüpft an die kürzlich veröffentlichte Arbeit von I. Boháčová an, die sich im Rahmen eines neu aufgebauten staatlichen Konzepts der Denkmalpflege erstmals mit der Stellung der Prager Archäologie in der Nachkriegszeit beschäftigte, ferner dann an die von derselben Autorin in Zusammenarbeit mit J. Podliska anschließend erstellten Übersicht der Grabungen und behandelten Themen. Diesmal konzentrieren sich die Verfasser auf die Aspekte der archäologischen Erforschung der Stadt, dank denen man die Zwischenkriegsetappe der Prager Archäologie als Anfang der modernen Archäologie des Mittelalters in Böhmen verstehen kann. In ihrem Rahmen haben sich die ersten bedeutenden Vertreter dieses Fachs profiliert. Aufmerksamkeit wird vor allem zwei Persönlichkeiten entgegengebracht, deren Schlüsselrolle und zweifellos positiver Beitrag für die Archäologie in städtischer Umgebung fast vergessen geblieben sind.

Die erste Persönlichkeit ist R. Hlubinka, ein im Baureferat der Stadt tätig gewesener Jurist und Magistratsbeamter. Er wurde zum Initiator der Tätigkeit des Denkmalbeirats, des im Jahr 1921 gegründeten Beratungsorgans des Prager Magistrats. Der Denkmalbeirat vereinigte in sich Experten aus der Reihe der geisteswissenschaftlichen Fächer, Vertreter des Magistrats und öffentlicher Vereine und verfügte im Bereich der Denkmalpflege in Prag über beträchtliche Kompetenzen. Sein Gestalter war gerade Hlubinka, der mit renommierten Fachleuten und Vertretern der staatlichen Verwaltung für den Bereich Kultur systematisch zusammenarbeitete. Obwohl seiner Ausbildung nach Jurist, verfügte er über umfangreiche Kenntnisse aus den Bereichen Geschichte, Baudenkmäler und auch Archäologie, die er sowohl auf theoretischer, als auch auf praktischer Ebene umsetzte. Der Denkmalbeirat beteiligte sich an der Ausarbeitung der städtischen Regulierungspläne und der Maßnahmen des Magistrats, ebenso an den Vorbereitungsarbeiten von Bauvorhaben und an Bauverfahren. Hlubinka sicherte die Bedingungen für eine systematische Überwachung der Geländearbeiten, für Dokumentation (professionelle Fotodokumentation, Vermessungen), präventive Tätigkeiten sowie für Schutz und Präsentation der Denkmäler. Er beteiligte sich persönlich an der Überwachung einiger Bauvorhaben und Funddokumentationen 
und widmete sich auch der Popularisierung. Über einen langen Zeitraum beschäftigte er sich mit dem Studium des Phänomens der Prager romanischen Häuser und leistete einen bedeutenden Beitrag dazu, Erkenntnisse über sie zu gewinnen (Abb. 8).

Die zweite Persönlichkeit ist Jaroslav Pasternak, ein Archäologe ukrainischer Abstammung, dessen Bedeutung für die Prager Archäologie bisher nicht ausgewertet wurde und dessen Name fast vergessen geblieben ist. Das kann man teilweise darauf zurückführen, dass er nur für kurze Zeit in Prag tätig war (1923-1928), und teilweise auch darauf, dass er nach Abschluss seines Absolutoriums (Doktorat an der Phil. Fak. der Karls-Universität in Prag, 1925) in Prag keine vollwertige fachliche Anstellung erhielt. Jedoch wurde ihm von Anfang an die Aufsicht über bedeutende Geländegrabungen übertragen, was praktisch ihrer tatsächlichen Leitung entsprach. Mit seinem Namen ist vor allem eine der bedeutendsten Prager Grabungen verbunden - die Freilegung des dritten Hofs auf der Prager Burg (1925-1928). Die Grabung erfolgte offiziell unter der Leitung einer institutionsübergreifenden Kommission, an deren Spitze Karel Guth, der Leiter der historisch-archäologischen Abteilung des Nationalmuseums stand. J. Pasternaks Tagebucheintragungen enthalten eine Beschreibung der freigelegten Situationen, einschließlich Vermessungsskizzen. Aus ihnen lässt sich die Methode von Geländearbeiten zuverlässig ableiten. Die Diktion der Eintragungen und auch die erstellte Dokumentation belegen, dass die historischen Gelände nach natürlichen Schichten analysiert wurden. Die Schichten wurden vom Autor mit Buchstaben gekennzeichnet, deren Beschreibungen eine Grundcharakteristik und eine grobe Datierung des Horizontes, dem sie angehörten enthielten, der intuitiv gemäß den jeweils verzeichneten Änderungen im keramischen Inventar festgelegt wurde. Für die einzelnen Horizonte wurden allgemeinverständliche, auf historische Etappen bezogene Begriffe verwendet: „unteres und oberes romanisches Gelände, karolingisches Gelände, Renaissancegelände“, für die auch Daten der absoluten Chronologie angegeben werden. Man kann festhalten, dass sich diese grobe und mehr oder weniger intuitiv festgelegte Chronologie von der heutigen Datierung der keramischen Grundhorizonte nicht sehr unterscheidet, obwohl es in der Zwischenzeit zu gewissen Verschiebungen in der Datierung einiger Keramiktypen gekommen ist. Dabei deuten die Archivalien in der zweiten Hälfte der dreißiger Jahre des 20. Jahrhunderts noch nicht allzu sehr darauf hin, dass eine Grabung nach natürlichen Schichten und die Klärung von Fragen zur Stratigraphie für Pasternaks Weggefährten ein gängiger Bestandteil der Grabungsaktivitäten gewesen wären. Wir wissen nicht, von welchem Vorbild sich Pasternak in dieser Hinsicht hatte inspirieren lassen. Pasternaks ein wenig jüngerer Kollege und Weggefährte Ivan Borkovský, der im Unterschied zu Pasternak in Prag verblieb und letztendlich zur zentralen Persönlichkeit der Prager Archäologie wurde, hatte Mitte der dreißiger Jahre in dieser Hinsicht an Pasternaks Fähigkeiten noch nicht herangereicht. In tschechischer Umgebung wird I. Borkovskýs Ende der dreißiger Jahre erfolgte Grabung im Rosenberg-Palais als Qualitätsumbruch in der Dokumentation von Stratigraphien angesehen.

Die Verfasser beschäftigen sich ferner mit Fragen zur Organisation der Rettungsgrabung der Stadt unter den Bedingungen der damals neugeformten Staats- und Munizipalverwaltung, mit deren Aufbau auch eine intensive Bautätigkeit im historischen Stadtkern verbunden war, und zwar in einer Situation, als das Referat über nicht genügend erfahrene Fachleute verfügte. Die nachrückende Archäologengeneration hatte in den zwanziger Jahren erst ihr Studium abgeschlossen und wurde bei den Grabungen als freiwillige Kräfte hinzugezogen. Der Mangel an fachlichen Kapazitäten und Finanzmitteln führte einerseits zu einer begrenzten Anzahl an Grabungen, andererseits zu einer systematischen Beobachtung und Inspizierung solcher Stellen, an denen man bedeutende Funde erwarten konnte. Gerade in jener Zeit erfolgten die ersten ausgedehnteren Grabungen noch vor den Bauarbeiten im Stadtzentrum außerhalb der Prager Burg und des Vyšehrad. Wachsam beobachtet wurden vor allem Orte, an denen potenziell historische Objekte wie mittelalterliche Stadtbefestigungen, untergegangene Sakralbauten sowie städtische Bebauung vorkamen. Außerhalb des historischen Stadtkerns erfolgte eine der ersten Grabungen einer Burgarchitektur auf der Wenzelsburg (Nový hrad) in Kunratice, die während den Hussitenkriegen unterging. Die 
meisten Grabungen erfolgten im Rahmen der gegebenen, hinsichtlich der Zusammenarbeit von mehreren Institutionen begrenzten Möglichkeiten. Die Grabungsleitung auf der Prager Burg und dem Vyšehrad unterstand den dazu gegründeten institutionsübergreifenden Kommissionen, die Vorhaben in der Stadt durchweg dem Denkmalbeirat. Unübersehbares Ergebnis der beschriebenen Aktivitäten sind mehrere archäologische Areale, in denen freigelegte Denkmäler in situ erhalten wurden. Die vielversprechende Entwicklung des Faches wurde durch die Wirtschaftskrise der dreißiger Jahre und durch die anschließende gesellschaftliche, vom Kriegskonflikt mit all seinen vernichtenden Folgen beendete Entwicklung unterbrochen.

An das in sich geschlossene Zwischenkriegskonzept der Erforschung archäologischer Denkmäler und deren Schutz tun wir heute in vielerlei Hinsicht anknüpfen. Der archäologische Bestand und das von den Grabungen aus der Zwischenkriegszeit stammende Archivmaterial, das vor allem im Bestand des Archivs der Hauptstadt Prag, aber auch in einer Reihe weiterer Institutionen erhalten geblieben ist, sind für das heutige Studium der Entstehung und Entwicklung Prags häufig von Schlüsselbedeutung und demnach unentbehrlich.

PhDr. Ivana Boháčová, Ph.D., Archeologický ústav AV ČR, Praha, v. v. i., Letenská 4, 11801 Praha 1, Česká republika,bohacova@arup.cas.cz

PhDr. Jaroslav Podliska, Ph.D., Národní památkový ústav, územní odborné pracoviště v Praze, Na Perštýně 356/12, 11000 Praha 1, Česká republika,podliska.jaroslav@npu.cz 